In cooperation with the Southern Division Naval Facilities Engineering Command

\title{
Chemical Quality of Water, Sediment, and Fish in Mountain Creek Lake, Dallas, Texas, 1994-97
}

Water-Resources Investigations Report 03-4082 
U.S. Department of the Interior

U.S. Geological Survey

\section{Chemical Quality of Water, Sediment, and Fish in Mountain Creek Lake, Dallas, Texas, 1994-97}

By P.C. Van Metre, S.A. Jones, J. Bruce Moring, B.J. Mahler, and Jennifer T. Wilson

\section{U.S. GEOLOGICAL SURVEY}

Water-Resources Investigations Report 03-4082

In cooperation with the Southern Division Naval Facilities Engineering Command 


\section{U.S. DEPARTMENT OF THE INTERIOR}

Gale A. Norton, Secretary

\section{U.S. GEOLOGICAL SURVEY}

Charles G. Groat, Director

Any use of trade, product, or firm names is for descriptive purposes only and does not imply endorsement by the U.S. Government.

For additional information write to

\section{District Chief}

U.S. Geological Survey

8027 Exchange Dr.

Austin, TX 78754-4733

E-mail: dc_tx@usgs.gov

Copies of this report can be purchased from

U.S. Geological Survey

Information Services

Box 25286

Denver, CO 80225-0286

E-mail: infoservices@usgs.gov 


\section{CONTENTS}

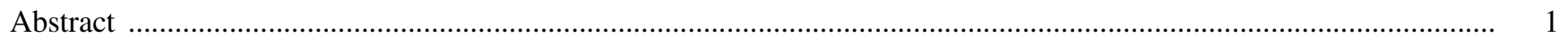

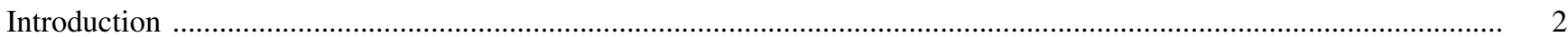

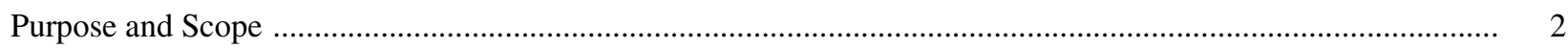

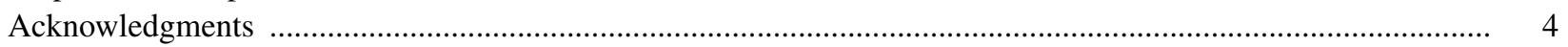

Methods

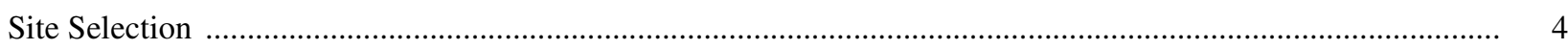

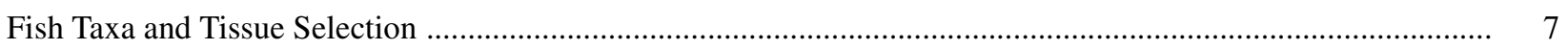

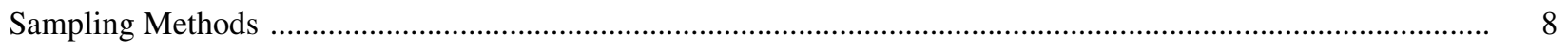

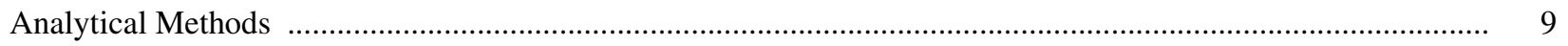

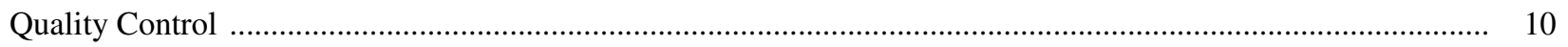

Potential Sources of Contamination From Navy Facilities to Mountain Creek Lake ................................................... 12

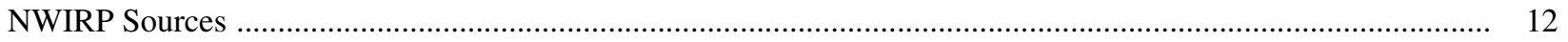

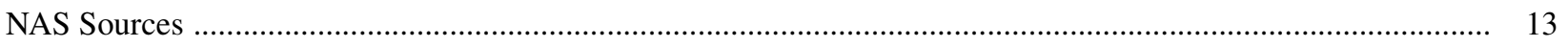

Chemical Quality of Water, Sediment, and Fish in Mountain Creek Lake ............................................................. 15

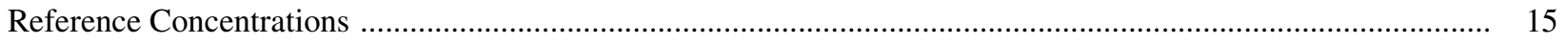

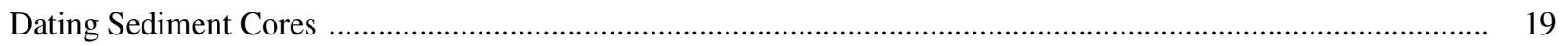

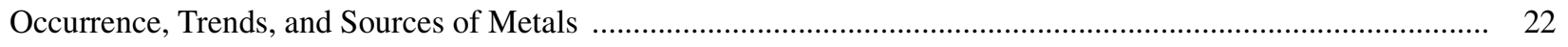

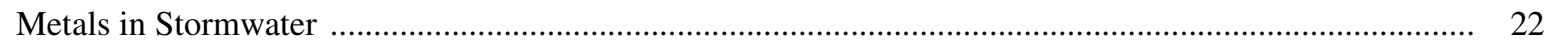

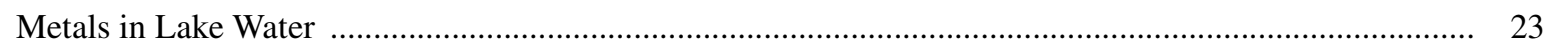

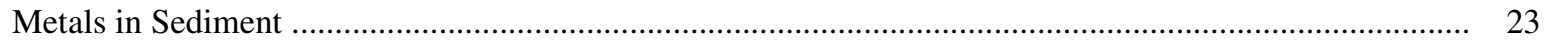

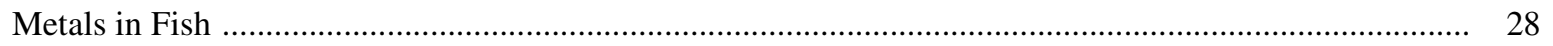

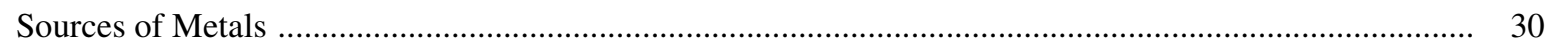

Occurrence, Trends, and Sources of Volatile Organic Compounds ................................................................ 33

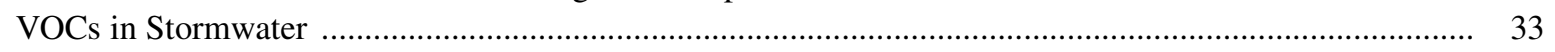

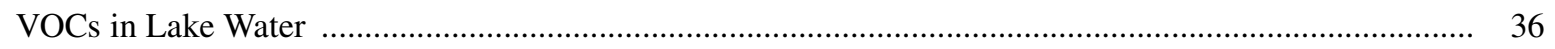

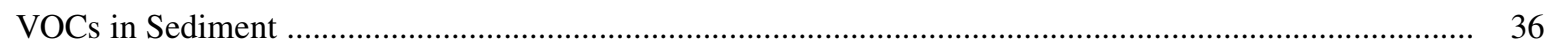

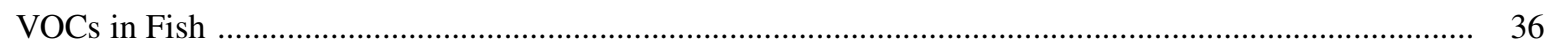

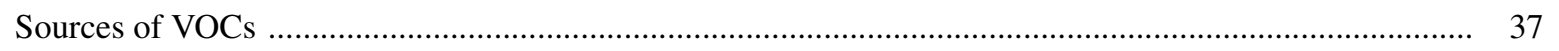

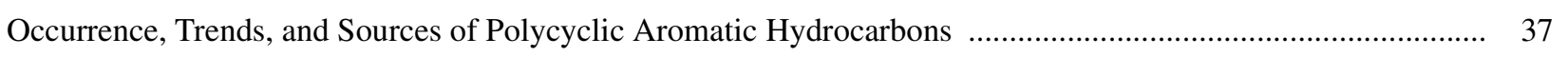

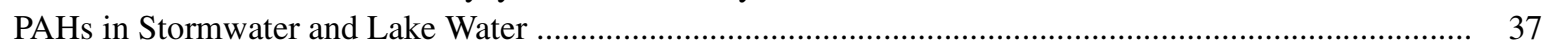

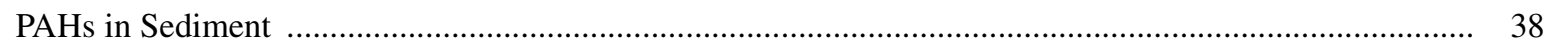

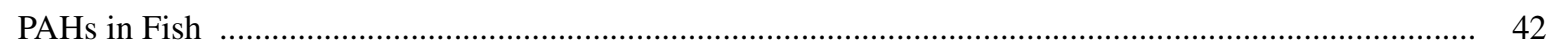

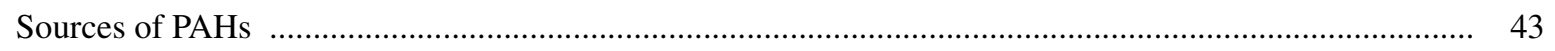

Pyrogenic Versus Uncombusted Fuel Sources . .................................................................... 43

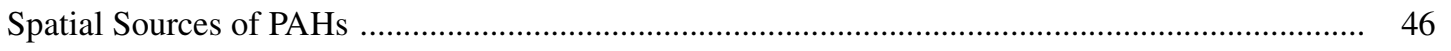

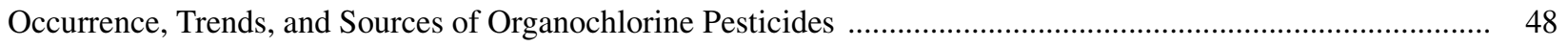

Organochlorine Pesticides in Stormwater and Lake Water ......................................................... 48

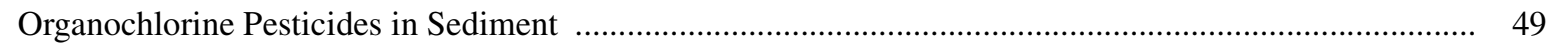

Organochlorine Pesticides in Fish ............................................................................................... 50

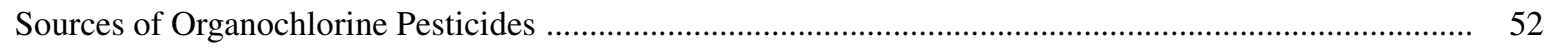

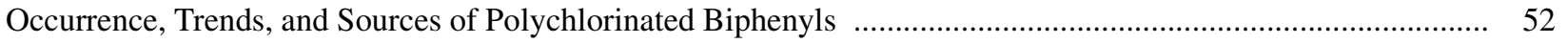

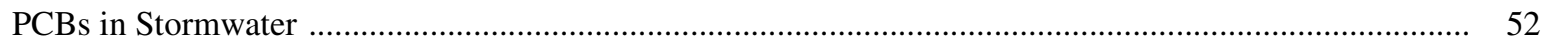

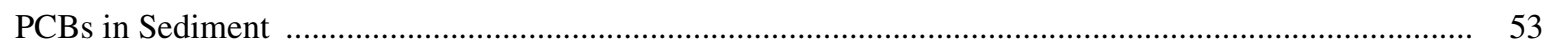

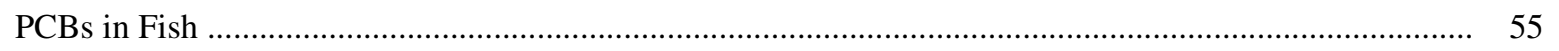

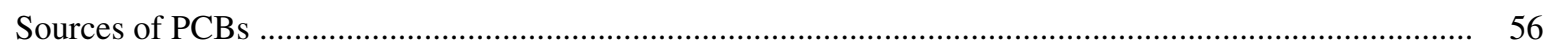

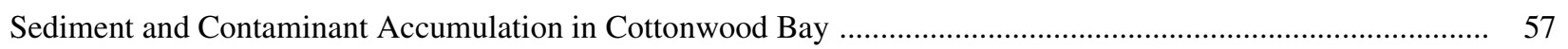

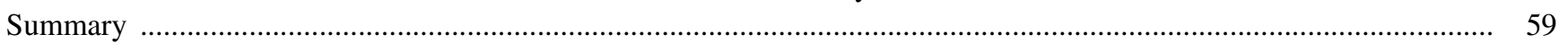

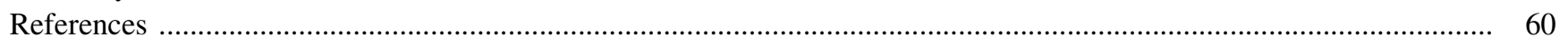




\section{FIGURES}

1-2. Maps showing:

1. Locations of Phase I sampling sites and media collected at Mountain Creek Lake, Dallas, Texas ........... 3

2. Locations of Phase II sampling sites and media collected at Mountain Creek Lake, Dallas, Texas ......... 5

3-5. Boxplots showing:

3. Percent recovery of laboratory spiked quality-control samples for polycyclic aromatic hydrocarbons in bottom sediment collected at Mountain Creek Lake, Dallas, Texas

4. Percent differences between environmental and replicate samples in lake bottom sediment collected at Mountain Creek Lake, Dallas, Texas

5. Percent recovery of laboratory spiked quality-control samples for organochlorine pesticides in fish tissue collected at Mountain Creek Lake, Dallas, Texas

6-8. Maps showing:

6. Locations of selected buildings, groups, and solid-waste management units (SWMUs) on the Naval Air Station and Naval Weapons Industrial Reserve Plant, Dallas, Texas

7. Place names of parts of Mountain Creek Lake used in this report ....................................................... 16

8. Locations of sites and range in selected constituents in bottom sediments for clusters .......................... 18

9. Graphs showing cesium- 137 and organochlorine pesticide concentrations in M2.40 and MCL -4 cores ........... 20

10. Graphs showing age-depth indicators in Bay-13 core ......................................................................... 21

11-15. Graphs showing:

11. Ratios of Phase I metal concentrations in lake bottom sediment at selected sites to mean concentrations of main-lake reference sites

12. Ratios of Phase II metal concentrations in lake bottom sediment at selected sites to mean concentrations of main-lake reference sites

13. Trends in chromium, lead, and zinc concentrations in MCL-4, M2.40, and Bay-13 cores .................... 27

14. Trends in heavy metals concentrations in Cottonwood Bay as indicated by the Bay-13 core ................. 29

15. Trends in mercury concentrations in the NAS inlet as indicated by the M2.40 core ............................... 30

16. Boxplots showing distribution of metal concentrations in fish tissues, Mountain Creek Lake ......................... 31

17. Graphs showing ratios of lake-bottom sediment and suspended sediment metal concentrations in the west lagoon and Cottonwood Bay to mean concentrations of mean-lake reference sites

18. Graph showing percent detections of volatile organic compounds in composite samples collected at the fixed stormwater sites, Naval Air Station and Naval Weapons Industrial Reserve Plant

19. Boxplots showing distribution of BTEX compound concentrations detected at NAS-2 stormwater site

20. Graphs showing volatile organic compound concentrations in lake water samples

21. Maps showing fluoranthene concentrations in top 3 centimeters of lake bottom sediments from (a) Phase I sampling; (b) Phase II sampling; (c) Phase II Cottonwood Bay sampling; and (d) Phase II NAS inlet sampling

22. Map showing total PAH concentrations in top 3 centimeters of surficial sediment from Phase II sampling

23. Boxplots showing distribution of benzo $(a)$ pyrene and benzo $(b)$ fluoranthene concentrations in top 3 centimeters of surficial sediment

24. Graphs showing trends in PAH concentrations in Bay-13, MCL-7, and MCL -4 cores

25. Graphs showing trends in PAH concentrations in M2.40 core in the NAS inlet

26. Boxplots showing longitudinal variation in total PAH and source indicator ratios for surficial sediment samples

27. Boxplots showing comparison of lake-bottom sediment and suspended sediment PAH concentrations in the east and west lagoons and Cottonwood Bay

28. Graphs showing mean concentrations of organochlorine pesticides detected in composite fish tissues sampled in Phase I

29. Boxplots showing distribution of organochlorine pesticide concentrations detected in fish sampled in Phase II 
30. Maps showing PCB concentrations in top 3 centimeters of lake bottom sediment from (a) Phase I sampling; (b) Phase II sampling; (c) Phase II Cottonwood Bay sampling; and (d) Phase II NAS inlet sampling

31. Graphs showing trends in PCB concentrations in Mountain Creek Lake (cores MCL-4, M2.40, Bay-13) and in White Rock Lake, Dallas Texas

32. Boxplots showing distribution of PCB concentrations in fish tissues

33. Map showing thickness of lacustrine sediment in central and east Cottonwood Bay

34. Graphs showing mass accumulation rates of silver in Bay-13 core

\section{TABLES}

1. Type and number of samples analyzed for selected constituents at Mountain Creek Lake, Dallas, Texas

2. Results of fishing-habits survey on Mountain Creek Lake

3. Waste disposed of in the West Lagoon Naval Weapons Industrial Reserve Plant ........................................... 13

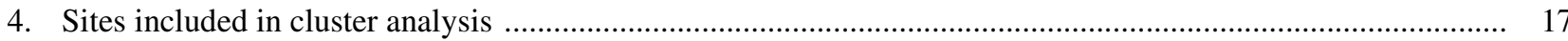

5. Summary of selected metal concentrations in sediment ............................................................ 28

6. Comparison of volatile organic compound concentrations at the Navy sites, Dallas, Texas, and at industrial sites in the Dallas-Fort Worth area

7. Polycyclic aromatic hydrocarbon concentrations in stormwater suspended sediment samples

8. Diagnostic polycyclic aromatic hydrocarbon ratios for selected surficial sediment samples

9. Reported and estimated total polycyclic aromatic hydrocarbon concentrations for east and west lagoon sediment

10. Organochlorine pesticide and polychlorinated biphenyl concentrations in stormwater suspended sediment samples

11. Summary of total polychlorinated biphenyl concentrations in sediment

12. Estimated total and annual contaminant mass accumulations in east and central Cottonwood Bay 


\title{
Chemical Quality of Water, Sediment, and Fish in Mountain Creek Lake, Dallas, Texas, 1994-97
}

\author{
By P.C. Van Metre, S.A. Jones, J. Bruce Moring, B.J. Mahler, and Jennifer T. Wilson
}

\section{Abstract}

The occurrence, trends, and sources of numerous inorganic and organic contaminants were evaluated in Mountain Creek Lake, a reservoir in Dallas, Texas. The study, done in cooperation with the Southern Division Naval Facilities Engineering Command, was prompted by the Navy's concern for potential off-site migration of contaminants from two facilities on the shore of Mountain Creek Lake, the Naval Air Station Dallas and the Naval Weapons Industrial Reserve Plant. Sampling of stormwater (including suspended sediment), lake water, bottom sediment (including streambed sediment), and fish was primarily in Mountain Creek Lake but also was in stormwater outfalls from the Navy facilities, nearby urban streams, and small streams draining the Air Station.

Volatile organic compounds, predominantly solvents from the Reserve Plant and fuel-related compounds from the Air Station, were detected in stormwater from both Navy facilities. Fuel-related compounds also were detected in Mountain Creek Lake at two locations, one near the Air Station inlet where stormwater from a part of the Air Station enters the lake and one at the center of the lake. Concentrations of volatile organic compounds at the two lake sites were small, all less than 5 micrograms per liter.

Elevated concentrations of cadmium, chromium, copper, lead, mercury, nickel, silver, and zinc, from 2 to 4 times concentrations at background sites and urban reference sites, were detected in surficial bottom sediments in Cottonwood Bay, near stormwater outfalls from the Reserve Plant.
Elevated concentrations of polycyclic aromatic hydrocarbons and polychlorinated biphenyls, compared to background and urban reference sites, were detected in surficial sediments in Cottonwood Bay. Elevated concentrations of polycyclic aromatic hydrocarbons, indicative of urban sources, also were detected in Cottonwood Creek, which drains an urbanized area apart from the Navy facilities. Elevated concentrations of polychlorinated biphenyls were detected in two inlets near the Air Station shoreline. Polycyclic aromatic hydrocarbon and heavy metal concentrations near the Air Station shoreline were not elevated compared to urban reference sites.

Much larger concentrations of selected heavy metals, polycyclic aromatic hydrocarbons, and polychlorinated biphenyls were detected in deeper, older sediments than in surficial sediments in Cottonwood Bay. The decreases in concentrations coincide with changes in wastewater discharge practices at the Reserve Plant. Elevated concentrations of polycyclic aromatic hydrocarbons and polychlorinated biphenyls also were detected in older sediments in the Air Station inlet.

On the basis of dated sediment cores and contaminant discharge histories, contaminant accumulation rates in Cottonwood Bay were much greater historically than recently. Most heavy metals, polycyclic aromatic hydrocarbons, and polychlorinated biphenyls that accumulated in the central and eastern parts of Cottonwood Bay appear to have come from the west lagoon on the Reserve Plant. Treated sewage and industrialprocess wastewater were discharged to the west lagoon from about 1941 to 1974. Estimated annual contaminant accumulation rates in Cottonwood Bay decreased by from 1 to 2 orders of magnitude 
after 1974, when most point-source discharges to the west lagoon ceased.

Polychlorinated biphenyls were detected in 61 of 62 individual fish-tissue samples. The largest average concentrations were in eviscerated channel catfish and the smallest were in largemouth bass fillets. Polychlorinated biphenyl and selenium concentrations from analyses of this study were large enough to prompt the Texas State Department of Health to issue a fish-possession ban for Mountain Creek Lake in 1996.

Suspended sediments in stormwater at the lagoon outfalls and at sites on Cottonwood Creek were sampled and analyzed for major and trace elements, polycyclic aromatic hydrocarbons, organochlorine pesticides, and polychlorinated biphenyls. The suspended sediments from the outfalls contained about the same mixture of heavy metals and organic compounds, in elevated concentrations compared to reference sites, as bottom sediments from the lagoons and surficial bottom sediments in Cottonwood Bay.

Diagnostic ratios of polycyclic aromatic hydrocarbons indicate that uncombusted fuel sources contribute to older sediments and that pyrogenic sources of polycyclic aromatic hydrocarbons dominate recently deposited sediments in Cottonwood Bay and along the Air Station shoreline.

\section{INTRODUCTION}

Mountain Creek Lake is a reservoir on Mountain Creek in the southwestern part of Dallas, Tex. (fig. 1). The lake, impounded in 1929, is about 5 kilometers (km) long, $2 \mathrm{~km}$ wide, and about 7 meters $(\mathrm{m})$ deep at the deepest point. The lake is owned by Texas Utilities, which uses the lake as a cooling reservoir for its oilfired electrical-power generating plant on the northeast shore. The lake is not used for water supply but is considered a potential water supply for the State of Texas and is used for recreation, including fishing. Two facilities of the U.S. Department of the Navy are on the northwestern shore of Mountain Creek Lake, the Naval Air Station Dallas (NAS) and the Naval Weapons Industrial Reserve Plant (NWIRP). As of 1998, a Resource Conservation and Recovery Act (RCRA) Facility Investigation (RFI) was being conducted at
NWIRP and NAS, and base closure was underway at NAS (EnSafe/Allen \& Hoshall, 1996a, b; 1997a, b).

The NAS was established in 1928 as Hensley Field and has been expanded several times since. Major expansion occurred during World War II, and by 1945 more than 4,000 personnel were stationed there. During 1949-50 the main north-south runway was expanded on fill that separated Cottonwood Bay, a narrow arm of the lake at the mouth of Cottonwood Creek, from the main body of the lake. A canal connecting Cottonwood Bay to the lake was completed at that time to allow outflow from the Cottonwood Creek drainage. Cottonwood Bay is a part of Mountain Creek Lake.

The NWIRP opened in 1941 as North American Aviation and remains an airplane manufacturing facility today. It is currently (1998) operated by Northrup Grumman.

In 1994, the U.S. Geological Survey (USGS), in cooperation with the Southern Division Naval Facilities Engineering Command, began a study to address the possibility of contamination in Mountain Creek Lake. The objective was to determine the occurrence and distribution of contaminants in Mountain Creek Lake. The information could be useful for indicating the potential for continuing contamination by stormwater runoff from either NAS or NWIRP and for evaluating humanhealth risks from consumption of fish from the lake.

Because this investigation focused on the Navy facilities, more detailed definition of contaminant occurrence was obtained near the Navy facilities than in other areas of the lake. Furthermore, the work of the Navy and its contractors has resulted in a better understanding of occurrence and historical releases of contaminants on the Navy facilities than on other areas in the Mountain Creek Lake watershed. A detailed description of the occurrence and sources of all contaminants in all parts of the lake was not an objective of this investigation, although the objectives included defining the extent of contamination from the Navy facilities. To define the extent, sediments in the middle and upper parts of the lake and in the streambed and suspended sediments in Cottonwood Creek were sampled.

\section{Purpose and Scope}

This report presents findings of the USGS study of Mountain Creek Lake and selected small tributaries and streams draining the Navy facilities. Specifically, the report presents and discusses the occurrence of all constituents analyzed for by compound or element 


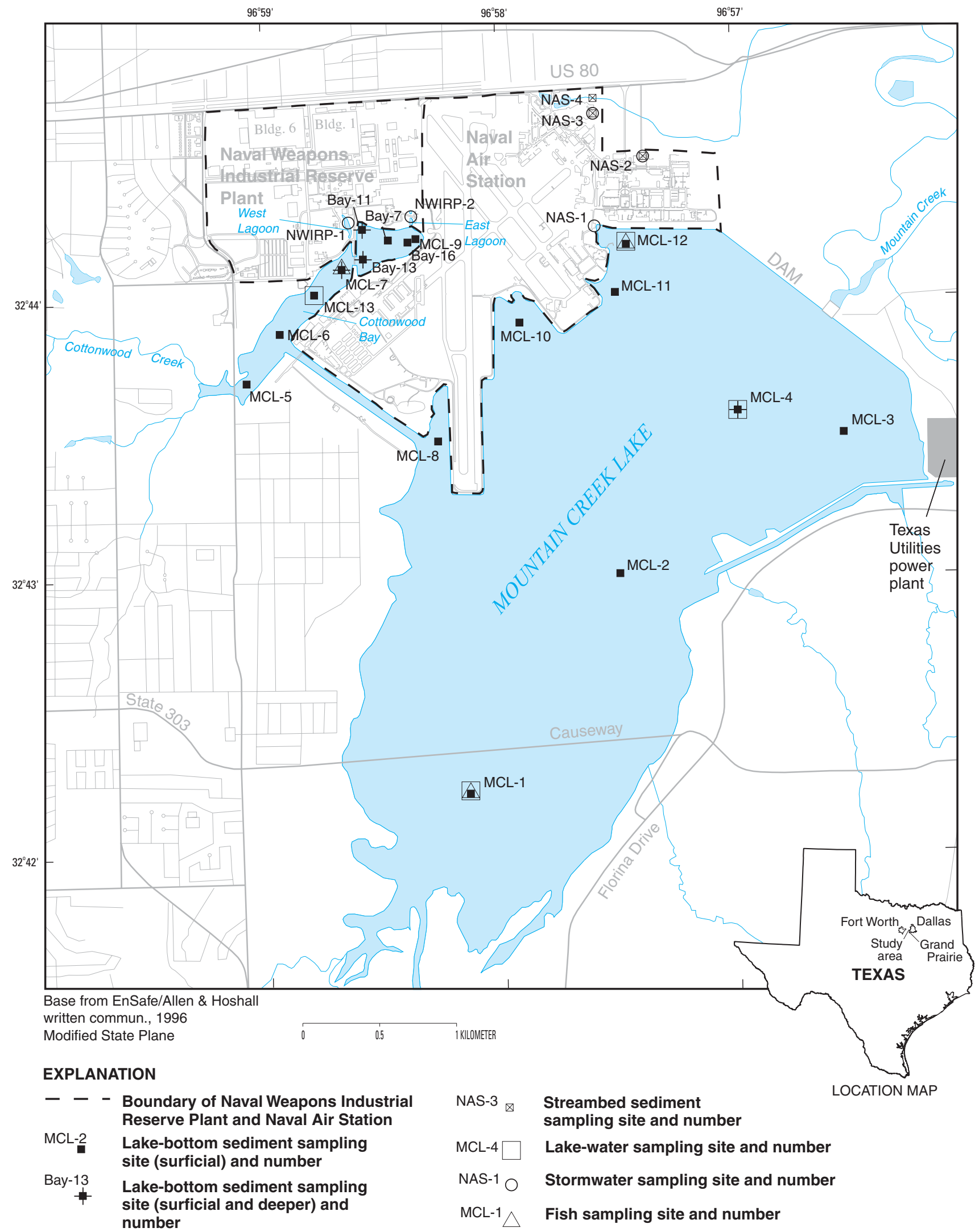

Figure 1. Locations of Phase I sampling sites and media collected at Mountain Creek Lake, Dallas, Texas. 
group in each of the environmental phases sampled (stormwater [includes suspended sediment], lake water, bottom sediment [includes streambed sediment], and fish). On the basis of occurrence, selected contaminants are evaluated further. These evaluations include identification of temporal trends, estimation of mass fluxes, and identification of probable contaminant sources.

Trends are identified using age-dated bottom-sediment cores. Mass fluxes are estimated using data from sediment cores, a sedimentation survey, and stormwater sampling. Probable sources are identified on the basis of (1) identification of a potential source or sources outside the lake, either in the urbanized parts of the watershed or on the Navy facilities; (2) description of a plausible transport pathway from the outside source(s) to the lake, and (3) relation of the source and pathway to the spatial and temporal distribution in the lake. Additionally, in the case of some groups of related organic compounds, chemical "signatures" are used to aid in source identification.

Data collected in this study for lake water, bottom sediment, and fish are presented in Jones and others (1997). Also included in that report are descriptions of the sampling design, collection methods (except for suspended sediment), and laboratory analytical methods. Stormwater data and loads of selected potential contaminants are presented in Raines and others (1997). Datacollection methods and analytical results for suspended sediment are presented in this report.

\section{Acknowledgments}

The authors acknowledge the cooperation and assistance of EnSafe (formerly EnSafe/Allen \& Hoshall), the Navy's private consultant on the project. EnSafe provided its on-site facilities for USGS use and made all data previously collected during the RFI available to the USGS. The cooperation of personnel from the U.S. Navy and from Northrup Grumman also is acknowledged.

\section{METHODS}

Most methods of this study are described in Jones and others (1997) and Raines and others (1997) and are summarized briefly here. Methods for collection of suspended sediment samples are presented in more detail here because they are not included in the other reports. Details of a USGS-conducted fishing survey that contributed to the fish sampling approach also are presented here.
The study design, site selection, sampling and analytical methods, and quality-assurance procedures are described in a Sampling and Analysis Plan (SAP) provided to the Navy before sample collection (U.S. Geological Survey, written commun., 1995). Except where noted here, methods follow those described in the SAP.

\section{Site Selection}

The study was done in two phases (table 1). During Phase I (fig. 1), stormwater was sampled at five sites; lake water was sampled at four sites; lake bottom sediment was sampled at 17 sites; streambed sediment was sampled at three sites; and fish were sampled at three sites in the lake. During Phase II of the study (fig. 2), suspended sediment in stormwater was sampled at four sites; lake bottom sediment was sampled at 44 sites; streambed sediment was sampled at four sites; and fish were sampled in 11 areas of the lake.

The five stormwater sampling sites established during Phase I-three on NAS and two on NWIRP (fig. 1) -were located to measure runoff from most of NWIRP and from the most developed parts of NAS.

The four lake-water sampling sites (fig. 1) established during Phase I were located to measure water quality in areas near the two Navy facilities, in the main body of the lake, and at a reference site. Sites were colocated with sediment and fish sampling sites, where possible, to provide information on all three media at these locations.

The 17 lake-bottom sediment sampling sites established during Phase I (fig. 1) were selected to broadly cover the entire lake, including Cottonwood Bay, but to be more closely spaced near the Navy facilities. The selection of each sampling site for surficial (uppermost 3 centimeters [cm]) sediments was based on the results of reconnaissance sedimentcore sampling and on an understanding of sedimentation processes in reservoirs. Thirteen sites were located near potential contamination sources identified on NAS and NWIRP or near major stormwater outfalls from NAS and NWIRP to the lake. The four other lake sites were located in the main body of the lake. Three of the lake-bottom sediment sites were selected for sampling of deeper, older sediments in the lake for analysis of major and trace elements and hydrophobic organic compounds (fig. 1). Sediment pore water from deeper sediments also was analyzed for volatile organic compounds (VOCs) in a reconnaissance sampling of 


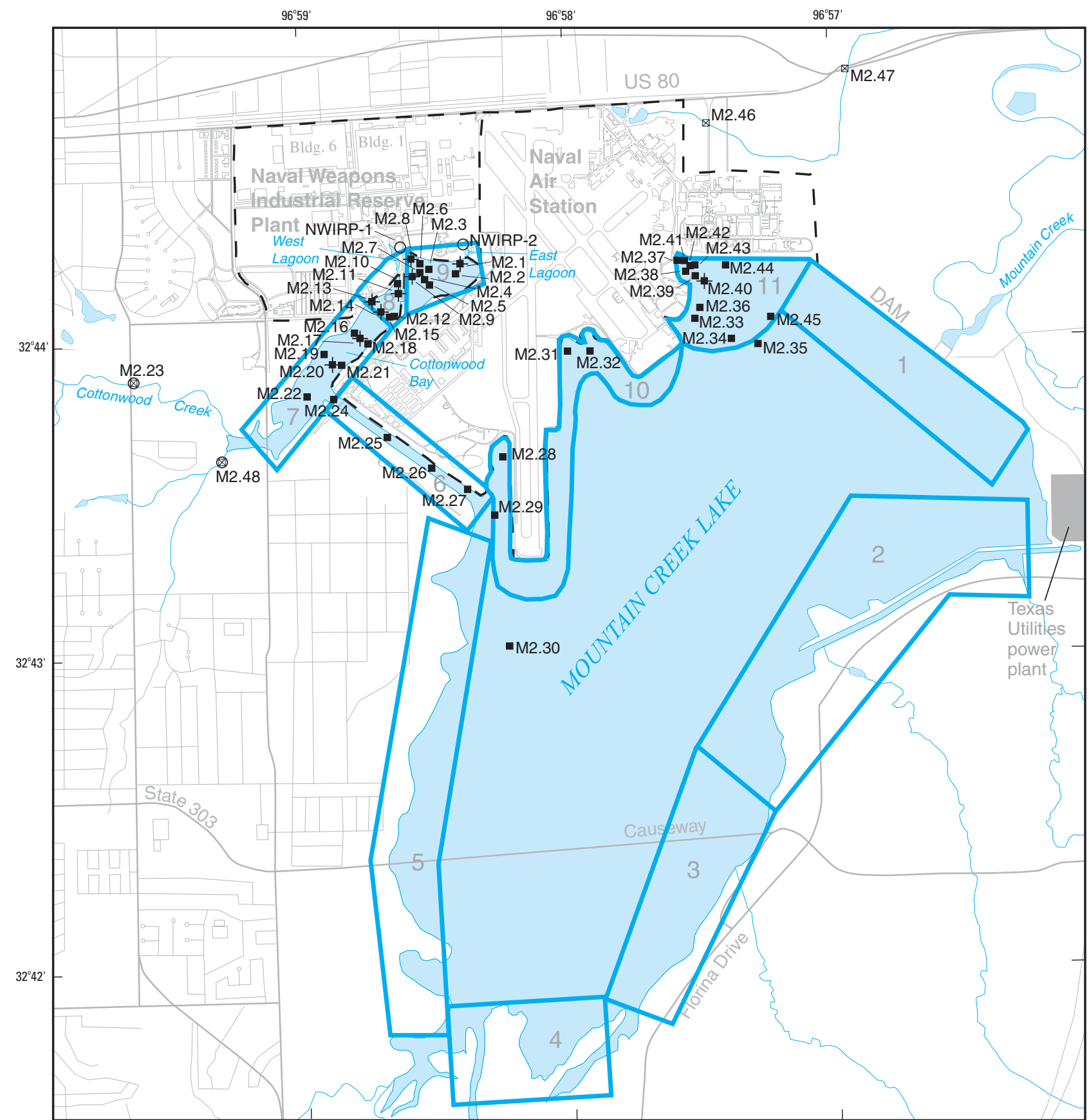

Base from EnSafe/Allen \& Hoshall written commun., 1996 Modified State Plane

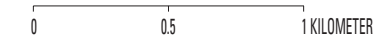

\section{EXPLANATION}

\begin{tabular}{|c|c|}
\hline 3 & Fish sampling area and number \\
\hline- - & $\begin{array}{l}\text { Boundary of Naval Weapons Industrial } \\
\text { Reserve Plant and Naval Air Station }\end{array}$ \\
\hline M2.30 & $\begin{array}{l}\text { Lake-bottom sediment sampling } \\
\text { site (surficial) and number }\end{array}$ \\
\hline
\end{tabular}

$$
\begin{array}{cl}
\text { M2.11 } & \begin{array}{l}
\text { Lake-bottom sediment sampling } \\
\text { site (surficial and deeper) and } \\
\text { number }
\end{array} \\
\text { M2.46 } & \begin{array}{l}
\text { Streambed sediment sampling } \\
\text { site and number }
\end{array} \\
\text { NWIRP-1 } & \begin{array}{l}
\text { Suspended sediment sampling } \\
\text { site and number }
\end{array}
\end{array}
$$

Figure 2. Locations of Phase II sampling sites and media collected at Mountain Creek Lake, Dallas, Texas. 
Table 1. Type and number of samples analyzed for selected constituents at Mountain Creek Lake, Dallas, Texas $[--$, not analyzed $]$

\begin{tabular}{|c|c|c|c|c|c|c|c|c|}
\hline \multirow[b]{2}{*}{$\begin{array}{l}\text { Type of sample } \\
\text { (no. of sites/areas) }\end{array}$} & \multicolumn{8}{|c|}{ Constituent or property and no. of samples analyzed } \\
\hline & $\begin{array}{c}\text { Volatile } \\
\text { organic } \\
\text { com- } \\
\text { pounds }\end{array}$ & $\begin{array}{c}\text { Semi- } \\
\text { volatile } \\
\text { organic } \\
\text { com- } \\
\text { pounds }\end{array}$ & $\begin{array}{c}\text { Polycyclic } \\
\text { aromatic } \\
\text { hydro- } \\
\text { carbons }\end{array}$ & $\begin{array}{l}\text { Organo- } \\
\text { chlorine } \\
\text { pesticides }\end{array}$ & $\begin{array}{l}\text { Polychlori- } \\
\text { nated } \\
\text { biphenyls }\end{array}$ & $\begin{array}{c}\text { Trace } \\
\text { elements }\end{array}$ & $\begin{array}{l}\text { Cesium- } \\
137\end{array}$ & $\begin{array}{c}\text { Grain } \\
\text { size }\end{array}$ \\
\hline \multicolumn{9}{|c|}{ Phase I } \\
\hline Stormwater (5 sites) & 68 & 30 & -- & 30 & 30 & 68 & -- & -- \\
\hline Lake water (4 sites) & 4 & -- & -- & 4 & -- & 4 & -- & -- \\
\hline Lake bottom sediment (17 sites) & 8 & 28 & -- & 41 & 41 & 79 & 23 & 80 \\
\hline Streambed sediment ( 3 sites) & -- & 3 & -- & 3 & 3 & -- & -- & 3 \\
\hline Fish tissue (3 sites) & -- & -- & -- & 6 & 6 & 6 & -- & -- \\
\hline \multicolumn{9}{|c|}{ Phase II } \\
\hline $\begin{array}{l}\text { Suspended sediment in storm- } \\
\text { water ( } 4 \text { sites) }\end{array}$ & -- & -- & 6 & 6 & 6 & 11 & -- & -- \\
\hline Lake bottom sediment (44 sites) & -- & -- & 73 & 21 & 73 & 77 & 12 & 70 \\
\hline Streambed sediment (4 sites) & -- & -- & 4 & 4 & 4 & -- & -- & -- \\
\hline Fish tissue (11 areas) & 5 & 5 & -- & 62 & 62 & 45 & -- & -- \\
\hline
\end{tabular}

several sites in Cottonwood Bay (Jones and other, 1997).

The three streambed sediment sampling sites established during Phase I near the NAS property boundary (fig. 1) were selected to determine chemical characteristics of bottom sediments in streams draining the facility. All three drainages contain possible contamination sources identified on the facility by EnSafe; however, all three drain to Mountain Creek downstream from Mountain Creek Lake and thus do not contribute flow to the lake.

The three fish sampling sites established during Phase I (fig. 1) were coincident with lakebottom sediment and lake-water sampling sites to help define the distribution of contaminants among media. Two sites were selected to measure potential contamination near the Navy facilities, and the third site was selected to describe background conditions in the lake; however, because of their mobility, fish from all parts of the lake could be affected by localized presence of contaminants.

Four suspended sediment sampling sites were established during Phase II (fig. 2). Two of the four were new sites on Cottonwood Creek (one on the north fork, one on the south fork) selected to determine if hydrophobic contaminants from off-site urban areas were entering Mountain Creek Lake from Cottonwood Creek. The other two suspended sediment sampling sites, coincident with the two Phase I NWIRP stormwater sampling sites, were selected to determine if hydrophobic contaminants were entering the lake via runoff from NWIRP.

During Phase II, 44 additional lake-bottom sediment sampling sites (fig. 2) were established to enhance knowledge of the spatial and temporal distribution of contaminants in areas where contamination was found during Phase I and to help identify sources of bottom-sediment contamination. Eight of the 44 sites, each in Cottonwood Bay, were selected for sampling one or two deeper layers of sediment, and one site, M2.40, had numerous deeper layers analyzed to provide detailed contaminant trend information. Four streambed sediment sampling sites also were established (fig. 2).

Phase II fish sampling areas (fig. 2) were selected to represent the entire range in expected contaminant concentrations in the lake and on the basis of the results of a fishing-habits survey described in the next section. 
Table 2. Results of fishing-habits survey on Mountain Creek Lake

\begin{tabular}{lccccc}
\hline Species & $\begin{array}{c}\text { Fraction of all fish } \\
\text { caught represented } \\
\text { by particular species } \\
\text { (percent) }\end{array}$ & $\begin{array}{c}\text { Fraction of all fish } \\
\text { eaten represented by } \\
\text { particular species } \\
\text { (percent) }\end{array}$ & \multicolumn{3}{c}{$\begin{array}{c}\text { Fraction of particular species } \\
\text { eaten prepared as: }\end{array}$} \\
\cline { 5 - 7 } & 16 & 17 & $\begin{array}{c}\text { Fillet } \\
\text { skin-off } \\
\text { (percent) }\end{array}$ & $\begin{array}{c}\text { Eviscerated } \\
\text { skin-on } \\
\text { (percent) }\end{array}$ & $\begin{array}{c}\text { whole fish } \\
\text { (percent) }\end{array}$ \\
\hline Channel catfish & 14 & 15 & 60 & 34 & 5.7 \\
Blue catfish & 12 & 14 & 60 & 33 & 6.6 \\
White crappie & 12 & 13 & 46 & 43 & 11 \\
Yellow catfish & 11 & 11 & 50 & 38 & 12 \\
White bass & 10 & 11 & 57 & 33 & 9.5 \\
Bullhead catfish & 10 & 10 & 57 & 38 & 4.8 \\
Largemouth bass & 7.4 & 6.0 & 52 & 37 & 11 \\
Freshwater drum & 3.6 & 1.0 & 45 & 27 & 27 \\
Common carp & 3.2 & 1.0 & 100 & 0 & 0 \\
Sunfish species & 1.2 & 1.0 & 0 & 50 & 50 \\
Smallmouth buffalo & 10 & 50 & 50 & 0 \\
\hline
\end{tabular}

Note: Sum of fractions of all fish or of particular species might not equal 100 percent because of rounding.

\section{Fish Taxa and Tissue Selection}

Decisions on which fish taxa and tissue to sample were made on the basis of a survey of the habits of the lake fishermen. The survey was made over three consecutive Saturdays and one Friday in April and early May 1995. The full perimeter of the lake was visited three times each day by boat and vehicle approximately from sunrise until late morning, from early afternoon until mid-afternoon, and from late evening until onehalf hour after sunset. The 81 fishermen contacted during the survey were mostly from Dallas and surrounding communities.

Information on fish caught and consumed and on the nature of preparation was gathered in the survey (table 2). Channel catfish were the most frequently caught and the most frequently eaten. On average, about 52 percent of fillets eaten were skin-off and about 35 percent eaten were skin-on. Skin-off fillets were consumed more frequently than skin-on fillets for every species except sunfish. Sunfish and freshwater drum were the most frequently consumed eviscerated whole fish. On average, about 13 percent of fish eaten were eviscerated whole fish.

Of the 81 fishermen surveyed, 51 (63 percent) said they fished most frequently in area 2, adjacent to the Texas Utilities power plant (fig. 2). Eleven (14 percent) fished most frequently in area 11 near NAS. Eight
(10 percent) fished mostly in area 7 in the west end of Cottonwood Bay. Three (4 percent) indicated that their favorite fishing area was along the southeastern shoreline of the lake (area 3). Seventy-three (90 percent) of the 81 fishermen were bank fishermen, and eight (10 percent) were boat fishermen. The majority of the boat fishermen interviewed said they usually release all the fish they catch.

On the basis of the results of the survey and of fish habits, channel catfish (Ictalurus punctatus), largemouth bass (Micropterus salmoides), and common carp (Cyprinus carpio) were selected as target taxa. The most frequently caught and consumed species was the channel catfish, which is abundant throughout the lake. Largemouth bass were caught and consumed less frequently than various catfish and white crappie; however, largemouth bass were selected because of their more localized feeding and spawning habits thus providing more site-specific information on contaminants. Common carp were chosen because of their habit to exclusively bottom feed and their tendency to bioaccumulate sediment-borne contaminants. Samples of tissue media comprised (1) fillets, skin-off, for channel catfish, largemouth bass, and common carp; (2) fillets, skin-on, for channel catfish and largemouth bass; (3) eviscerated whole fish for channel catfish; and (4) fish livers for largemouth bass and common carp. 


\section{Sampling Methods}

Stormwater samples were collected (Phase I) by automatic samplers that collect flow-weighted composite samples (Raines and others, 1997). Individual samples of equal volume were collected each time a specified volume of flow passed the flow-control structure. Hand-dipped composite samples were collected for volatile organic compound (VOC) analysis. Precipitation, in 0.25 -millimeter $(\mathrm{mm})$ increments, was measured by a tipping-bucket rain gage attached to the gage house. The water elevation (stage) in a culvert or drainage channel was measured by a pressure gage. Discharge was computed using the measured stage and a theoretical equation based on the type of flow-control structure.

Suspended sediment samples for chemical analysis were collected (Phase II) during storms with a minimum of $2.5 \mathrm{~mm}$ of precipitation and 72 hours between storms. Sampling targeted the rising limb and the peak of the storm hydrograph. Because total suspended sediment (TSS) concentrations were small, from less than 5 to 71 milligrams per liter $(\mathrm{mg} / \mathrm{L})$ in Phase I stormwater samples, suspended sediment from as much as 200 liters (L) of water was required to provide the mass of sediment necessary for direct chemical analysis. During the early part of a storm, a high-volume peristaltic pump was used to pump water from the estimated centroid of flow through Teflon-lined tubing into a $200-\mathrm{L}$ Teflon bag lining a plastic drum. Sand-size and larger particles (greater than $0.063 \mathrm{~mm}$ ) were trapped by a polyester mesh and removed before water entered the drum.

Silt- and clay-size particles were removed by filtration from the water in the 200-L drum. Pre-cleaned glass-fiber filters (293-mm diameter) with pore size of 0.7 -micrometer $(\mu \mathrm{m})$ were held in stainless steel filter holders and used to trap as much as 3 grams ( $\mathrm{g}$ ) of sediment for analysis of organic compounds. Filters loaded with sediment were analyzed for target constituents using the same extraction, cleanup, and quantification procedures that were used for Phase II bottom sediments. Major and trace element samples were collected on 140-mm diameter, $0.5-\mu \mathrm{m}$ pore size, Teflon filters held in acrylic filter holders. Loaded filters were placed in plastic bags with a small amount of distilled water to flush sediment off the filter. The sediment and distilled water then were transferred to plastic containers, and the sample was freeze-dried. A minimum of 300 milligrams (mg) of sediment was required for analysis of major and trace elements using the analytical methods of Lichte and others (1987) and Fishman (1993).

Lake-water sample collection (Phase I) began with vertical profiles of $\mathrm{pH}$, temperature, specific conductance, and dissolved oxygen. These field properties were measured at $0.6-\mathrm{m}$ intervals by lowering a sampling tube to the desired depth and pumping water to the surface where the field properties were measured using a Hydrolab. Because no thermocline or oxycline was indicated, one depth-integrated sample was collected at each site. Sample-processing (compositing, filtering, and treating samples) was done following USGS protocols (Ward and Harr, 1990).

Lake-bottom sediment samples were collected (Phase I and Phase II) from Mountain Creek Lake using box corers and gravity corers (Jones and others, 1997) following methods of the USGS National Water Quality Assessment (NAWQA) program (Van Metre and Callender, 1997; Van Metre, Callender, and Fuller, 1997). At sites where surficial samples were collected by box corer, a gravity core was collected first to determine the thickness and character of lacustrine sediments. A standard "surficial bottom sediment sample" was the top $3 \mathrm{~cm}$ of sediment from a box core. One or two deeper intervals, usually 3 to $9 \mathrm{~cm}$ and 9 to $15 \mathrm{~cm}$, also were sampled from box cores at eight sites in Cottonwood Bay during Phase II (fig. 2). Gravity cores were collected at three sites during Phase I (fig. 1) and at one site (M2.40) during Phase II (fig. 2) for chemical analysis of deeper, older sediments. The cores were subsampled by vertically extruding the sample using a piston that fits inside the core liner, pushing the sample upward in the liner, and slicing off selected intervals with a thin stainless steel plate.

Streambed sediment samples were collected (Phase I and Phase II) following the methods of Ward and Harr (1990). The surficial material from the streambed was collected and composited, then wet-sieved in the field using native water. Wet-sieving before analysis provides better comparability among samples because smaller grain size yields a greater specific surface area, and many trace contaminants adsorb to the surface of sediments. The silt and clay fraction less than $0.063 \mathrm{~mm}$ was retained for inorganics analyses. The fraction less than $2 \mathrm{~mm}$ was retained for organics analyses.

Fish samples were collected during Phase I using an electrofishing boat. Largemouth bass and common carp were placed in an onboard, aerated holding tank that contained water from the lake. Either four or five individual whole carp from each of three sites in the lake 
were composited at the laboratory before analysis. Bass fillet samples were collected as whole, skinless fillets (Crawford and Luoma, 1993). Fillets from five fish from each of three sites were composited at the laboratory for analysis. Phase I analysis of major and trace elements in fish was done on fish livers from both carp and bass. Liver tissue weighing 3 to $5 \mathrm{~g}$ was excised from each of five fish collected from each site, with a minimum of $10 \mathrm{~g}$ (wet weight) required for a composite sample of each species.

Individual fish were collected during Phase II using an electrofishing boat and gill nets. Phase II samples comprised channel catfish, largemouth bass, and common carp; sample types comprised fillets with skin off, fillets with skin on, and eviscerated whole fish. The target sample size of 10 fish of each species and tissue type was achieved, except for channel catfish with a sample size of nine whole-body, eviscerated fish. Size ranges for largemouth bass (304 to $352 \mathrm{~mm}$ ) and common carp (420 to $496 \mathrm{~mm}$ ) were within 25 percent of maximum size as planned. Three additional bass greater than $400 \mathrm{~mm}$ were submitted for analysis on the basis of a recommendation from the Texas Department of Health (Kirk Wiles, Texas Department of Health, oral commun., 1996). Difficulties in collecting channel catfish precluded meeting size requirements across all tissue sample types.

\section{Analytical Methods}

Methods of analysis of Phase I stormwater samples are documented in Raines and others (1997). Analyses of lake water samples were done using the procedures described in Fishman and Friedman (1989) and Fishman (1993). Major element concentrations were determined by colorimetric analysis, trace element concentrations were determined using inductively coupled plasma (ICP), and organic carbon concentrations were determined with a carbon analyzer. Pesticide concentrations were determined by gas chromatography/ mass spectrometry (GC/MS) and by high-pressure liquid chromatography. VOC analyses were done using GC/MS.

Lake-bottom sediment grain-size analyses were done at the USGS sediment laboratory in Iowa City, Iowa, using sieve and pipet methods (Carol Anderson, U.S. Geological Survey, written commun., 1993). Phase I lake-bottom sediment pesticide and polychlorinated biphenyl (PCB) analyses were done by gas chromatography/electron capture detection
(GC/ECD) (Wershaw and others, 1987). Phase I semivolatile organic compound (SVOC) analyses were done on organic-sediment extracts using GC/MS following the methods of Furlong and others (1996). Phase I major and trace element concentrations were determined on concentrated-acid digests (nitric-hydrofluoricperchloric acids) using ICP-atomic emission spectrometry (ICP-AES) (Lichte and others, 1987). Phase II polycyclic aromatic hydrocarbon (PAH) analyses were done following the extraction and cleanup procedures of Furlong and others (1996), with selected ion monitoring for PAHs by GC/MS (E.T. Furlong, U.S. Geological Survey, written commun., 1996). Pesticide and PCB analyses were done on organic-solvent extracts using the extraction procedures described by Foreman and others (1995) and the quantification procedures described by Wershaw and others (1987). PCBs and chlordane compounds were reported as Aroclors 1242, 1254 , and 1260, and as technical chlordane, respectively. Phase II analyses of major and trace elements included ICP-AES; chromium, lead, and zinc were determined by graphite-furnace atomic adsorption; mercury was determined by cold vapor; and selenium was determined by hydride generation (Lichte and others, 1987; Fishman, 1993). Suspended sediment samples (Phase II) were analyzed using the same methods as Phase II lake-bottom sediment samples.

Fish samples analyzed for pesticides and PCBs were first homogenized to form a single composite sample (homogenate). A10-g homogenate subsample was extracted with organic solvents and gel permeation chromatography (GPC) procedures to concentrate and remove lipids from the extract. Percent lipid was determined for each sample to allow for normalization of data as needed. Prepared extracts were analyzed by GC/ECD (Leiker, 1995), and concentrations of individual compounds were quantified at a minimum reporting level (MRL) of 5.0 micrograms per kilogram $(\mu \mathrm{g} / \mathrm{kg})$ wet weight (U.S. Geological Survey, 1994). PCBs and chlordane compounds were reported as Aroclors 1242, 1254, and 1260, and as technical chlordane, respectively.

Liver tissues and fillets subsampled for trace element analysis were prepared by oven-drying to a constant weight, dissolution of the sample by acid digestion and the addition of hydrogen peroxide, and filtration of remaining insoluble materials (U.S. Geological Survey, 1993). Concentrations of trace 


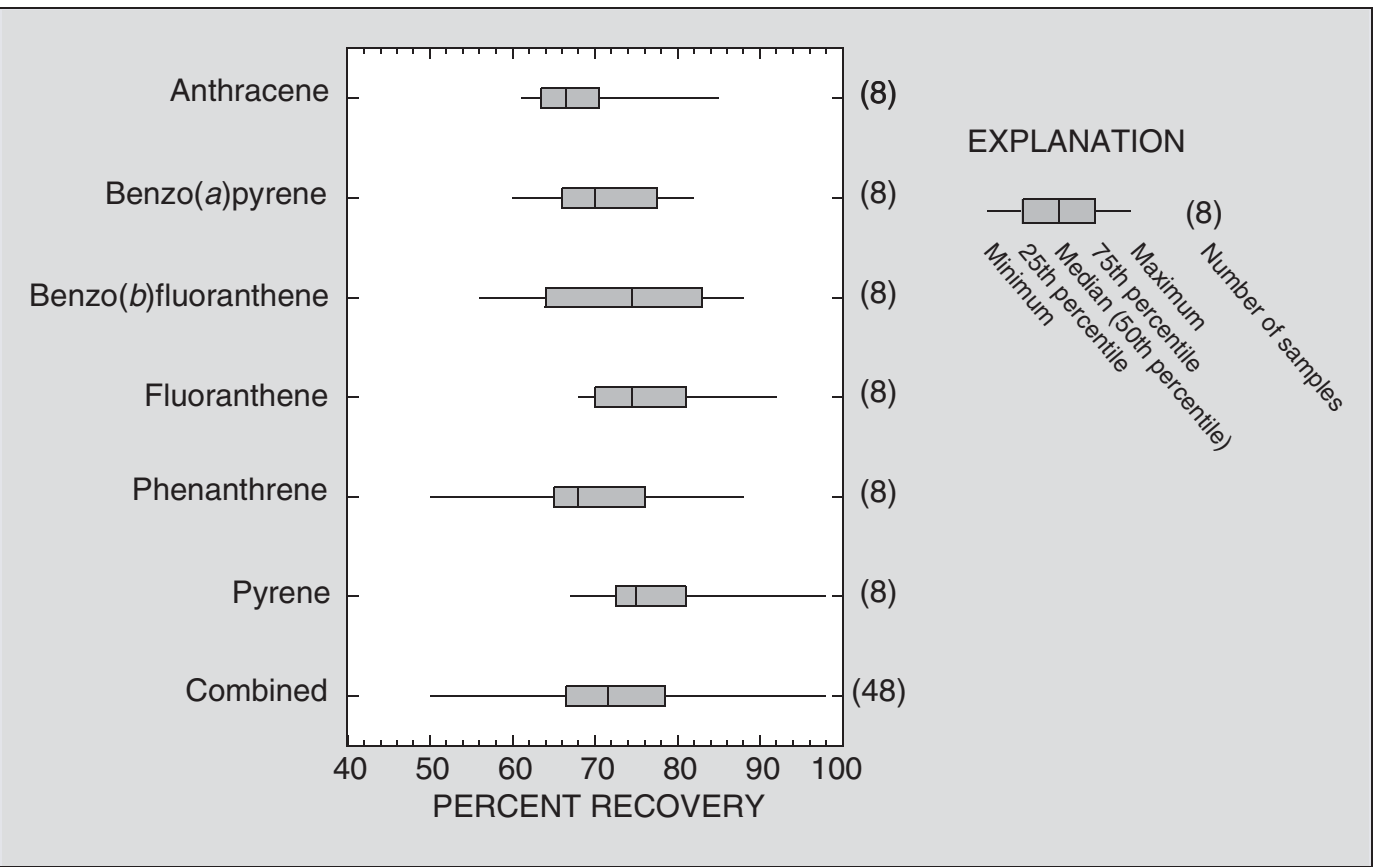

Figure 3. Percent recovery of laboratory spiked quality-control samples for polycyclic aromatic hydrocarbons in bottom sediment collected at Mountain Creek Lake, Dallas, Texas.

elements were determined in the acid-digested biological material (Fishman and Friedman, 1989; Faires, 1993). Whole-body, eviscerated samples were homogenized using a stainless steel grinder; a 20-g subsample was retained for trace element analysis following the procedures described above.

VOCs were analyzed using a method similar to the method recommended by the U.S. Environmental Protection Agency (USEPA) for analysis of VOCs in fish tissue (Easley and others, 1981). Ten milliliters of organic-free water and a spiked solution were added to each VOC subsample in a 1.9-cm-diameter glass test tube. The sample was then placed in an ice bath and subjected to a sonic disrupter for 2 minutes, then loaded into a Tekmar ${ }^{\mathrm{TM}} 2016$ autosampler. The sampler is outfitted with a modified purge needle. The sample was heated to 70 degrees Celsius $\left({ }^{\circ} \mathrm{C}\right)$ for 2 minutes before the purge cycle. The sample was desorbed into the gas chromatograph (GC), which is temperature programmed from -20 to $160^{\circ} \mathrm{C}$, and analyzed by electron impact mass spectrometry in the full-scan mode.

SVOCs in fish were analyzed using the extraction and cleanup procedures described in Leiker (1995) and the quantification procedures developed for sediment samples in Furlong and others (1996).

\section{Quality Control}

Quality-control sample types and qualityassurance elements of the Mountain Creek Lake study are described in a written study plan provided to the Navy and regulatory agencies (USEPA and Texas Natural Resource Conservation Commission [TNRCC]) before sampling. Selected quality-control data for samples collected at Mountain Creek Lake are listed in Jones and others (1997). Quality-control data are used to estimate the bias and variability in environmental data. Bias is the systematic error inherent in a method or caused by some artifact of the measurement system. Variability is the degree of variation in independent measurements as the result of repeated application of the measurement process. Quality-assurance elements are specifications of methods of sample collection, procedures for sample processing, methods of laboratory analysis, and collection of field quality-control samples.

Spiked sediment samples were used to evaluate bias caused by analytical methods. The median percent recovery for 48 spikes (eight each for anthracene, benzo $(a)$ pyrene, $\operatorname{benzo}(b)$ fluoranthene, fluoranthene, phenanthrene, and pyrene) was 71.5 percent during Phase II (fig. 3). Recoveries ranged from 50 to 98 percent, which met laboratory-established control limits. 


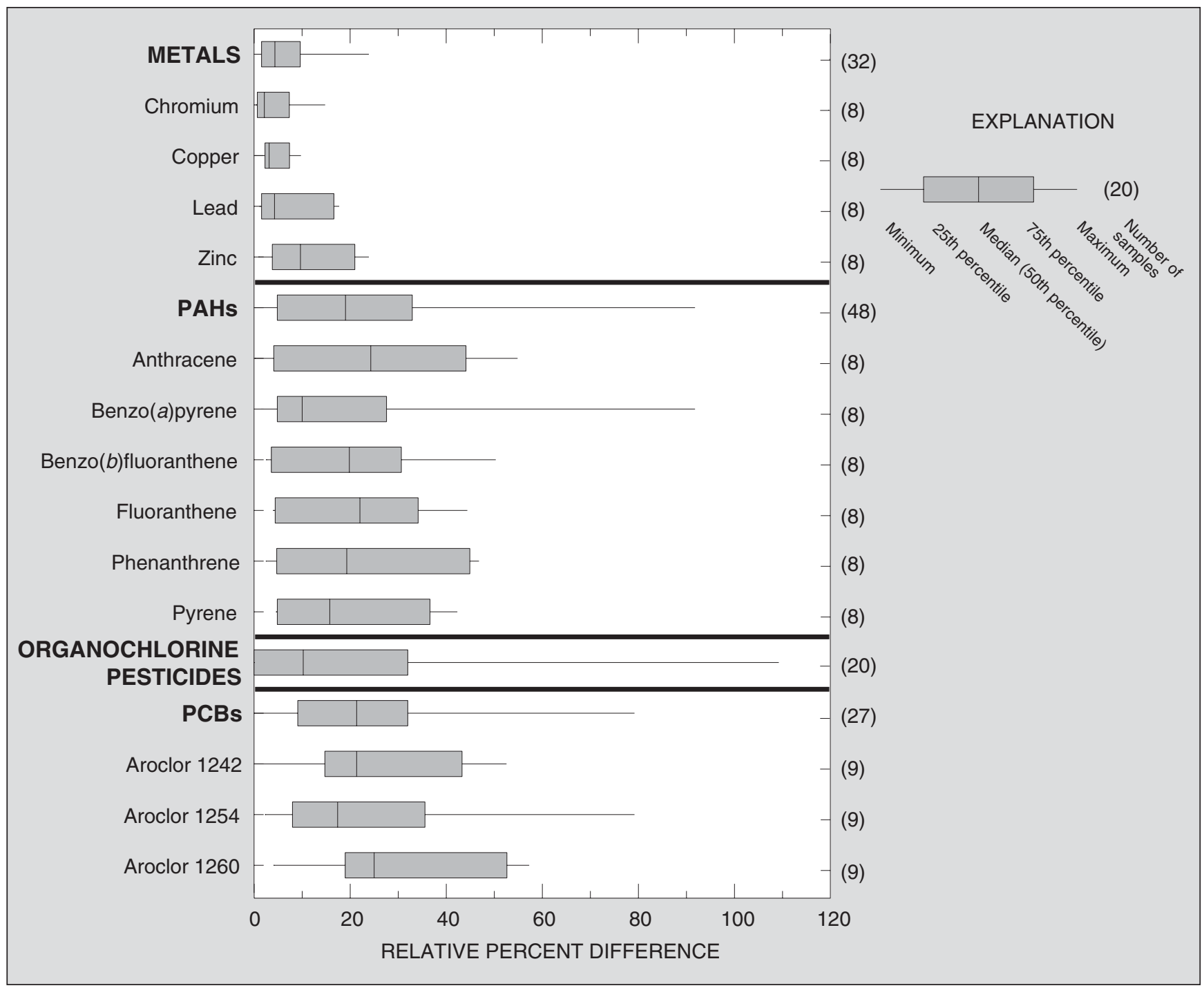

Figure 4. Percent differences between environmental and replicate samples in lake bottom sediment collected at Mountain Creek Lake, Dallas, Texas.

Replicate sediment samples were collected by splitting the environmental samples in the field. Replicate samples allow measurement of the variability in the analytical values produced by processing and transport of the samples and by the analytical method. Relative percent difference (RPD) between the environmental and replicate samples, which is defined as the difference divided by the average multiplied by 100 , is a measure of this variability.

Metals show the least variability as measured by the RPD (fig. 4). The median RPD for 32 replicate analyses of metals (eight samples each for chromium, copper, lead, and zinc) in bottom sediments collected during Phase I and Phase II was 4.3 percent. The median
RPD for PAHs in 48 replicate samples (eight samples each for anthracene, benzo $(a)$ pyrene, benzo $(b)$ fluoranthene, fluoranthene, phenanthrene, and pyrene) in bottom sediments collected during Phase II was 19 percent. The median RPD for 20 organochlorine pesticide samples in bottom sediment collected during both phases was 11 percent (four samples each for chlordane, DDD, DDE, DDT, and dieldrin). Several of the pesticide environmental and replicate samples were below method detection limits, which resulted in an RPD of zero. The median RPD for PCBs in 27 replicate samples (nine samples each for Aroclors 1242, 1254, and 1260) collected in bottom sediment during both phases was 21 percent. 


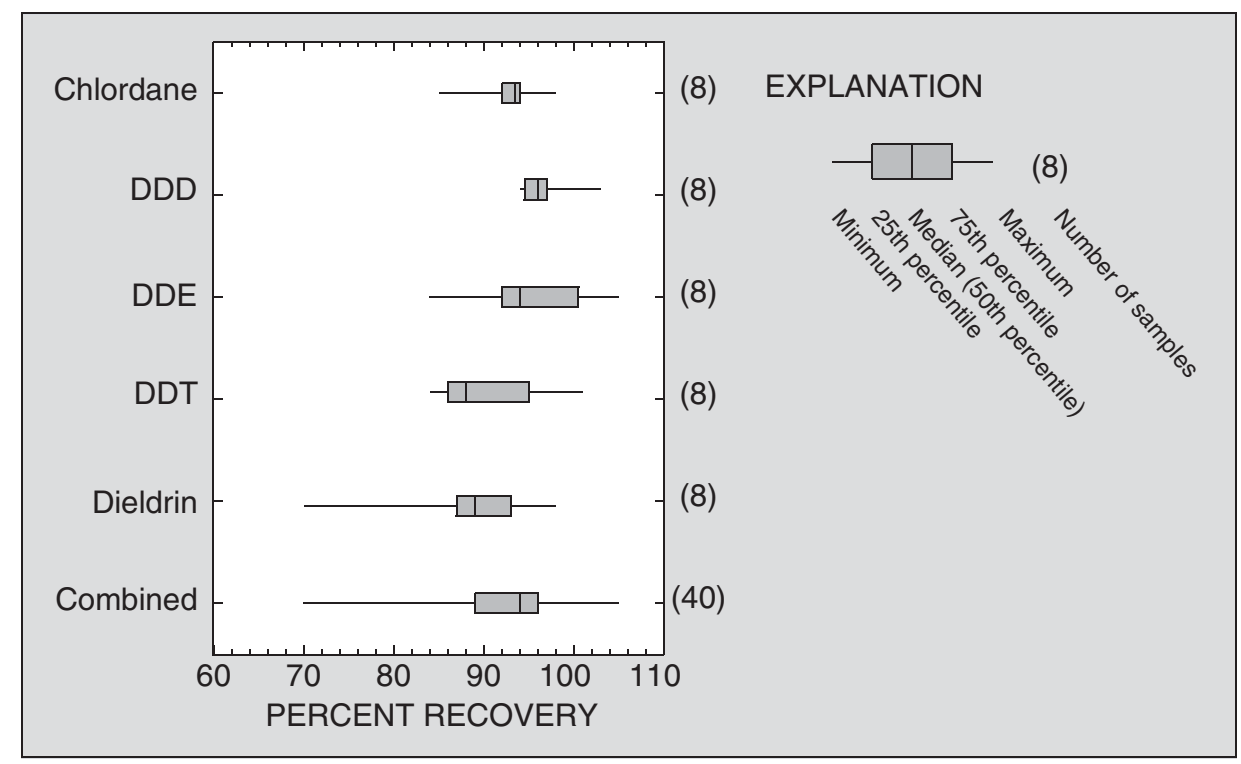

Figure 5. Percent recovery of laboratory spiked quality-control samples for organochlorine pesticides in fish tissue collected at Mountain Creek Lake, Dallas, Texas.

Stormwater and lake water samples collected during Phase I were monitored for field contamination from VOCs and trace elements by collecting field blanks and by including trip blanks (VOCs only) in coolers with environmental samples. Blank and spike solutions were analyzed in the laboratory along with each batch of water samples analyzed. The qualitycontrol data were within acceptable ranges, except for stormwater samples collected by automatic sampler at one site in which blank contamination for VOCs occurred (Raines and others, 1997). It was determined that contamination of the pump tubing had occurred during the previous storm. To avoid additional sample contamination, pump tubing was replaced after each use.

Laboratory blanks and spikes also were run for fish-tissue samples (Jones and others, 1997). Median percent recovery for 40 spikes for organochlorine pesticides (eight each for chlordane, DDD, DDE, DDT, and dieldrin) was 94 percent during Phase II (fig. 5). The spike recovery range of 70 to 105 percent met laboratory-established control limits.

\section{POTENTIAL SOURCES OF CONTAMI- NATION FROM NAVY FACILITIES TO MOUNTAIN CREEK LAKE}

Contaminants could reach Mountain Creek Lake from several sources and by several pathways. Pathways include wash-off of contaminants from surrounding areas by stormwater, direct (point-source) discharges of wastewater, and inflow of ground water to the lake. Wash-off, direct discharges, and ground-water inflows could come from several industrial facilities in the Mountain Creek Lake watershed including the Navy facilities and commercial or urbanized areas of the Cottonwood Creek watershed. Some contaminants, lead and mercury for example, also can reach lakes from local and regional atmospheric sources.

This section briefly summarizes the current (1998) understanding of historical releases and presentday occurrence of contaminants on Navy facilities. In some cases, more detailed information of the on-site occurrence of some contaminants is presented in following sections, which discuss potential sources of specific elements and compounds. The information in this section is from the Navy and its contractors, primarily EnSafe. Selected information on recent inputs of containments from the Cottonwood Creek watershed obtained during this investigation is presented with other chemical results.

\section{NWIRP Sources}

During 1941-74, the NWIRP facility discharged stormwater runoff, treated sanitary sewage, and industrial process wastewater into the west and east lagoons (fig. 1). Waste disposal into the west lagoon, which 
Table 3. Waste disposed of in the west lagoon, Naval Weapons Industrial Reserve Plant

[From Ensafe/Allen \& Hoshall, 1996a]

\begin{tabular}{|c|c|c|c|c|}
\hline Period & Waste type & $\begin{array}{c}\text { Total } \\
\text { discharge } \\
\text { (cubic meters) }\end{array}$ & $\begin{array}{c}\text { Average daily } \\
\text { discharge } \\
\text { (cubic meters } \\
\text { per day) }\end{array}$ & Sources \\
\hline $1941-74$ & $\begin{array}{l}\text { Metal plating solutions containing magnesium } \\
(\mathrm{Mg}) \text {, nickel }(\mathrm{Ni}) \text {, titanium }(\mathrm{Ti}) \text {, copper }(\mathrm{Cu}) \text {, } \\
\text { cadmium }(\mathrm{Cd}), \text { chromium }(\mathrm{Cr}) \text {, and zinc }(\mathrm{Zn})\end{array}$ & 42 & 0.003 & Plating shops \\
\hline $1941-74$ & Metal plating rinse water & $2,800,000$ & 220 & Plating shops \\
\hline $1941-74$ & $\begin{array}{l}\text { Neutralized acid solutions (sulfuric, nitric, } \\
\text { chromic, phosphoric, hydrofluoric) }\end{array}$ & 170 & .014 & Plating shops \\
\hline $1941-74$ & Alkaline cleaning solutions & 38 & .003 & Plating shops \\
\hline $1941-74$ & $\begin{array}{l}\text { Waste petroleum, oil, and lubricants and plant- } \\
\text { wide stormwater runoff }\end{array}$ & Undetermined & Undetermined & $\begin{array}{l}\text { Plant-wide storm runoff and } \\
\text { shop floor washdown water }\end{array}$ \\
\hline $1941-74$ & $\begin{array}{l}\text { Solvents (acetone, methyl ethyl ketone, } \\
\text { isopropanol) }\end{array}$ & 25 & .002 & Bond shop \\
\hline $1941-74$ & 4 Treated effluent from the sewage treatment plant & $11,000,000$ & 910 & Plant-wide \\
\hline $1941-74$ & Boiler and cooling tower blowdown & 98,000 & 7.9 & Plant-wide \\
\hline $1967-74$ & Phenolic stripper rinse water & 11,000 & .9 & Aluminum parts stripper shop \\
\hline $1974-84$ & 4 Herbicide rinse water & 5 & .0003 & Herbicide formulation \\
\hline
\end{tabular}

flows into Cottonwood Bay, was estimated as 1,300

$\mathrm{m}^{3} / \mathrm{d}$ (cubic meters per day) including an undetermined amount of waste petroleum, oil, and lubricants mixed with storm runoff. Of the $1,300 \mathrm{~m}^{3} / \mathrm{d}$, about $1,150 \mathrm{~m}^{3} / \mathrm{d}$ is attributed to facility processes (table 3 ) (EnSafe/Allen \& Hoshall, 1996a). Beginning in 1974, sewage generated on the facility was discharged to the City of Dallas sanitary sewer system, and much of the facility's process wastewater was routed to the industrial waste treatment plant (IWTP) for treatment before discharge to the sanitary sewer. A control system was built in 1974 to reduce the amount of flow entering Cottonwood Bay from the west lagoon. The system diverts 110 to $190 \mathrm{~m}^{3} / \mathrm{d}$ to the IWTP for treatment before discharge to the sanitary sewer system. During 1974-84 the west lagoon received about 570 to $760 \mathrm{~m}^{3} / \mathrm{d}$ of flow from unspecified sources. In March 1992, miscellaneous and previously unidentified wastewater lines discharging into the lagoon were disconnected. Dry-weather flow to west lagoon now ranges from 110 to $190 \mathrm{~m}^{3} / \mathrm{d}$ and still contains some process wastewater, most of which is captured by the diversion system to the IWTP (EnSafe/ Allen \& Hoshall, 1996a).

During 1941-74 the east lagoon received an unknown quantity of treated sanitary sewage. Since
1974 the lagoon has received primarily stormwater runoff. This runoff contained about 0.4 cubic meter per year $\left(\mathrm{m}^{3} / \mathrm{yr}\right)$ of spilled fuel and oil from aircraft fueling and maintenance areas in the east lagoon drainage area. In 1971 an oil-spill recovery system was installed at the southern end of the lagoon to reduce the fuel and oil discharge into Cottonwood Bay.

In addition to the waste disposal in the lagoons, the large manufacturing buildings ( 1 and 6, fig. 6 ) house degreaser vats which historically used trichloroethene (TCE) as a degreasing solvent. A large TCE groundwater plume is present at the site. An off-site source west of the NWIRP might also contribute to the plume at the site. A recently developed ground-water-flow model indicates that about $70 \mathrm{~m}^{3} / \mathrm{d}$ of ground water is discharging to the east and west lagoons (Barker and Braun, 2000).

\section{NAS Sources}

Six identified solid-waste management units (SWMUs) (Groups 9, 12, and 14 and buildings 43, 51, and 178 in fig. 6) are located in the drainage area of the NAS-1 stormwater site (fig. 1). Documented petroleum, oil, and lubricant (POL) spills have occurred. 


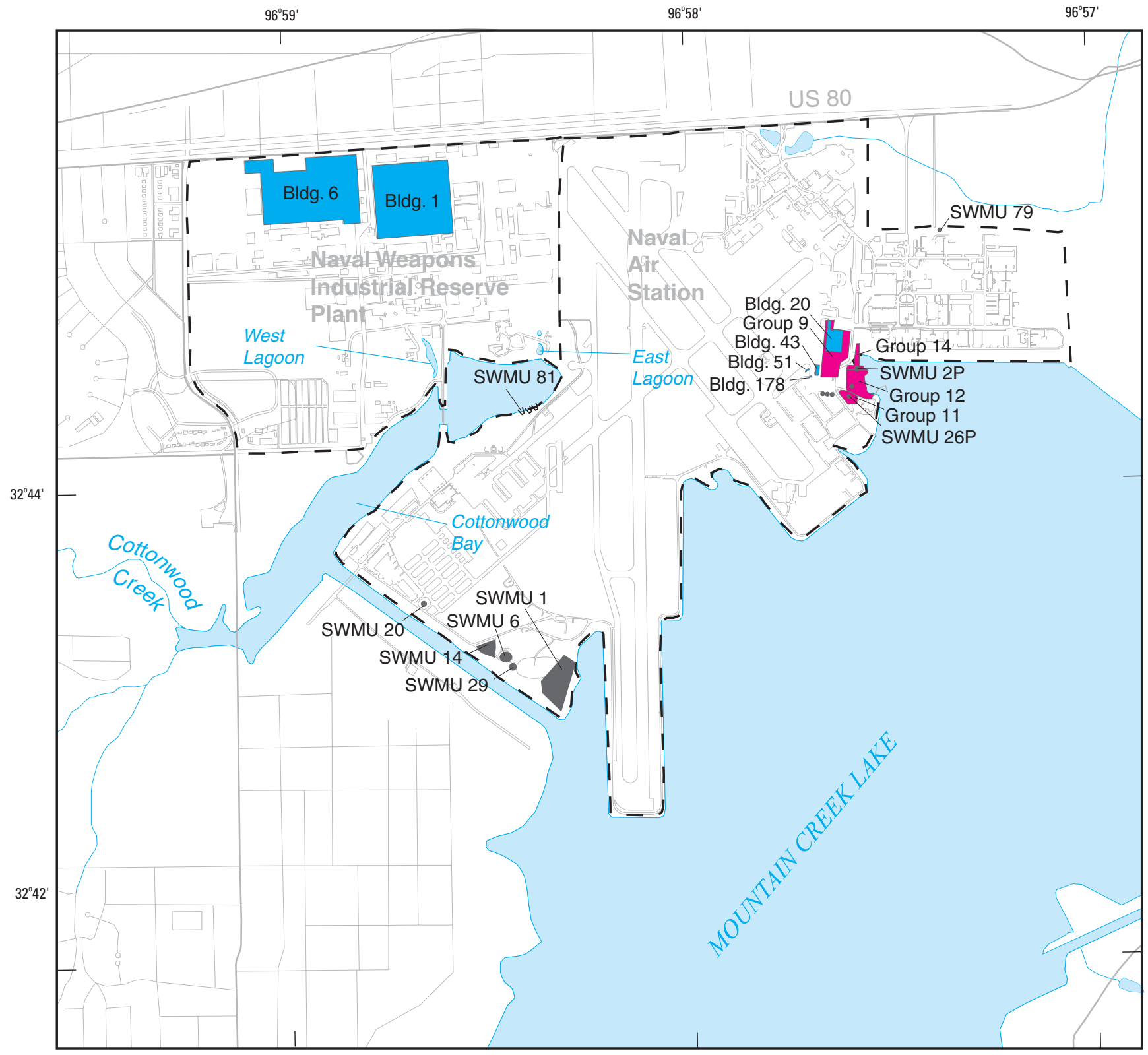

Base from EnSafe/Allen \& Hoshall written commun., 1996 Modified State Plane

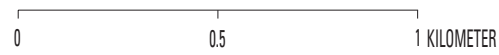

\section{EXPLANATION}

\section{Building of interest \\ Group of interest \\ SWMU of interest \\ - - - Boundary of Naval Weapons Industrial Reserve Plant and Naval Air Station}

Figure 6. Locations of selected buildings, groups, and solid-waste management units (SWMUs) on the Naval Air Station and Naval Weapons Industrial Reserve Plant, Dallas, Texas. 
A fuel farm is located just north of building 20. Group 12 currently (1998) houses the Public Works storage area, but formerly contained a sewage treatment plant and possibly a sludge-drying bed. No VOC contamination is suspected from this area. Group 14 is located nearest the NAS-1 stormwater site. A 38-cubic meter $\left(\mathrm{m}^{3}\right)$ steel storage tank located in this group is suspected of being the source of an on-site TCE ground-water plume mapped by EnSafe. Additional sources in this area include a former aircraft wash area (where solvents were used) and a drum storage area (EnSafe/Allen \& Hoshall, 1996b).

Stormwater site NAS-2 (fig. 1) is located on the part of NAS that houses the administrative, recreational, and residential areas of the base, but the drainage area includes the main fuel farm (SWMU 79) for the facility. NAS-2 receives flow from stormwater and sanitary sewers in addition to surface runoff. Fuel spills historically have been routed to the fuel farm storm sewers and tanks (EnSafe/Allen \& Hoshall, 1997b).

Stormwater site NAS-3 (fig. 1) is located in the northeastern corner of NAS in the oldest developed part of the facility. The area currently (1998) is used by the Texas Air National Guard (TANG), Marine Air Group 41, Navy vehicle maintenance, and fire department. The TANG storm sewers discharge to an unlined ditch near NAS-3. These storm sewers collect spills and wash water from the TANG maintenance hanger, aircraft maintenance hanger, transport hanger, and aircraft wash rack. Chemicals released to the storm sewers include solvents, cleaning compounds, detergents, degreasers, hydraulic oils, motor oils, and kerosene. The Navy transformer station is directly north of NAS-3.

\section{CHEMICAL QUALITY OF WATER, SEDIMENT, AND FISH IN MOUNTAIN CREEK LAKE}

The occurrence, trends, and sources of chemical constituents presented and discussed in this section are organized by chemical groups, which comprise metals, VOCs, PAHs, organochlorine pesticides, and PCBs. Within each chemical group, discussions are organized by environmental phase, as applicable, including stormwater, lake water, sediment, and fish.

Discussions of spatial occurrence require a common locational reference for the lake and surrounding areas. Three sets of locations typically are referred to: Phase I sampling sites (fig. 1), Phase II sampling sites/areas (fig. 2), and place names associated with the lake (fig. 7). Some of the place names in figure 7 are official; others are used only in this report and have been established to facilitate discussion.

\section{Reference Concentrations}

Comparisons of concentrations in any given sample to reference concentrations can indicate the magnitude of a land-use-related effect of interest. Two types of reference concentrations were used: (1) main lake and (2) urban. Main lake reference concentrations are typical of the main body of Mountain Creek Lake remote from the Navy facilities at sites not directly affected by runoff of contaminants from either the Navy facilities or the nearby urban areas of Dallas or Grand Prairie. Urban reference concentrations are of interest because much of the activity at the Navy facilities is similar to urban areas in general, for example the large parking areas and associated automobile traffic. Three sites were chosen on the basis of watershed land-use characteristics to provide urban reference concentrations. Two sites sampled in this study are on the north and south forks of Cottonwood Creek. Cottonwood Creek drains parts of Grand Prairie and does not receive drainage from Navy facilities. The third site is White Rock Lake in northeastern Dallas, a reservoir with an urbanized watershed in a geologic setting similar to that of Mountain Creek Lake. Age-dated sediment cores were collected from White Rock Lake in 1994 and 1996 and interpreted to describe trends in water quality using methods similar to those used at Mountain Creek Lake (Van Metre and Callender, 1997; Van Metre and others, 2000).

A reproducible, statistically based method for describing reference concentrations of possible contaminants can reduce the potential for bias in interpretation of environmental data. The largest datasets generated by this study are for sediments and fish tissues. Because fish are able to move around the lake, their exposure history to site specific inputs is unknown; therefore, no attempt was made to describe reference concentrations of contaminants in fish. The same is also true of water. Sediments, however, generally remain in place after deposition on the bottom of a lake, except in near-shore areas where wave action can cause resuspension. The stability of lake sediment deposits over time is demonstrated by age-dated sediment cores from lakes (Van Metre and others, 1998). Therefore, only main lake reference concentrations were computed and used in this report for bottom sediment data. 


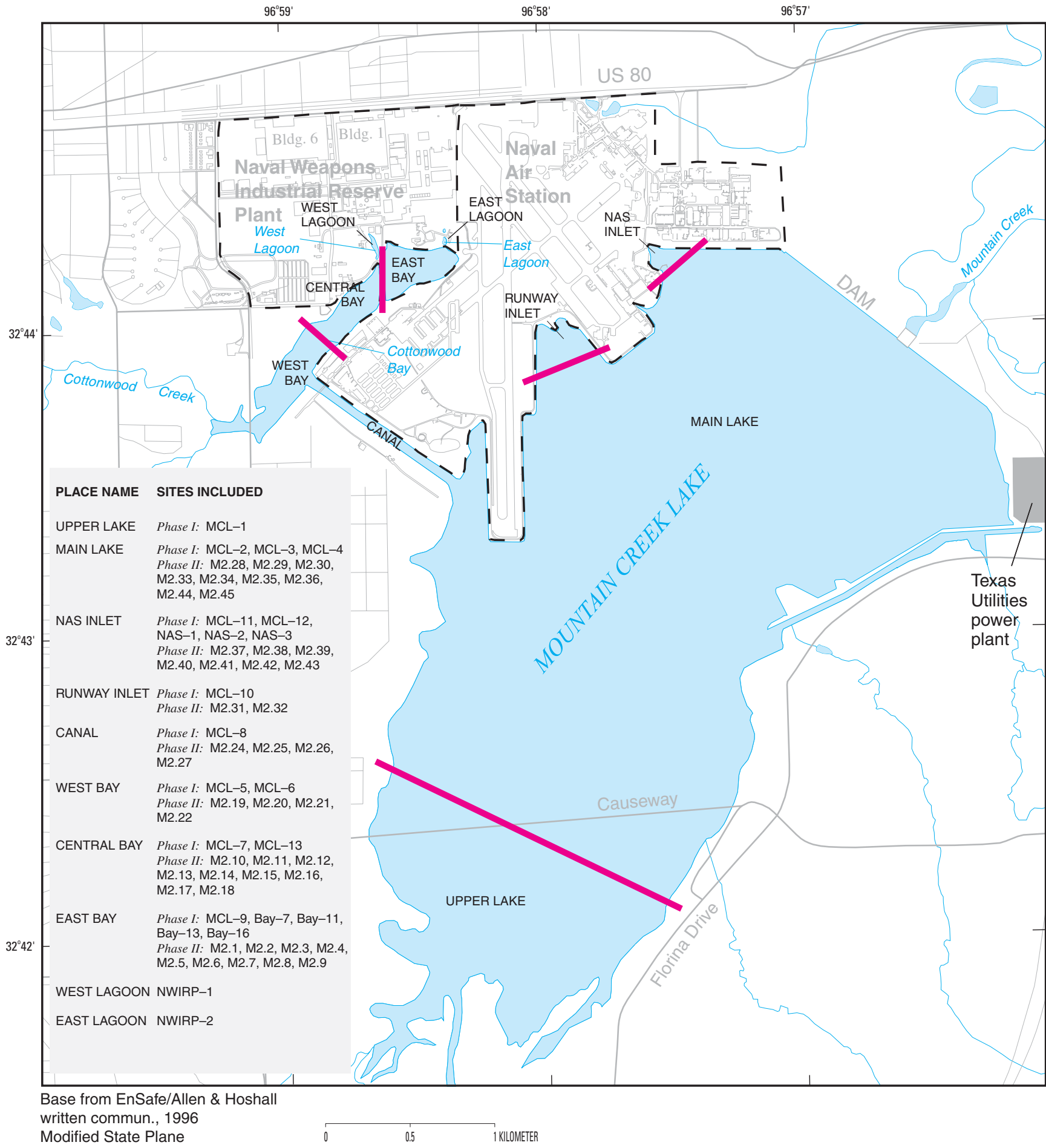

\section{EXPLANATION}

- - - Boundary of Naval Weapons Industrial Reserve Plant and Naval Air Station

Boundary between parts of Mountain Creek Lake

Figure 7. Place names of parts of Mountain Creek Lake used in this report. 
Table 4. Sites included in cluster analysis

[NAS, Naval Air Station]

\begin{tabular}{cll}
\hline Cluster & \multicolumn{1}{c}{ Location } & \multicolumn{1}{c}{ Sites included in cluster } \\
\hline 1 & Cottonwood Bay & Phase I: MCL-7, MCL-13, Bay-7 \\
& & Phase II: M2.1, M2.2, M2.3, M2.4, M2.5, M2.6, M2.7, M2.8, M2.9, M2.10, M2.11, \\
& & M2.12, M2.13, M2.14, M2.15, M2.16, M2.17, M2.18, M2.20, M2.21, M2.37, \\
& & M2.39 \\
2 & Canal/runway & Phase I: MCL-5, MCL-6, MCL-8, MCL-10, MCL-11 \\
& & Phase II: M2.19, M2.22, M2.24, M2.25, M2.26, M2.27, M2.28, M2.29, M2.30, \\
& & M2.33, M2.34, M2.35, M2.36, M2.41, M2.45 \\
3 & Runway inlet/NAS & Phase I: MCL-12 \\
& inlet & Phase II: M2.31, M2.32, M2.38 \\
4 & NAS inlet, outlier & Phase II: M2.42 \\
5 & Main-lake reference & Phase I: MCL-1, MCL-2, MCL-3, MCL-4 \\
& & Phase II: M2.43, M2.44 \\
6 & Cottonwood Bay, & Phase I: MCL-9 \\
& outlier &
\end{tabular}

Cluster analysis was used to group data on the basis of similar characteristics. Clustering forms groups of cases (sampling sites) on the basis of a distance measure between each case. In this application, the distance measure is based on relative concentrations of indicator contaminants. As nearby cases are grouped to form clusters, the distance to each new case is based on the centroid of cases in the group. The resulting number of clusters formed is controlled by the analyst. After cases are grouped, each cluster can be evaluated by the analyst to determine what part of the overall dataset the cluster represents. For example, one cluster could include only sampling sites from the upper part of the lake, whereas another could include only sites in Cottonwood Bay.

Although the clustering procedure is statistically based and reproducible, several judgment decisions were made that can affect the outcome. The first of these is the choice of what sites and what variables to include. All of the Phase I (except Bay-16) and Phase II surficial (0 to $3 \mathrm{~cm}$ ) lake-bottom sediment sampling sites (one sample per site) were included. Three chemical concentration variables were chosen as indicator contaminants: chromium, total PAHs (T-PAH), and PCBs. These three were chosen because each varied greatly in Mountain Creek Lake sediment, each represents a different group of potential contaminants with different sources and environmental behaviors, and each has sources on Navy facilities (EnSafe/Allen \& Hoshall, 1996a, b) and from other industrial and urban activities (Hites and others, 1981; Hem, 1985). Before clustering, concentrations were converted to logarithms and normalized by dividing each $(\log )$ concentration by the largest $(\log )$ concentration. The log transformations were done because the clustering is based on distance (measured in concentration difference) between cases. Chemical concentrations in the environment usually are log-normally distributed, so a log transformation moves large concentrations relatively closer to each other and spreads small and medium concentrations relatively farther apart. Normalization of each constituent to its largest concentration was done because the relative magnitudes of the concentrations are quite different. Thus normalization evens the weighting (or influence on the outcome) of chromium concentrations ( 21 to $360 \mu \mathrm{g} / \mathrm{g}$ [micrograms per gram]) and T-PAH concentrations (97 to $225,000 \mu \mathrm{g} / \mathrm{kg}$ ).

Six clusters were formed (fig. 8; table 4). Clusters 4 and 6 have only one site each, M2.42 and MCL-9, respectively (table 4 ). Site M2.42 has unusually small chromium and large PCB concentrations, making it an outlier relative to the other sites. Site MCL-9 has unusually large chromium and small PCB concentrations, making it an outlier as well. The remaining sites were grouped into four clusters. Twenty-three of the 


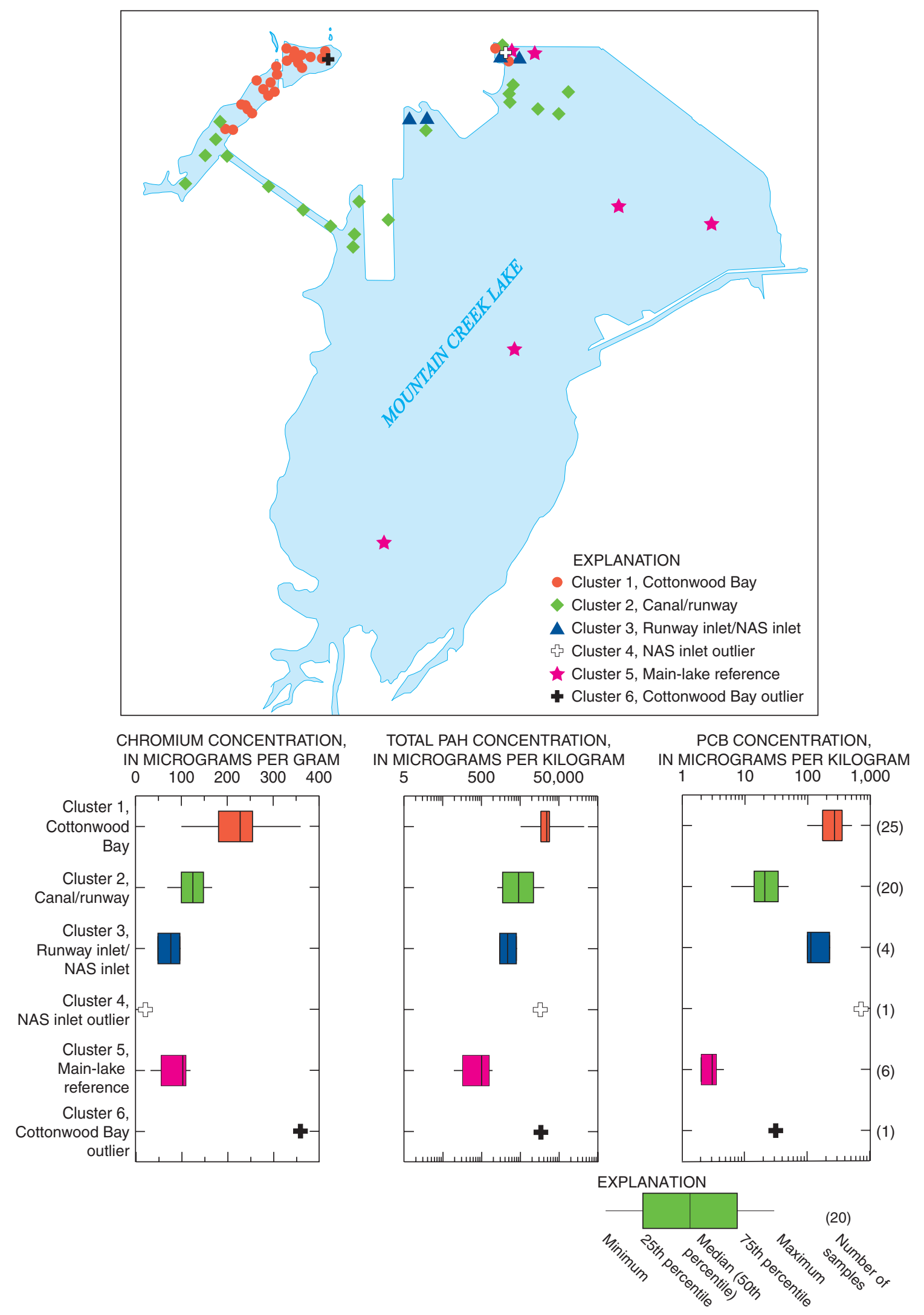

Figure 8. Locations of sites and range in selected constituents in bottom sediments for clusters. 
25 sites in cluster 1 are located in Cottonwood Bay. The other two sites, M2.37 and M2.39, are located in the NAS inlet. Of the four multisite clusters, cluster 1 has the largest concentrations of all three indicator variables (chromium, T-PAHs, and PCBs) that the clusters were based on. Cluster 2 has 20 sites. These sites are located in the west end of Cottonwood Bay, in the canal connecting to the main lake, along the west side of the runway, in the main lake, in the runway inlet, and in the NAS inlet. Concentrations of all three indicator variables are intermediate for this cluster. Cluster 3 has four sites, two in the runway inlet and two in the NAS inlet. These sites have relatively small chromium and T-PAH concentrations and relatively large PCB concentrations. Cluster 5 has six sites, one in the NAS inlet and the other five in the main and upper parts of the lake. With the exception of the anomalously small chromium concentration at site M2.42 (cluster 4), cluster 5 has the smallest concentrations of all three variables. It was thus designated as "main-lake reference."

\section{Dating Sediment Cores}

Historical trends in many persistent, hydrophobic contaminants can be identified by analyzing cores of bottom sediment from lakes and reservoirs (for example, Eisenreich and others, 1989; Callender and Van Metre, 1994; Van Metre and Callender, 1996, 1997). During storms, sediment is washed off the land surface and deposited in the lake. Over time, sediment accumulates in a thick layer on the bottom. More than $2 \mathrm{~m}$ of sediment has been deposited in the deepest part of Mountain Creek Lake since it was built in 1929. Coring through the sediment and analyzing discrete slices from the cores can allow a partial reconstruction of historical inputs of contaminants.

Gravity cores of deeper, older sediment were collected from two sites in Mountain Creek Lake (MCL-4 and M2.40) and two sites in Cottonwood Bay (MCL-7 and Bay-13) (figs. 1, 2). Cores were described visually on-site for color, texture, odor, and identification of the pre-reservoir land surface. The lacustrine (lake-deposited) sediments were characterized by uniform, fine-textured, olive-gray (5Y 4/1 on the Munsell rock color chart; Geological Society of America, 1991) and olive-black (5Y 2/1) clay-size material that oxidized to a dark yellowish brown (10YR 4/2) on exposure to air. Several black (N2 and N1) layers that had a strong hydrocarbon odor were noted in numerous reconnaissance cores and in cores from MCL-7 and
Bay-13 in Cottonwood Bay. Lacustrine sediment was more than 99 percent silt and clay (less than $0.062 \mathrm{~mm}$ ) with a median of 86 percent clay-size (less than 0.004 $\mathrm{mm}$ ) particles. Organic carbon concentrations, in weight percent, ranged from 1.1 to 3.4 (median 2.0, interquartile range 0.4 ) in gravity cores from sites MCL -4 and M2.40 in the main lake and were as large as 6.6 in samples from Cottonwood Bay.

Four approaches were used to assign deposition dates to individual sample intervals in gravity cores: (1) core lithology, specifically the visual and chemical identification of the pre-reservoir land surface in the core; (2) cesium-137 ( ${ }^{137} \mathrm{Cs}$ ) concentrations; (3) concentrations of DDT and dieldrin in relation to their historical uses; and (4) down-core sediment chemistry in relation to the discharge history of the west lagoon on NWIRP.

Lacustrine sediment begins to accumulate soon after a reservoir is impounded. The pre-reservoir land surface is easily identified in reservoir cores by the change in grain size and chemistry of sediments and by the presence of vegetative root hairs and other woody debris. Lacustrine sediment in Mountain Creek Lake immediately above the pre-reservoir material in a core, therefore, was assigned the date of reservoir impoundment, 1929. Because sediment continues to accumulate over time, the top of a core is assigned the sampling date.

Dating information was obtained at two coring locations by analyzing ${ }^{137} \mathrm{Cs}$. A by-product of nuclear weapons testing, ${ }^{137} \mathrm{Cs}$ has a half-life of 30.8 years. Appreciable concentrations of ${ }^{137} \mathrm{Cs}$ in the atmosphere first occurred in about 1952 with the advent of largescale weapons testing; atmospheric concentrations had a minor peak in 1958 and a major peak during 1963-64. Because ${ }^{137} \mathrm{Cs}$ sorbs strongly to fine-grained sediment, it is useful for dating sediment exposed to atmospheric fallout (Durrance, 1986).

${ }^{137} \mathrm{Cs}$ was detected in the deepest lacustrine sample (44- to 48-cm interval) and in the first sample of pre-reservoir material ( 48 to $52 \mathrm{~cm}$ ) from the M2.40 core and peaked in the 40- to 44-cm interval (fig. 9), indicating that the assumption of continuous sedimentation since impoundment in 1929 was not valid at this site. Sediment deposited there from 1929 until the early 1950s apparently was eroded, possibly because this site is relatively shallow and near shore and because lake levels have fluctuated historically. The ${ }^{137} \mathrm{Cs}$ peak and the shape of the ${ }^{137} \mathrm{Cs}$ profile in the upper part of the 


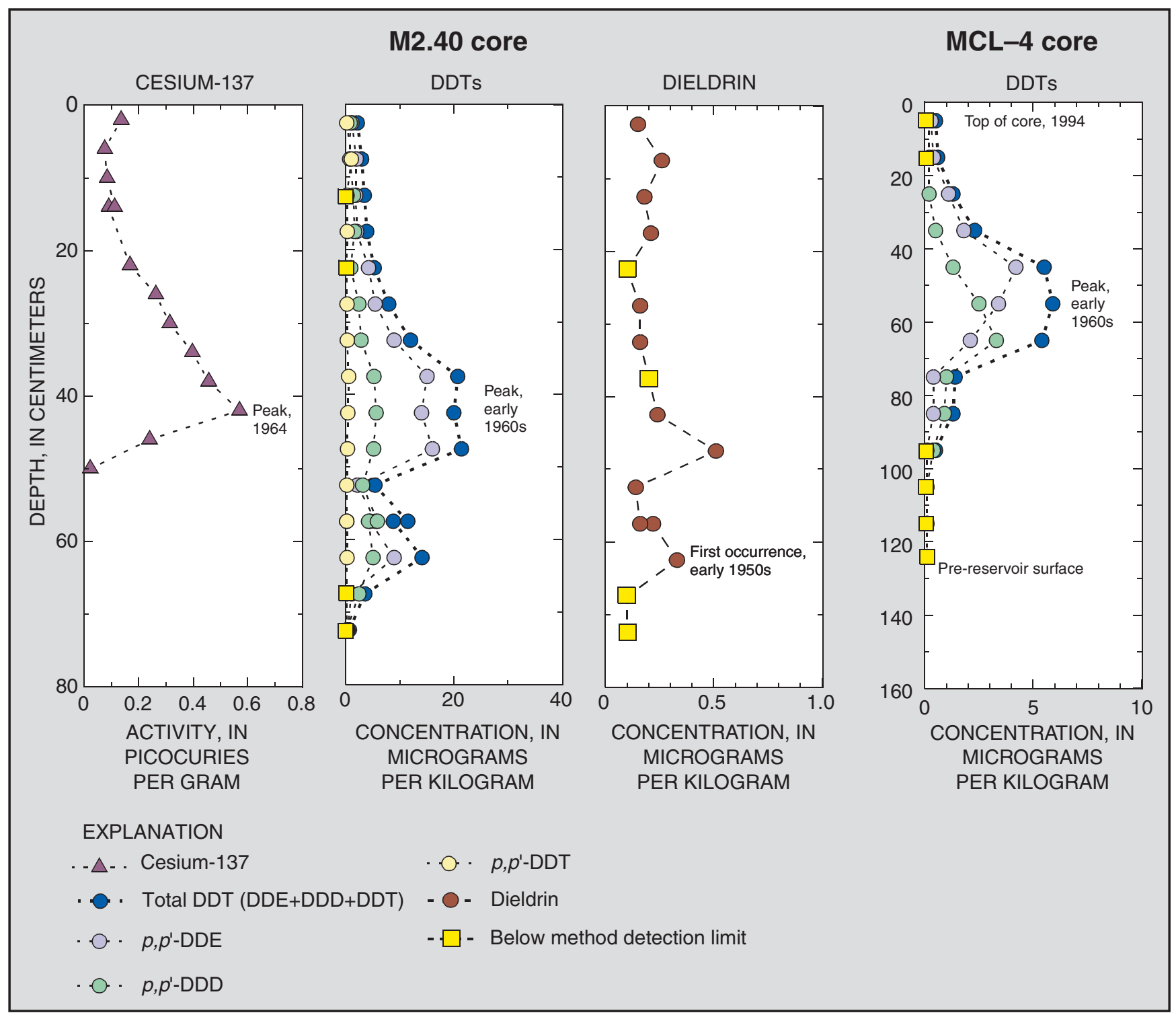

Figure 9. Cesium-137 and organochlorine pesticide concentrations in M2.40 and MCL-4 cores.

core indicate that continuous sedimentation has occurred since the 1950s.

The ${ }^{137} \mathrm{Cs}$ dating interpretation in the M2.40 core is supported by the total DDT $\left(p, p^{\prime}-\mathrm{DDE}+p, p^{\prime}-\mathrm{DDD}+\right.$ $p, p^{\prime}$-DDT) profile in a second core from the same site (fig. 9). Use of DDT peaked in the United States in the early 1960s (Rapaport and others, 1985). Total DDT profiles in reservoir sediment cores reflect this use history with peaks in total DDT concentrations consistently in the early 1960s and exponential decreases in concentrations to the tops of cores (Van Metre and Callender, 1997; Van Metre, Callender, and Fuller,
1997). Total DDT concentrations were largest in the 35- to 40-, 40- to 45-, and 45- to 50-cm intervals in the "organics" core from site M2.40 indicating late-1950s and early 1960s. (Separate cores were used for organics [organochlorine pesticides, PAHs, and PCBs] and inorganics $\left[{ }^{137} \mathrm{Cs}\right.$ and major and trace elements] analyses from this site.)

One additional piece of information was available to provide an approximate date of the sediment. Dieldrin, an organochlorine pesticide, was detected in most samples in the M2.40 core down through the 60- to 65-cm interval (fig. 9). Dieldrin is a breakdown product 


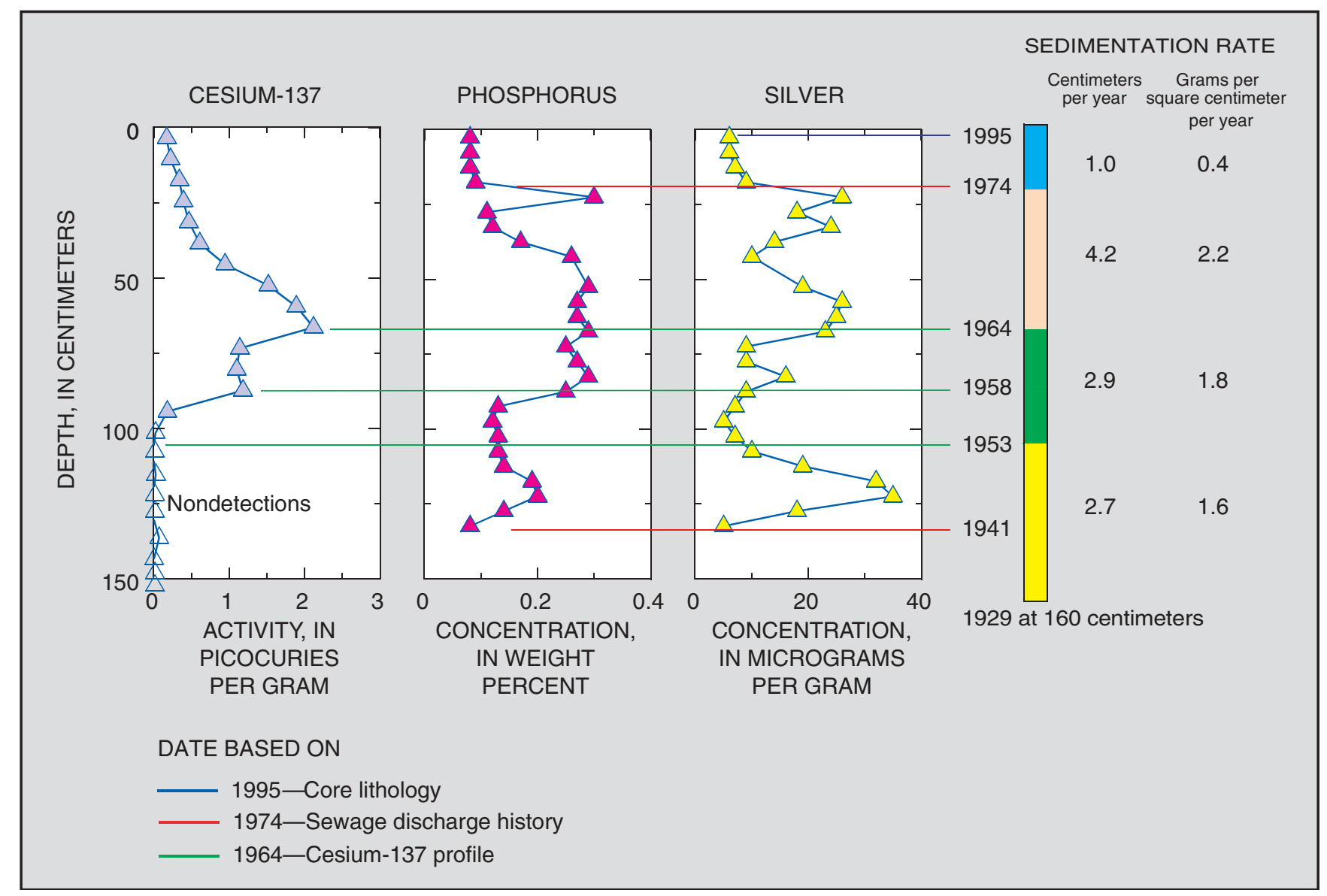

Figure 10. Age-depth indicators in Bay-13 core.

of aldrin. Aldrin was synthesized in 1948 and first produced commercially in 1951 ; therefore, the 60 - to $65-\mathrm{cm}$ interval cannot be older than the early 1950s. The total DDT peak is consistent with the ${ }^{137} \mathrm{Cs}$ peak at 40 to $44 \mathrm{~cm}$; however, the organics core extended to $72 \mathrm{~cm}$ before encountering pre-reservoir material compared to $48 \mathrm{~cm}$ in the inorganics core. Variability in lengths of cores and in thickness of lacustrine sediments between nearby sites is not uncommon (Van Metre, Callender, and Fuller, 1997). Variability between cores probably is caused by movement of the boat between core collections and uneven pre-reservoir surface elevations leading to uneven sedimentation and erosion. On the basis of the total DDT profile, dieldrin detections, linear sedimentation rates for the upper parts of the two cores, and relative lengths of the cores, the lacustrine sedimentary record in the organics core probably begins about 1940.

Samples from the MCL-4 core were not analyzed for ${ }^{137} \mathrm{Cs}$; however, the location of the site in deep water at the center of the lake and the total DDT profile in the core indicate a complete sedimentary record from 1929 until 1994 when the cores were collected (fig. 9). Lacustrine sediments in the MCL-4 organics core were 128 $\mathrm{cm}$ thick, and total DDT peaked in the 50- to $60-\mathrm{cm}$ interval at $5.9 \mu \mathrm{g} / \mathrm{kg}$. DDT and its breakdown products were not detected below $100 \mathrm{~cm}$, indicating that this core probably does date from 1929 .

Samples from the Bay-13 core were dated (fig. 10) on the basis of core lithology, ${ }^{137} \mathrm{Cs}$ results, and phosphorus and trace element trends in relation to historical discharges from the west lagoon. Dates for two deeper samples from the MCL-7 core in Cottonwood Bay were assigned on the basis of comparison to the Bay-13 core. The lacustrine sediment at MCL-7 was $84 \mathrm{~cm}$ thick compared to $161 \mathrm{~cm}$ in the ${ }^{137} \mathrm{Cs}$ core (and $160 \mathrm{~cm}$ in the organics core) at Bay-13. The first occurrence of ${ }^{137} \mathrm{Cs}$ in the Bay-13 core was in the 91- to 98-cm interval, a minor peak occurred in the $84-$ to 
91-cm interval, and the maximum concentration was in the 63- to 70-cm interval. Therefore, $98 \mathrm{~cm}$ was assigned a date of $1953,87.5 \mathrm{~cm}$ a date of 1958 , and $66.5 \mathrm{~cm}$ a date of 1964. A dark black layer with a strong hydrocarbon odor occurs at 13 to $25 \mathrm{~cm}$, and relatively large concentrations of phosphorus were measured in the 14- to $25-\mathrm{cm}$ interval in the MCL-7 core. Phosphorus concentrations, in weight percent, increased from 0.09 to 0.30 from the $15-$ to $20-\mathrm{cm}$ interval to the 20 - to $25-\mathrm{cm}$ interval in Bay-13 and increased from 0.08 to 0.21 from the $0-$ to $3-\mathrm{cm}$ interval to the $14-$ to $25-\mathrm{cm}$ interval in MCL-7. The change in phosphorus concentrations in the MCL-7 and Bay-13 cores provides a time marker matching the end of sewage effluent discharges to the west lagoon from NWIRP in 1974. Basing the 1974 date at $20 \mathrm{~cm}$ down core in Bay-13 on phosphorus concentrations and on cessation of sewage effluent discharges is supported by decreases in trace element concentrations at the same level in the core, for example silver (fig. 10). Large reductions in pointsource discharges containing metals to the west lagoon occurred in 1974. Cadmium, chromium, and copper concentrations decreased from 72 to $9.0 \mu \mathrm{g} / \mathrm{g}, 4,300$ to $550 \mu \mathrm{g} / \mathrm{g}$, and 180 to $62 \mu \mathrm{g} / \mathrm{g}$, respectively, between the 20 - to $25-\mathrm{cm}$ and $15-$ to $20-\mathrm{cm}$ intervals in the core. Six date-depth markers thus are available for the Bay-13 core: 1995 at $0 \mathrm{~cm}, 1974$ at $20 \mathrm{~cm}, 1964$ at $66.5 \mathrm{~cm}$, 1958 at $87.5 \mathrm{~cm}, 1953$ at $98 \mathrm{~cm}$, and 1929 at $160 \mathrm{~cm}$ (fig. 10). An additional date, 1941, was inferred from chemical changes in the core that probably are related to the opening of the NWIRP facility.

\section{Occurrence, Trends, and Sources of Metals}

Metals in Mountain Creek Lake come from natural as well as anthropogenic sources. Metals that are naturally introduced to the lake come from weathering of rocks, soil erosion, or dissolution of salts. Metals that are artificially introduced come from a variety of human activities. In the drainage of Mountain Creek Lake, these include industrial releases; urban runoff from roads, buildings, and parking lots; fallout from local and regional atmospheric sources; and agricultural runoff of pesticides.

The metallic elements can be categorized into two groups. Heavy metals are those with densities more than five times the density of water, and light metals are those with lesser densities. Heavy metals, which include cadmium, chromium, copper, lead, mercury, nickel, silver, and zinc, are frequently associated with industrial and urban sources and are the focus of the interpretations presented here. Additionally, this section discusses other selected major and trace elements, including the non-metallic trace elements arsenic and selenium.

\section{Metals in Stormwater}

Runoff from six storms was sampled at each of three sites on NAS and two sites on NWIRP during 1994-96; however, the same six storms were not sampled concurrently at all sites (Raines and others, 1997). Samples were collected by automated samplers and by hand-dipping and were composited over storm hydrographs to allow storm loads to be computed for selected constituents. Unfiltered water samples were extracted to obtain "total recoverable" metals concentrations.

Several metals were detected in stormwater samples from the five sites at NAS and NWIRP. The most commonly detected metals-iron, manganese, and zinc-were detected in all composite samples in which they were analyzed (iron and manganese not analyzed for all storms at some sites). Aluminum also was detected in a majority of the samples. Generally, the greater the TSS concentration, the greater the metals concentrations. This relation is expected because sediments contain much greater concentrations of metals than water. These analyses are of unfiltered water; therefore, the more sediment in the sample (larger TSS concentration), the larger the expected metals concentrations in the sample.

In addition to sampling unfiltered water during 1994-96, large-volume stormwater samples were collected and dewatered to obtain suspended sediment for direct chemical analysis in 1997 . Filtered $(0.5-\mu \mathrm{m}$ pore size) samples were collected for dissolved metal analyses concurrently with the suspended sediment samples. Suspended sediment samples were collected at the west and east lagoon outfalls from NWIRP (NWIRP-1 and NWIRP-2, respectively) and on the north fork of Cottonwood Creek. One storm was sampled at the east lagoon outfall. Two storms were sampled at the west lagoon outfall and the north fork of Cottonwood Creek; however, small sediment recovery in the west lagoon outfall samples led to a decision to composite sediment from the two storms to obtain more reliable analyses of metals concentrations. Sufficient mass was available in split samples from each of the two west lagoon storms for analysis of organic compounds (PAHs, organochlorine pesticides, and $\mathrm{PCBs}$ ). 
Metals concentrations in suspended sediment were highly variable with larger concentrations in samples from the NWIRP lagoons than in the north fork of Cottonwood Creek. Concentrations of selected heavy metals, including cadmium, chromium, copper, lead, mercury, and zinc, are notably larger in the lagoon samples relative to the urban (north fork) site on Cottonwood Creek.

As has been demonstrated elsewhere (for example, Meade, 1995), concentrations of heavy metals are much greater in suspended and bottom sediment than in filtered water. For example, the concentration of lead in three filtered stormwater samples from the NWIRP lagoons (one from the east lagoon and two from the west lagoon) were all less than $0.5 \mu \mathrm{g} / \mathrm{L}$ (or parts per billion). In comparison, the concentrations of lead in suspended sediment samples from the same storms were $370 \mu \mathrm{g} / \mathrm{g}$ (or parts per million [ppm]) in the east lagoon storm sample and $250 \mu \mathrm{g} / \mathrm{g}$ in the composite of suspended sediment samples from the two west lagoon storms. On a per-mass basis, the lead concentrations were at least 740,000 and 500,000 times greater in suspended sediments than in filtered water, respectively. Large ratios also occur for other heavy metals, for example zinc. Zinc in a filtered water sample from the west lagoon was $12 \mu \mathrm{g} / \mathrm{L}$ compared to $2,130 \mu \mathrm{g} / \mathrm{g}$ in a suspended sediment sample. Converting both to parts per million yields $0.012 \mathrm{ppm}$ in filtered water compared to $2,130 \mathrm{ppm}$ in suspended sediment or 178,000 times more zinc in the equivalent mass of sediment than in water.

Even though the dissolved concentrations are much smaller than the suspended concentrations, a much larger mass of water than sediment is transported to the lake by storms. The proportion of the load of metals transported to the lake in stormwater and associated with the suspended and dissolved phases can be evaluated for these sampled storms. The mass of metal in a liter of filtered stormwater is reported directly in micrograms per liter. The mass of metal in the suspended sediment in a liter of stormwater can be determined by multiplying the mass of metal per gram of sediment times the TSS, in grams per liter. TSS concentrations in the two storms sampled at the west lagoon outfall were 8.0 and $3.3 \mathrm{mg} / \mathrm{L}$ or 0.0080 and 0.0033 grams per liter $(\mathrm{g} / \mathrm{L})$. Averaging those two concentrations, because the suspended sediment metals analysis was a composite of sediment from the two storms, yields $0.0056 \mathrm{~g} / \mathrm{L}$. Multiplying TSS times the zinc concentration in the suspended sediment sample, $2,130 \mu \mathrm{g} / \mathrm{g}$, yields $12 \mu \mathrm{g} / \mathrm{L}$ of zinc in the suspended fraction of stormwater, equal to the $12 \mu \mathrm{g} / \mathrm{L}$ measured in the filtered fraction. Therefore, even though the concentration in sediment was 178,000 times greater, about the same mass load of zinc was moving to the lake in the water phase as was moving to the lake in the suspended sediment phase. A similar calculation for lead, $370 \mu \mathrm{g} / \mathrm{g}$ times $0.0056 \mathrm{~g} / \mathrm{L}$, yields an estimated $2.1 \mu \mathrm{g} / \mathrm{L}$ in the sediment phase versus less than $0.5 \mu \mathrm{g} / \mathrm{L}$ in the filtered water. Even though the TSS concentrations are small, at least 80 percent of the lead and about 50 percent of the zinc were transported in the suspended phase.

\section{Metals in Lake Water}

Lake water samples were collected from four sites (fig. 1) on October 12, 1994. Major and trace element concentrations were measured in filtered $(0.45-\mu \mathrm{m}$ pore size $)$ water. Metals detected were barium, iron, lithium, strontium, and zinc (Jones and others, 1997, p. I-33). Except for the one detection of zinc at site MCL-12, none of the industrial heavy metals with elevated concentrations in suspended sediments (cadmium, chromium, copper, lead, mercury, and zinc) were detected in lake water.

\section{Metals in Sediment}

Metal concentrations vary greatly in bottom sediment from Mountain Creek Lake. For example, chromium concentrations in Phase I samples range from $69 \mu \mathrm{g} / \mathrm{g}$ at site MCL-11 to 4,400 $\mu \mathrm{g} / \mathrm{g}$ in a deeper interval from site Bay-13 (Jones and others, 1997; p. I-25, I-22). Ratios of concentrations in White Rock Lake in Dallas, in MCL-7 (central bay), and in MCL-12 (NAS inlet) to mean concentrations of mainlake reference sites (table 4) were computed to show which metals, if any, have elevated concentrations in Mountain Creek Lake bottom sediment (fig. 11). Ratios were computed for selected metals commonly associated with urban and industrial sources. Main-lake reference concentrations are the mean concentrations of six sites grouped by cluster analysis (table 4 ). White Rock Lake is considered typical of urban-influenced lakes in the Dallas area. MCL-7 is influenced by runoff from the west lagoon and NWIRP. MCL-12 is influenced by runoff from the NAS hanger area, roads, parking areas, and fuel farm.

As a general guideline, a ratio greater than 2 (concentration more than double the reference concentration) is considered an indication of an elevated 

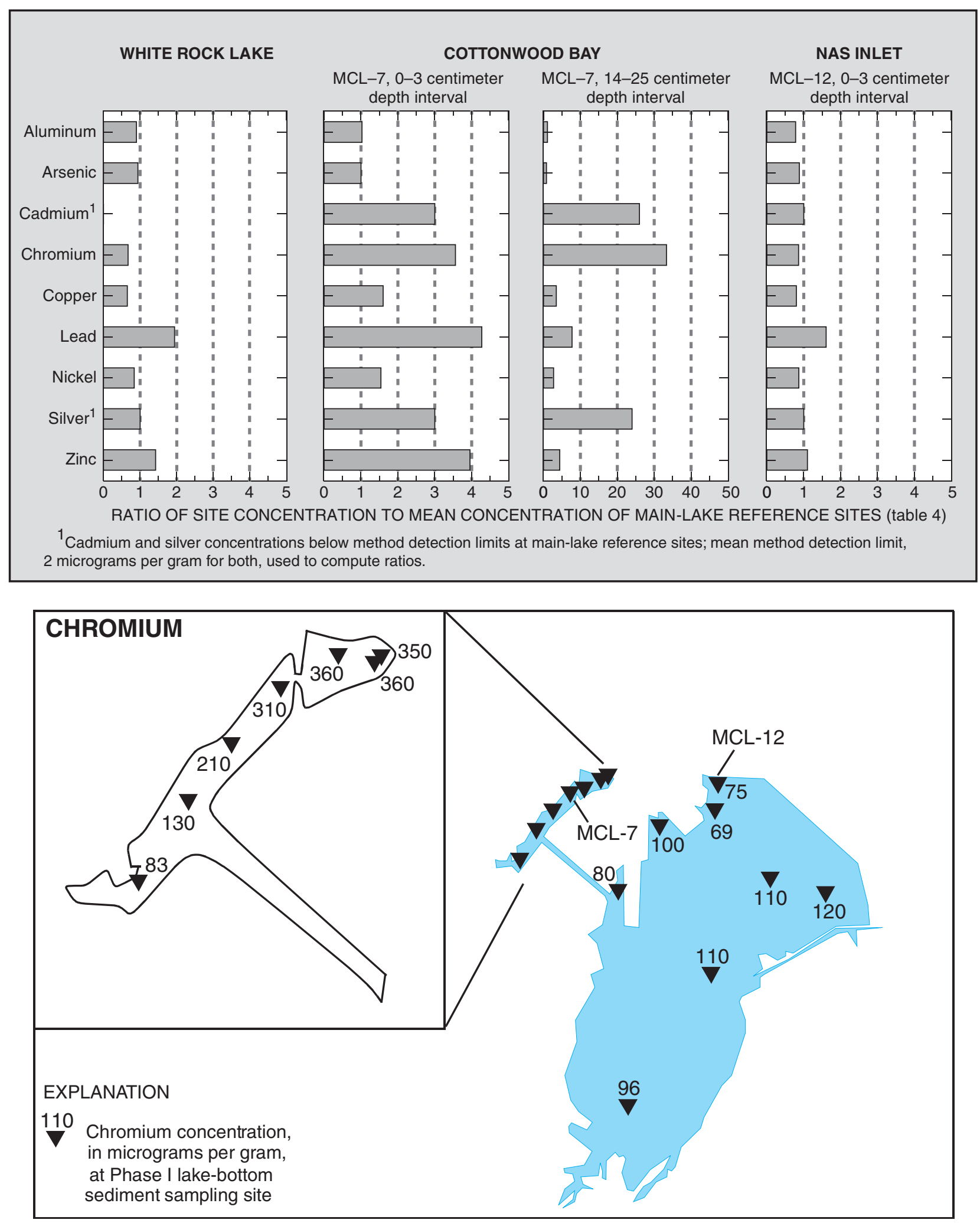

Figure 11. Ratios of Phase I metal concentrations in lake bottom sediment at selected sites to mean concentrations of main-lake reference sites. 
concentration, and a ratio greater than 10 is considered an indication of a greatly elevated concentration. Aluminum concentrations are shown (fig. 11) because aluminum is a major element in clay minerals and thus can be used to normalize sediment data for comparison of trace metal concentrations among samples (Van Metre and Callender, 1996). Aluminum concentration ratios are about 1.0, indicating slightly more aluminum at reference sites than at the other sites. The range in aluminum concentration ratios also indicates that elevated concentrations of trace metals at some sites are not a sampling artifact related to greater clay content in those samples.

In general, ratios are near unity in the samples from site MCL-12 and White Rock Lake (fig. 11), suggesting these sites do not have elevated metals concentrations. Ratios greater than unity for lead and zinc at White Rock Lake and lead at MCL-12 are exceptions. Lead enrichment at both sites probably results from urban and, in particular, automobile-related lead sources. Lead concentrations in urban lakes greatly increased coincident with urbanization and lead use in gasoline prior to the mid-1970s (Callender and Van Metre, 1997). Although concentrations have decreased substantially since then, they remain about double pre-urban levels in many urban lakes including White Rock Lake. Ratios greater than 2 and, in one case, as large as 33 were computed for the samples from site MCL-7, with larger ratios in the $14-$ to $25-\mathrm{cm}$ interval than in the 0 - to $3-\mathrm{cm}$ interval. Of the eight metals shown in figure 11, only arsenic, with concentration ratios of 0.92 to 1.10 , was not elevated in any of the three MCL samples. Copper, nickel, and zinc are elevated in MCL-7 (0 to $3 \mathrm{~cm}$ and 14 to $25 \mathrm{~cm}$ ), with maximum ratios of 3.5, 2.7, and 4.4, respectively. Concentrations of cadmium, chromium, and silver were greatly elevated in the 14 - to $25-\mathrm{cm}$ interval from MCL-7, with ratios of 26,33 , and 24 , respectively. The actual ratio for silver could be greater than 24 because silver was not detected at an MRL of $2 \mu \mathrm{g} / \mathrm{g}$ at any site outside of Cottonwood Bay but was $48 \mu \mathrm{g} / \mathrm{g}$ in the 14- to $25-\mathrm{cm}$ interval from MCL-7. The ratio of 24 is based on the MRL of $2 \mu \mathrm{g} / \mathrm{g}$ at the reference sites.

Ratios of concentrations at four Phase II sites to main-lake reference concentrations were computed for selected metals (fig. 12) that showed elevated concentrations relative to reference concentrations at Phase I sites, with the exception of cadmium (not measured in Phase II) and with the addition of mercury (Jones and others, 1997, p. II-22). Sites compared to reference concentrations were M2.22 (west bay) near the mouth of Cottonwood Creek, M2.11 (central bay) near site MCL-7 in front of the west lagoon outfall, M2.2 (east bay) near the east lagoon outfall from NWIRP, and M2.40 (NAS inlet). As in figure 11, main-lake reference concentrations are the mean concentrations of six sites grouped by cluster analysis (table 4).

Phase II metals compared in figure 12 confirm several conclusions from the Phase I comparison. Concentrations of chromium, lead, mercury, and zinc were elevated in the central and eastern parts of Cottonwood Bay. Chromium, lead, and zinc enrichment factors for surficial sediments (fig. 12) are similar to those for Phase I (fig. 11). Most metals were not elevated at M2.40, the NAS inlet, with the possible exceptions of lead and mercury. The ratio of lead at M2.40 to the mean main-lake reference for lead is 1.9 , and the ratio of mercury is 2.0. Mercury also was somewhat elevated at the western end of Cottonwood Bay (M2.22; ratio of 1.9) and was elevated in the east bay (M2.2; ratio of 5.7) and the central bay (M2.11; ratio of 7.7).

Selenium was identified by the Texas Department of Health as a possible human health concern in fish-tissue samples (Kirk Wiles, Texas Department of Health, written commun., 1996). Selenium concentrations were measured in 19 Phase II surficial sediment samples and ranged from 0.5 to $1.0 \mu \mathrm{g} / \mathrm{g}$ (Jones and others, 1997). The narrow range and lack of a distinct spatial pattern as a function of land use indicates that the selenium in sediments is from natural sources.

The spatial pattern in chromium concentrations and other heavy metals with elevated concentrations was similar-larger concentrations in Cottonwood Bay, with the largest near the west lagoon outfall, and smaller concentrations in the main lake and NAS inlet. Concentrations of the four heavy metals in Phase II bottom sediment samples are summarized in table 5 for five areas of the lake. Summary statistics were computed for surficial samples $(0$ to $3 \mathrm{~cm})$ in each area. Concentrations are largest in the eastern and central parts of Cottonwood Bay, decrease in the west bay and the canal, and are smallest in the main lake. The main lake includes the NAS inlet because concentrations in the NAS inlet are not appreciably greater than in other parts of the main lake. As shown by the site comparisons (fig. 12), concentrations of these metals in the central and east bay are 2 to 4 times greater than in the main part of Mountain Creek Lake.

Trends in chromium, lead, and zinc in sediment cores (fig. 13) in the main lake (MCL-4) and NAS 

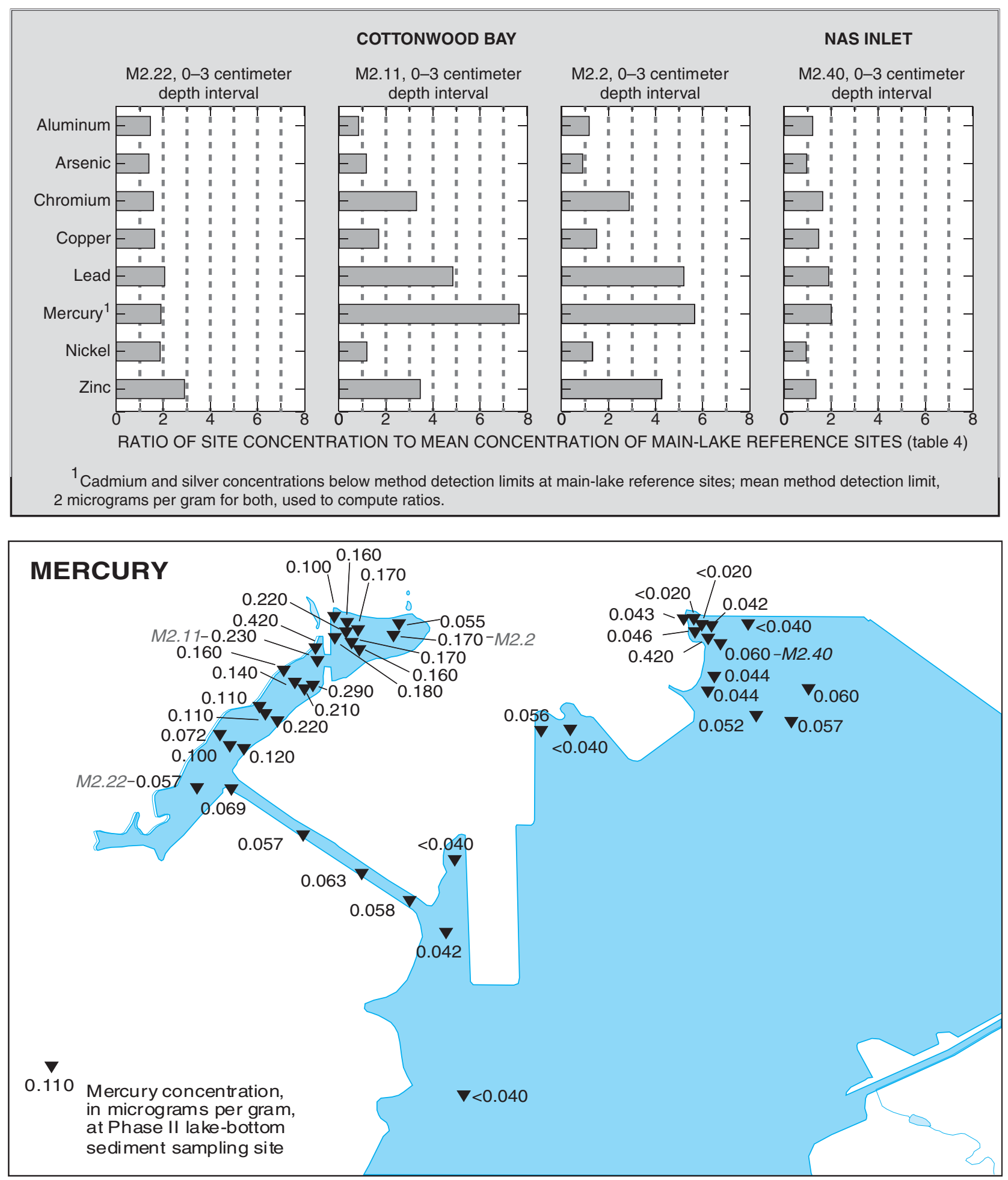

Figure 12. Ratios of Phase II metal concentrations in lake bottom sediment at selected sites to mean concentrations of main-lake reference sites. 


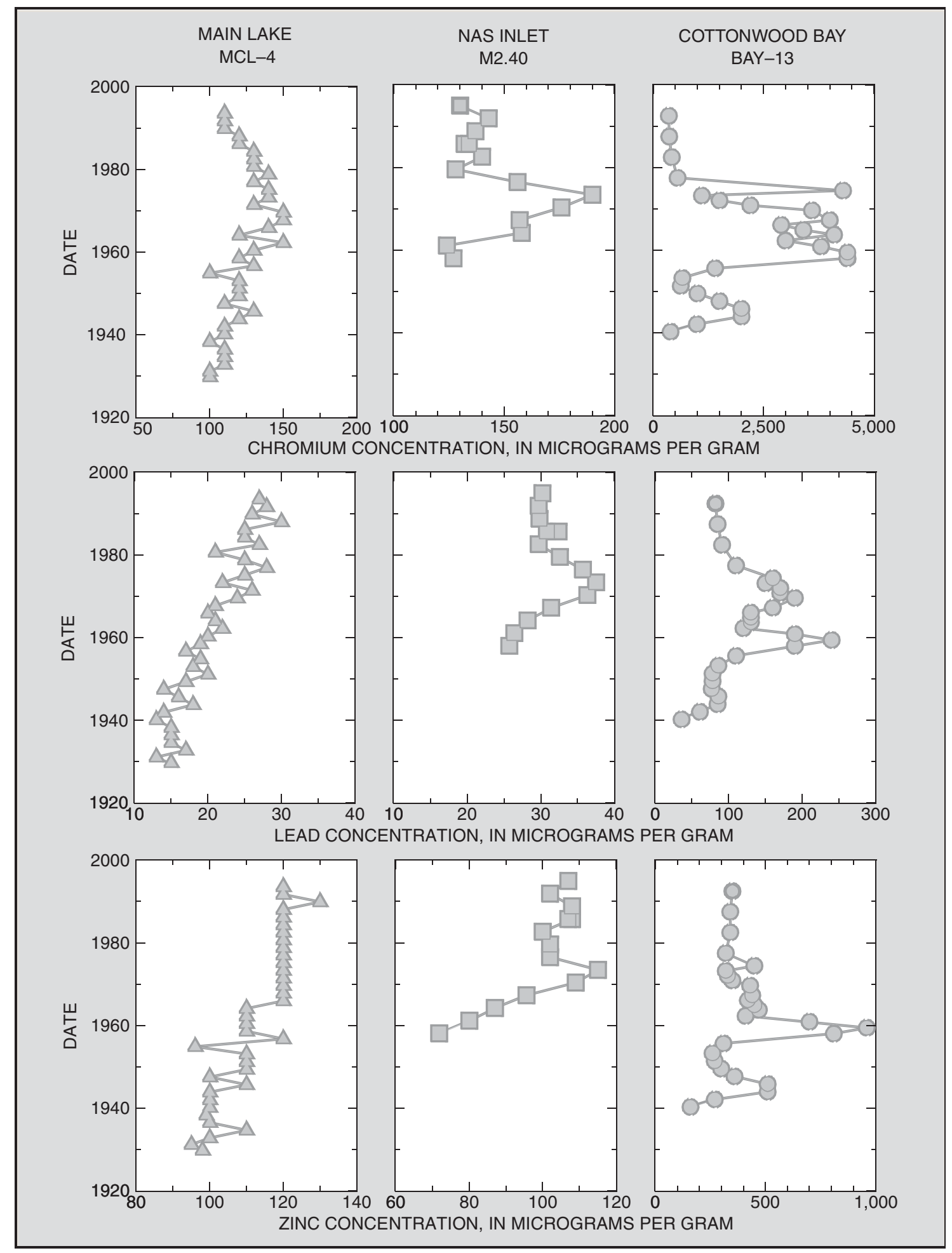

Figure 13. Trends in chromium, lead, and zinc concentrations in MCL-4, M2.40, and Bay-13 cores. 
Table 5. Summary of selected metal concentrations in sediment

[In micrograms per gram; s.d., standard deviation; NAS, Naval Air Station]

\begin{tabular}{lccccc}
\hline Metal & $\begin{array}{c}\text { Cottonwood Bay } \\
\text { mean (s.d.) } \\
\text { of } \mathbf{9} \text { samples }\end{array}$ & $\begin{array}{c}\text { Cottonwood Bay } \\
\text { mean (s.d.) } \\
\text { of } \mathbf{9} \text { samples }\end{array}$ & $\begin{array}{c}\text { Cottonwood Bay } \\
\text { mean (s.d.) } \\
\text { of } \mathbf{4} \text { samples }\end{array}$ & $\begin{array}{c}\text { Canal } \\
\text { mean (s.d.) } \\
\text { of } \mathbf{4} \text { samples }\end{array}$ & $\begin{array}{c}\text { Main lake } \\
\text { (includes NAS inlet) } \\
\text { mean (s.d.) } \\
\text { of 18 samples }\end{array}$ \\
\hline Chromium & $240(19)$ & $210(53)$ & $140(40)$ & $150(4.0)$ & $100(41)$ \\
Lead & $90(10.4)$ & $74(20.6)$ & $54(14.5)$ & $30(5.2)$ & $23(10.3)$ \\
Mercury & $.15(.048)$ & $.21(.099)$ & $.09(.028)$ & $.06(.005)$ & $.05(.007)$ \\
Zinc & $330(79)$ & $350(54)$ & $240(86)$ & $130(26)$ & $120(56)$ \\
\hline
\end{tabular}

inlet (M2.40) generally are similar to trends in White Rock Lake (Van Metre and Callender, 1997) and in urban reservoirs in Georgia and Virginia (for lead, Callender and Van Metre, 1997; for chromium and zinc, Edward Callender, U.S. Geological Survey, unpub. data, 1997). Characteristics of these trends are maximum chromium concentrations in the 1960s and early 1970s, lead peaks in the mid-1970s coincident with maximum use of lead in gasoline, and increases in zinc concentrations with urban growth. The notable exception to these trends is the lack of a 1970s lead peak in the mainlake core (MCL-4). Lead concentrations in the mainlake core increase from the 1930s to the 1970s, as observed in other urbanizing areas; however, the lack of a decrease after the introduction of unleaded gasoline in the mid-1970s has not been observed elsewhere (Callender and Van Metre, 1997) and suggests some other source or sources of lead could be contributing to the continuing increase. The decreasing trends in both the NAS inlet (M2.40) and Cottonwood Bay (Bay-13) indicate that the Navy facilities are not the source of recent increases in lead concentrations in the main lake.

The Bay-13 core from Cottonwood Bay shows very large peaks in all three metals in comparison to concentrations in the other two cores (note the scale differences on graphs in fig. 13). Maximum lead and zinc concentrations are about 10 times greater than at the other sites, and the maximum chromium concentration is about 20 times greater. The largest concentrations of these three metals are in a sample deposited in about 1960. Smaller peaks occur in the early 1940s and the early 1970s. Lead and chromium concentrations decrease substantially after 1974 with the reduction in point-source discharges to the west lagoon; zinc concentrations have remained relatively stable since the mid-1960s.
All seven heavy metals that had elevated concentrations in Phase I surficial sediments in Cottonwood Bay (fig. 11) have pronounced historical trends in the Bay-13 core from Cottonwood Bay (fig. 14). Cadmium, as was the case for chromium, lead, and zinc, peaked in about 1960, was high throughout the 1960s, and had secondary peaks in the mid-1940s and mid-1970s. Neither copper nor nickel had a large peak in 1960 or a secondary peak in the 1940s. Both had maximum concentrations during the mid- to late-1960s and had slightly smaller peaks in about 1974 . Silver had yet another temporal pattern with three large peaks in the early 1940s, mid-1960s, and mid-1970s. The largest silver peak was $37 \mu \mathrm{g} / \mathrm{g}$ in the early 1940s. Silver was not detected at an MRL of $2 \mu \mathrm{g} / \mathrm{g}$ in any samples from White Rock Lake (P.C. Van Metre, U.S. Geological Survey, unpub. data, 1997) or in any samples from the main part of Mountain Creek Lake (Jones and others, 1997). The differences in trends between metals indicate some differences in input histories.

Mercury was not measured in Phase I bottom sediment samples including the Bay-13 core; however, it was measured in Phase II samples including surficial sediments in Cottonwood Bay and in the M2.40 gravity core from the NAS inlet (fig. 15). Mercury concentrations are increasing in the NAS inlet, which is consistent with regional increases in mercury observed in cores from other reservoirs (Van Metre, Mahler, and Callender, 1997) and lakes (Swain and others, 1992).

\section{Metals in Fish}

Composite samples of fish-liver tissue from either four or five fish from three areas of the lake were analyzed for major and trace elements during Phase I (Jones and others, 1997, p. I-42). Several common 


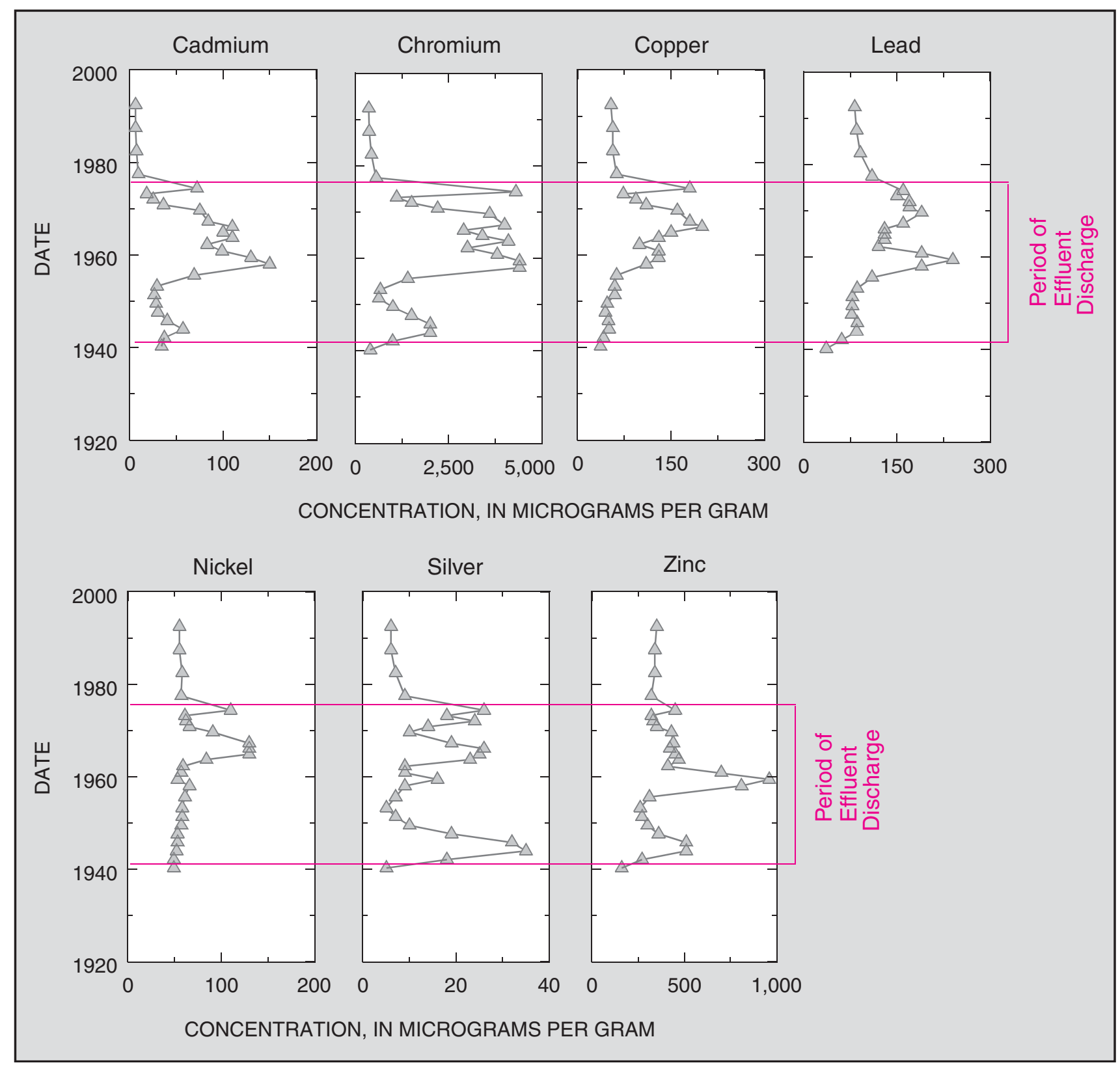

Figure 14. Trends in heavy metals concentrations in Cottonwood Bay as indicated by the Bay-13 core.

industrial heavy metals - copper, cadmium, chromium, lead, nickel, and zinc-were detected in bass and common carp liver tissue samples (fig. 16). Iron, manganese, and strontium also were detected. Neither the detections nor concentrations of specific elements in bass and common carp liver tissue indicate a spatial pattern for the elements in the reservoir.

Fillet subsamples from individual fish were analyzed for major and trace elements during Phase II
(Jones and others, 1997, p. II-40). Commonly detected elements in Phase II tissue samples were chromium, copper, mercury, selenium, and zinc (fig. 16). Selenium concentrations generally were larger than those of other "bioavailable" trace elements (fig. 16), a group that includes arsenic, mercury, and selenium. These three trace elements are termed bioavailable because they accumulate in the axial muscles of fish and often occur in fillets at concentrations comparable to whole-body 


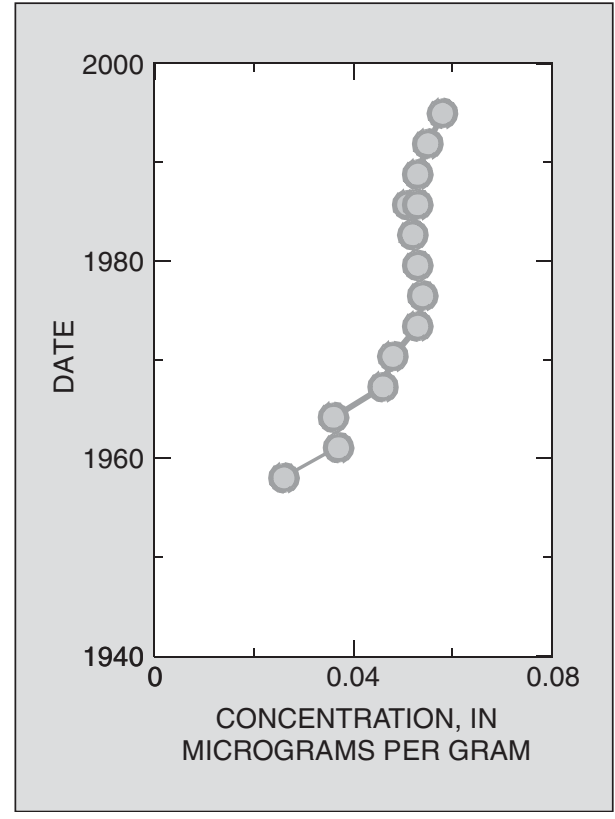

Figure 15. Trends in mercury concentrations in the NAS inlet as indicated by the M2.40 core.

concentrations of the same species (Schmitt and Finger, 1987). Median selenium concentrations by fish type ranged from 1.2 milligrams per kilogram $(\mathrm{mg} / \mathrm{kg})$ in channel catfish fillets to $2.4 \mathrm{mg} / \mathrm{kg}$ in common carp fillets. The median selenium concentration in whole-body, eviscerated channel catfish was only $0.18 \mathrm{mg} / \mathrm{kg}$ greater than the average fillet concentration for the same species. Concentrations of these bioaccumulating trace elements in fish tissue reportedly are strongly associated with sediment concentrations and less so with overlying water concentrations (Eisler, 1985). Selenium is the only trace element in edible fish tissue from Mountain Creek Lake for which the Texas Department of Health has expressed concern with respect to human consumption of fish (Kirk Wiles, Texas Department of Health, written commun., 1996).

\section{Sources of Metals}

Many of the heavy metals discussed in the previous sections have industrial uses (Hem, 1985). Cadmium is used for electroplating and for pigments used in paint, printing ink, and plastics. It also is used as a stabilizer for PVC plastic and in electrical batteries. Chromium is used in a variety of industrial applications including metal plating. Copper is used for a variety of applications including pipes and wiring. Nickel is used in stainless steel and other corrosion-resistant alloys.
Silver is used extensively in photography and is a common minor constituent of industrial wastes. Zinc is used in metallurgy, principally as a constituent of brass or bronze, and for galvanizing. It also is used in rubber and as a white pigment in paint. The use of lead that has had the greatest environmental effect was the addition of tetraethyl lead to gasoline before the mid-1970s.

From 1941 until the late-1950s, the west lagoon was open directly to Cottonwood Bay along the western side of the north-south causeway and bridge across the bay. An earth berm with two 1.3-m (48-inch) pipes open to the bay was installed in the late-1950s to create a settling pond that is the present west lagoon. In 1971 an oil-spill recovery system was built across the southern end of the lagoon. As of 1998, water from the west lagoon reached Cottonwood Bay only during storms that resulted in flow through the stormwater outflow pipes from the west lagoon to Cottonwood Bay.

An additional factor could affect sedimentation and contaminant movement into Cottonwood Bay. The natural channel of Cottonwood Creek crossed what is now the main runway of NAS before 1949. During 1949-50, fill was used to extend the main runway and expand NAS, closing off the natural outflow from Cottonwood Creek. The canal connecting Cottonwood Bay to the lake was dug at that time to provide an outlet for flow from Cottonwood Creek. Therefore, the central and eastern parts of Cottonwood Bay would have received sediment from all of the Cottonwood Creek watershed before 1950. After 1950, the central and east bay areas became a "dead end" embayment with only the immediate areas of NAS and NWIRP draining to them.

To indicate the association between metals concentrations in sediment of the west lagoon and Cottonwood Bay, thus the likelihood of the west lagoon as a source of the metals in Cottonwood Bay, concentrations of selected metals in sludge samples from the west lagoon (EnSafe/Allen \& Hoshall, 1996a), in suspended sediment samples from the west lagoon outfall (NWIRP-1), and in bottom sediment samples from Cottonwood Bay are compared to mean concentrations of main-lake reference sites (fig. 17). The comparisons indicate that (1) heavy metals generally are at greatly elevated concentrations in the west lagoon sediment, and (2) the same heavy metals also are at elevated concentrations in Cottonwood Bay sediment (fig. 17).

Historical point-source discharges are a source of heavy metals to the west lagoon. Much of the waste disposed of in the west lagoon during 1941-74 (table 3) 


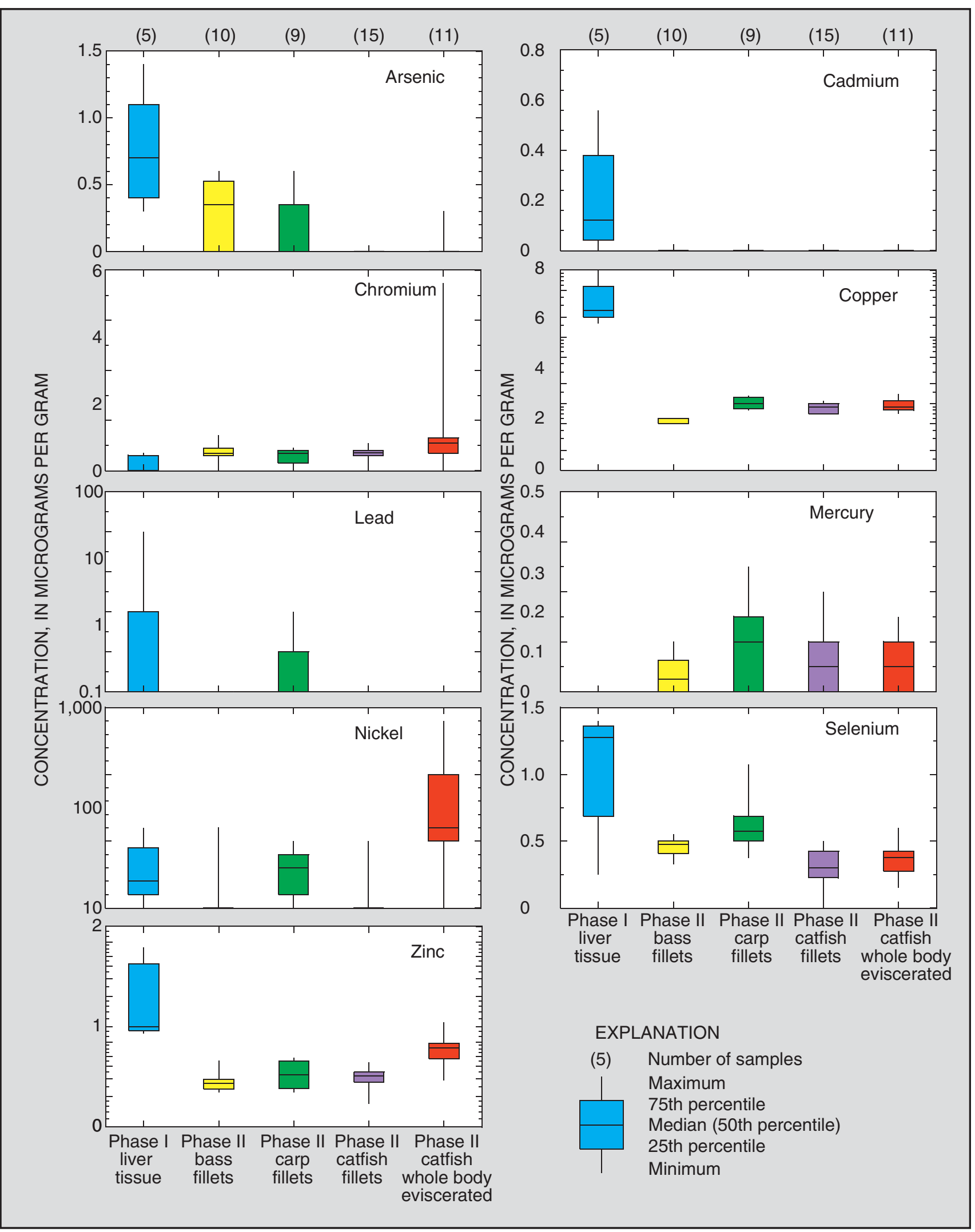

Figure 16. Distribution of metal concentrations in fish tissues, Mountain Creek Lake. 


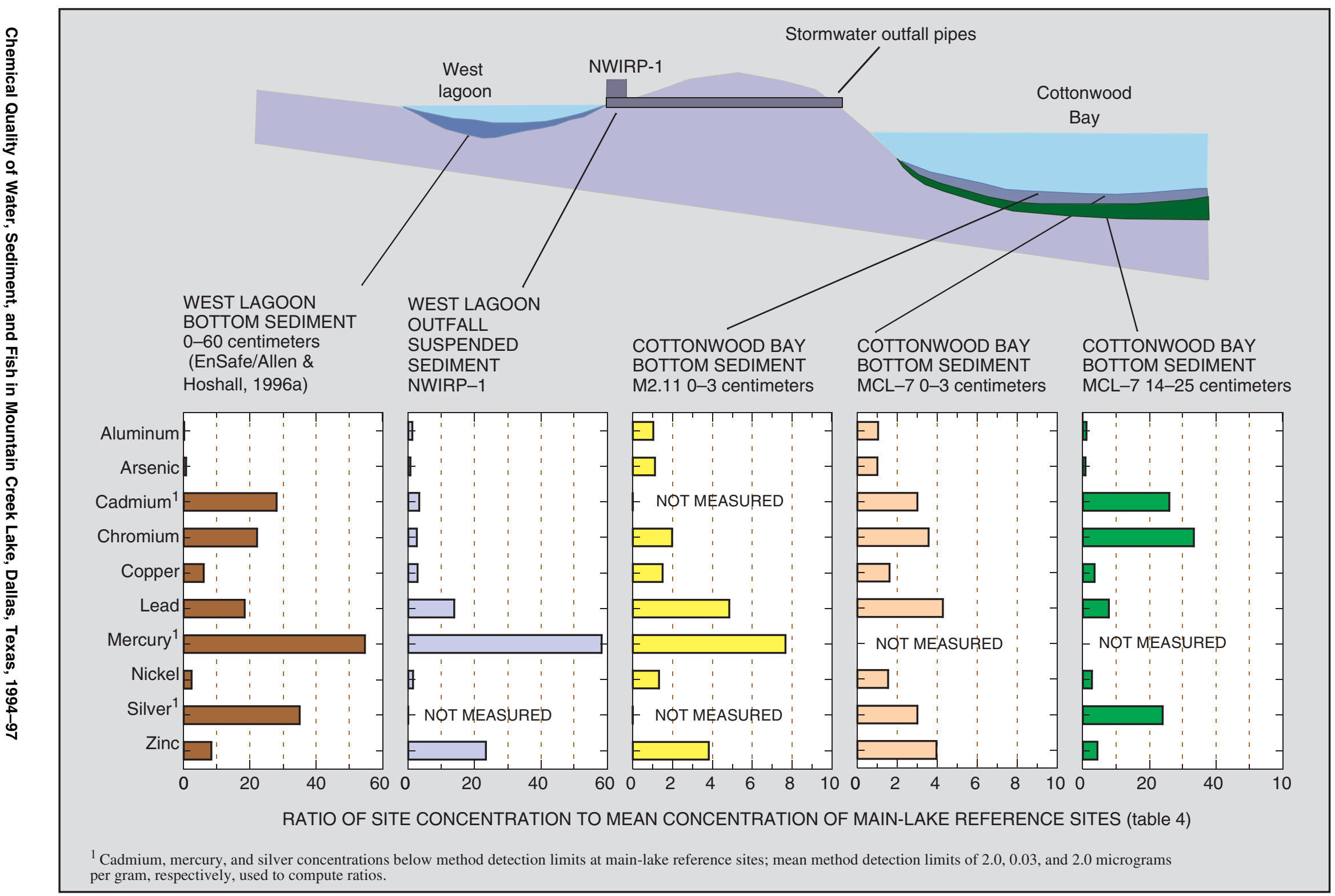

Figure 17. Ratios of lake-bottom sediment and suspended sediment metal concentrations in the west lagoon and Cottonwood Bay to mean concentrations of mean-lake reference sites. 
was from the plating shops and likely contained the metals that were found at elevated concentrations in the lagoon and Cottonwood Bay sediment. The greatly elevated mercury concentrations in bottom sediment in the west lagoon and in suspended sediment in the west lagoon outfall and the elevated concentrations in bottom sediment in Cottonwood Bay cannot be attributed to regional atmospheric sources.

The primary source of the elevated levels of heavy metals in sediment in east and central Cottonwood Bay is the west lagoon on NWIRP. This conclusion is based on the following evidence:

1. There is spatial proximity between the lagoon outfall and the sites of largest metal concentrations in Mountain Creek Lake bottom sediment; and concentrations decrease with distance from the outfall.

2. Documented historical discharges of metals to the west lagoon coincide temporally with large metal concentrations identified in lake sediment cores.

3. Elevated concentrations of the same metals are in bottom sediments in the west lagoon and in suspended sediments in stormwater flowing from the west lagoon into Cottonwood Bay.

4. Stormwater runoff and historical point-source discharges provide logical transport mechanisms from the lagoon to the bay.

5. Urban sources represented by sediment from the western end of Cottonwood Bay, bottom sediment from White Rock Lake, and bottom and suspended sediment from Cottonwood Creek have much smaller concentrations of heavy metals and cannot account for the concentrations in Cottonwood Bay sediments.

Concentrations of heavy metals in the NAS inlet are similar to those of main-lake and urban reference sites and indicate that large releases of metals from the NAS to Mountain Creek Lake have not occurred.

\section{Occurrence, Trends, and Sources of Volatile Organic Compounds}

VOCs present in the environment come from a variety of sources. The two categories of VOCs that are of concern at Mountain Creek Lake are those contained in fuels (for example, the BTEX compounds- benzene, methylbenzene [toluene], ethylbenzene, and xylenes) and chlorinated solvents (for example, TCE). The VOCs from fuels present on the Navy facilities are primarily from spills related to storage and refueling of aircraft and motor vehicles, and the VOCs from chlorinated solvents present are primarily from leaks in degreasing tanks (EnSafe/Allen \& Hoshall, 1996a, b).

The major components of gasoline are the saturated hydrocarbons-paraffins and alkanes. Other components in gasoline include the unsaturated hydrocarbons-olefins, aromatics, acetylenes, and PAHs. Although gasoline mixtures vary greatly, aromatics such as the BTEX compounds make up about 30 to 35 percent of the gasoline mixture, and paraffins usually make up more than 50 percent. Oxygenates such as methyl tert-butyl ether (MTBE) can contribute as much as 15 percent of the volume of the gasoline mixture.

Because of the greater solubility of BTEX compounds, they can compose more than 60 percent of the mass that goes into solution when gasoline is mixed with water (Barbaro and others, 1992). MTBE solubilities are 1 to 2 orders of magnitude larger than solubilities of BTEX compounds.

Chlorinated-solvent volatilities often result in their quick removal from surface-water bodies, primarily by evaporation. Measured and estimated half-lives for the chlorinated compounds of interest at Mountain Creek Lake, dichloroethene, TCE, tetrachloroethene, trichloroacetic acid, and vinyl chloride, range from as little as 3 hours to as much as 25 days (Howard, 1990). Chlorinated-solvent solubilities make the compounds a major concern in ground water because they quickly pass through soils because of their low adsorption coefficients (Howard, 1990).

\section{VOCs in Stormwater}

Fuel-related and chlorinated VOCs were detected in stormwater samples collected at NAS and NWIRP sites (Raines and others, 1997). The most commonly detected compounds at NAS sites were fuel-related VOCs, and the most commonly detected compounds at NWIRP sites were chlorinated solvents (fig. 18). Although fuel-related VOCs were more common at NAS sites, some chlorinated compounds also were detected at NAS -1 . Chlorinated compounds occur as soil and ground-water contaminants near NAS-1 (EnSafe/Allen \& Hoshall, 1996b). Fuel-related compounds were the only VOCs detected in stormwater at NAS-2 and NAS-3, except methylene chloride and 


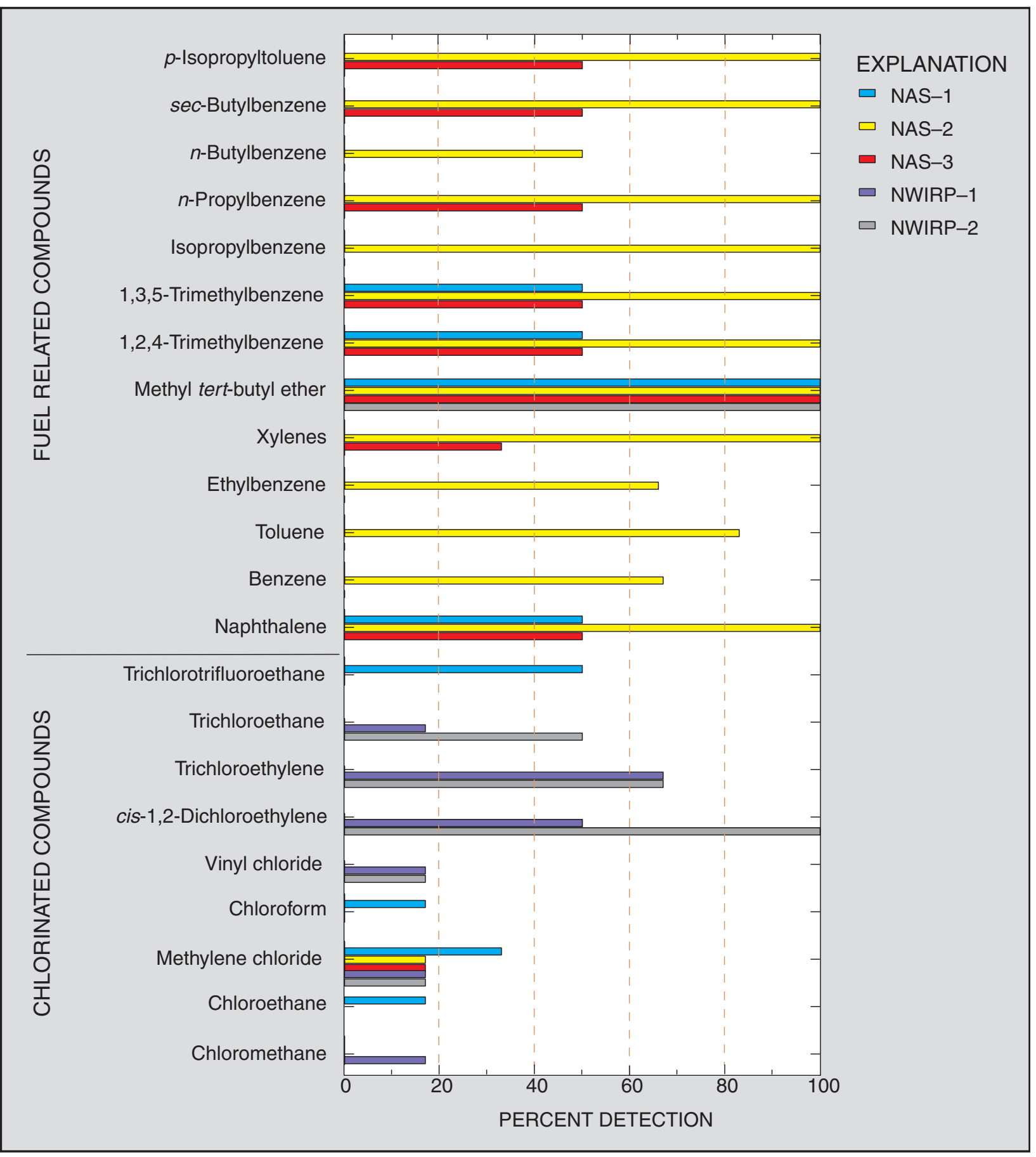

Figure 18. Percent detections of volatile organic compounds in composite samples collected at the fixed stormwater sites, Naval Air Station and Naval Weapons Industrial Reserve Plant.

acetone (NAS-2 only). BTEX compounds were detected for all six storms at NAS-2 (fig. 19). Xylenes were the only BTEX compounds detected at NAS-3, but several other fuel-related compounds were detected at this site. MTBE was analyzed only in storms 5 and 6 and was detected in samples from both storms at all NAS sites.

Chlorinated compounds were detected in four storms at the west lagoon outfall (NWIRP-1) and in five storms at the east lagoon outfall (NWIRP-2) (fig. 18). 


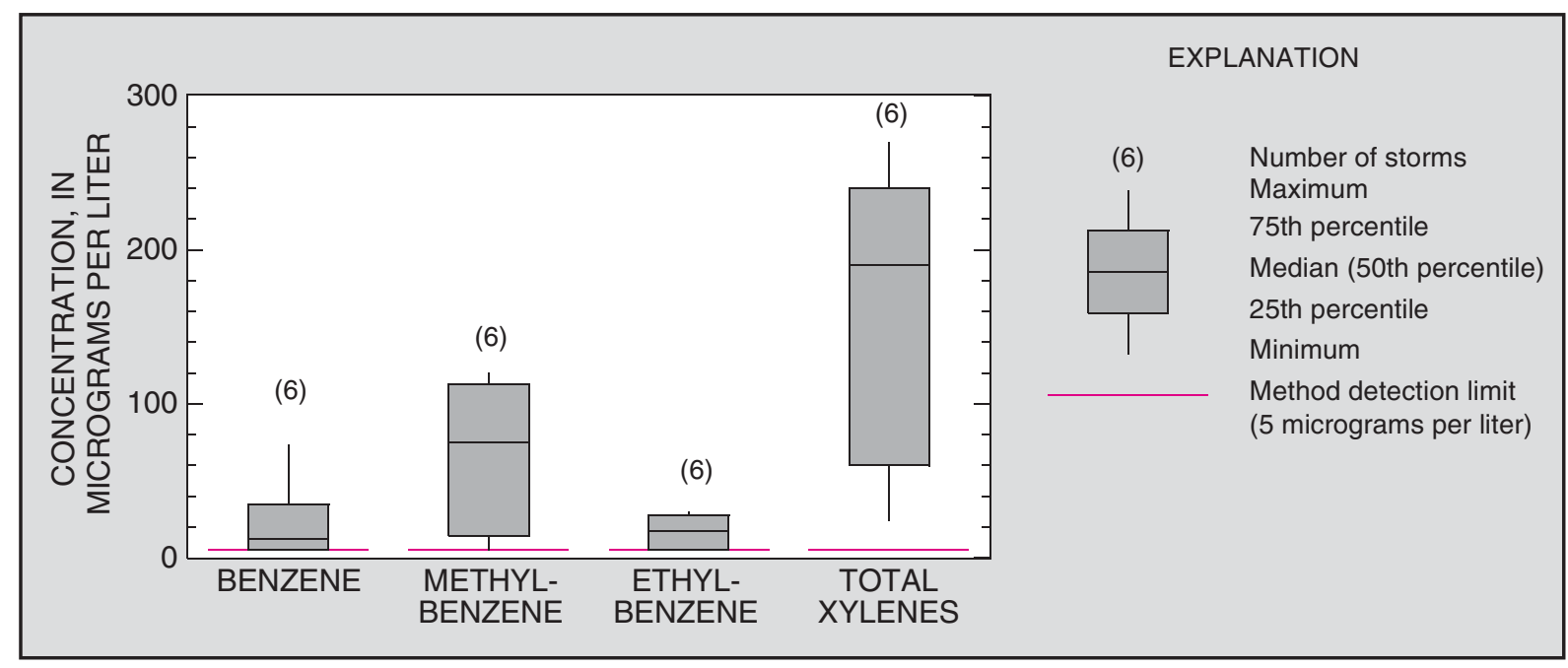

Figure 19. Distribution of BTEX compound concentrations detected at NAS-2 stormwater site.

MTBE was detected in all samples from both storms (storms 5 and 6) at NWIRP-2.

Minimum and maximum VOC concentrations and percent detections at the Navy facilities were compared to VOCs in stormwater from industrial sites in the Dallas-Fort Worth area that were measured as part of the National Pollutant Discharge Elimination System (NPDES) Program (table 6) (Baldys and others, 1998). The NPDES samples are from seven storms at each of
10 sites, all of generally similar drainage size as the Navy sites. Sampling methods of the two studies were similar, and the analytical method for VOCs was the same for the last two storms at the Navy sites. Maximum concentrations of the BTEX compounds and MTBE are 1 to 2 orders of magnitude larger at the Navy sites than at the NPDES sites. All of the maximum concentrations at the Navy sites occurred at NAS-2. Conversely, maximum concentrations of the ethene

Table 6. Comparison of volatile organic compound concentrations at the Navy sites, Dallas, Texas, and at industrial sites in the Dallas-Fort Worth area

[NWIRP, Naval Weapons Industrial Reserve Plant; NAS, Naval Air Station; $\mu \mathrm{g} / \mathrm{L}$, micrograms per liter; NPDES, National Pollutant Discharge Elimination System; <, less than]

\begin{tabular}{|c|c|c|c|c|c|c|}
\hline \multirow[b]{2}{*}{$\begin{array}{l}\text { Volatile organic } \\
\text { compound }\end{array}$} & \multicolumn{3}{|c|}{ NWIRP and NAS } & \multicolumn{3}{|c|}{ NPDES $^{1}$} \\
\hline & $\begin{array}{c}\text { Minimum } \\
\text { concentration } \\
(\mu \mathrm{g} / \mathrm{L})\end{array}$ & $\begin{array}{c}\text { Maximum } \\
\text { concentration } \\
(\mu \mathrm{g} / \mathrm{L})\end{array}$ & $\begin{array}{c}\text { Percent } \\
\text { detection }\end{array}$ & $\begin{array}{c}\text { Minimum } \\
\text { concentration } \\
(\mu \mathrm{g} / \mathrm{L})\end{array}$ & $\begin{array}{c}\text { Maximum } \\
\text { concentration } \\
(\mu \mathrm{g} / \mathrm{L})\end{array}$ & $\begin{array}{c}\text { Percent } \\
\text { detection }\end{array}$ \\
\hline Benzene & $<0.2$ & 73 & 20 & $<0.2$ & 0.6 & $<10$ \\
\hline Toluene & $<.2$ & 120 & 20 & $<.2$ & 1.8 & 17 \\
\hline Ethylbenzene & $<.2$ & 30 & 20 & $<.2$ & 1.5 & $<10$ \\
\hline Total xylenes & $<.2$ & 270 & 27 & $<.2$ & 10 & 16 \\
\hline Methyl tert-butyl ether & $<1$ & 55 & 80 & $<1$ & 5.4 & $<10$ \\
\hline Trichloroethene & $<.2$ & 25 & 40 & $<.2$ & 28 & 13 \\
\hline cis-1,2-dichloroethene & $<.2$ & 3.5 & 13 & $<.2$ & 1,200 & 22 \\
\hline Vinyl chloride & $<.2$ & 9 & 13 & $<.2$ & 110 & $<10$ \\
\hline
\end{tabular}

\footnotetext{
${ }^{1}$ Baldys and others, 1998.
} 


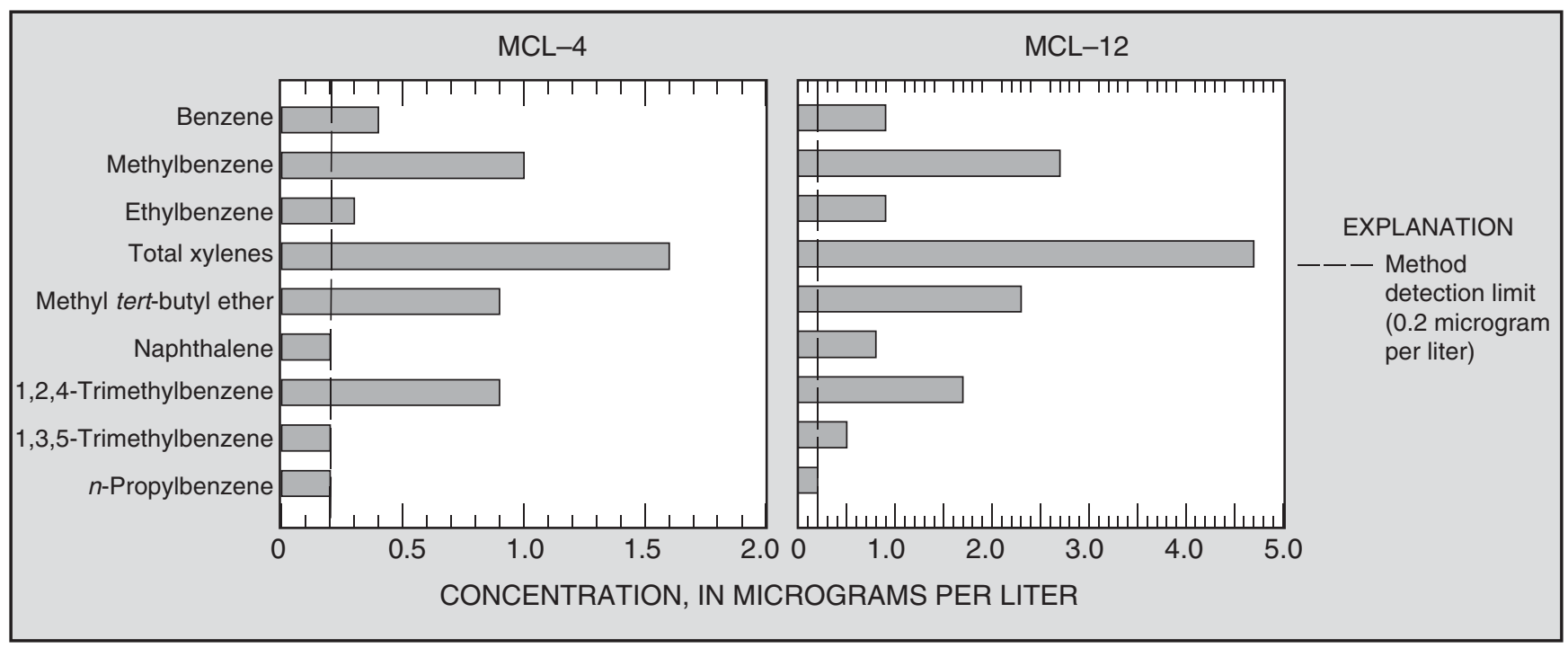

Figure 20. Volatile organic compound concentrations in lake water samples.

compounds and vinyl chloride at the Navy sites are similar to or much smaller than maximum concentrations at the NPDES sites.

\section{VOCs in Lake Water}

VOCs were detected at two of the four lake-water sampling sites (fig. 1) in Mountain Creek Lake in 1994 (Jones and others, 1997). Lake water samples from MCL -4 and MCL-12 contained small concentrations of BTEX, MTBE, and other fuel-related compounds but no chlorinated solvents (fig. 20). MCL-12 is in the NAS inlet near the NAS- 1 stormwater outfall, and MCL- 4 is southeast of MCL-12 near the middle of the lake.

Of the fuel-related compounds, only the aromatics were detected in lake water samples. Volatilization is the primary process for degradation of fuel-related VOCs in surface waters. The half-life of most aromatic hydrocarbons in lakes is on the order of 3 hours to 25 days (Howard, 1990). Half-lives of VOCs in streams vary as a function of Henry's Law constant, water velocity, wind speed, temperature, distance, and depth (Pankow and others, 1996). Concentrations of BTEX compounds in the NAS inlet (MCL-12) were 2.3 to 3 times greater than the concentrations near the middle of the lake (MCL-4). The difference in concentrations between sites could be caused by several factors including dilution and loss by volatilization.

\section{VOCs in Sediment}

Three sampling sites were selected for collection of VOCs in lake bottom sediment, Bay-7, Bay-11, and Bay-13 (fig. 1). VOCs were detected at Bay-11 (95 to $100 \mathrm{~cm}$ ) and Bay-13 (76 to $86 \mathrm{~cm}$ ) (Jones and others, 1997 , p. I-2). As many as five fuel-related compounds were detected in deeper sediment layers that were black and smelled of hydrocarbons. Chlorinated solvents, found in ground water at NWIRP, were not detected.

\section{VOCs in Fish}

Five channel catfish skin-off fillet samples analyzed for VOCs included two fish from Cottonwood Bay (one each from areas 7 and 8) and three fish from Mountain Creek Lake (two from area 10 and one from area 2) (fig. 2). Acetone, benzene, and 2-Butanone were detected at low levels $(1,000,6.9$, and $220 \mu \mathrm{g} / \mathrm{kg}$, respectively); however, sample contamination from handling in the field and at the USGS National Water Quality Laboratory is suspected (D.L. Rose, U.S. Geological Survey, oral commun., 1996). VOCs have high vapor pressures and water solubilities compared to organochlorine compounds and PAHs; therefore, VOCs generally do not accumulate in fish tissue. The Texas Department of Health (Kirk Wiles, Texas Department of Health, oral commun., 1996) concluded that VOCs in edible fish tissue are not a human health concern for the consumption of fish tissue. 


\section{Sources of VOCs}

Aircraft fuels used at both facilities include JP-4, JP-5 and AVGAS; gasoline, hydraulic fluid, and lubrication oils also are used (EnSafe/Allen \& Hoshall, 1996a, b). BTEX compounds, which are components of fuel, have been found in soil and ground-water samples at NWIRP but are not considered a major concern except in local areas (Jeffery James, EnSafe/Allen \& Hoshall, written commun., 1996). The primary compounds of concern at NWIRP are chlorinated solvents in ground water. A plume of chlorinated solvents is present in ground water beneath most of NWIRP. Large degreaser vats in buildings 1 and 6 (fig. 6) are likely sources for the chlorinated ground-water contamination on NWIRP. An off-site source west of NWIRP also probably contributes to the on-site plume. Several areas have been identified on NAS where fuel and chlorinated compounds have been found in soil and ground water (EnSafe/Allen \& Hoshall, 1996b, 1997a).

Documented petroleum, oil, and lubricant spills have occurred on NAS (EnSafe/Allen \& Hoshall, 1996b). Leaking storage tanks are the source of many of the soil and ground-water problems at the site. The NAS-1 drainage area includes six identified SWMUs (fig. 6). A 38- $\mathrm{m}^{3}$ steel storage tank located near NAS-1 is suspected of being the source of an on-site TCE ground-water plume mapped by EnSafe. Additional sources in this area include a former aircraft wash area where solvents were used and a drum storage area.

NAS-2 receives flow from stormwater and sanitary sewers in addition to surface runoff. The main fuel farm (fig. 6) for NAS is in the drainage area for NAS-2. Fuel spills historically have been routed to the fuel farm storm sewers and tanks (EnSafe/Allen \& Hoshall, 1997b). Fuel-related VOCs consistently were detected in stormwater at NAS-2, and the largest concentrations of the BTEX compounds in this study were measured at NAS -2 . The fuel farm is a likely source of the VOCs detected at NAS-2.

NAS-3 is located in an area of NAS occupied by the Texas Air National Guard. Spills and wash water from hangers and maintenance buildings historically have been washed into grated areas on the floors of the buildings, which connect to the storm sewer. The storm sewer discharges to an unlined ditch near NAS -3 .

Thus, there are potential sources of chlorinated solvents to the NWIRP stormwater sites and potential sources of fuel-related compounds and solvents to the NAS sites. Because the drainage areas to all five storm- water sites are confined to the Navy facilities, and because known sources of the VOCs detected are there, the sources are attributed to the facilities.

\section{Occurrence, Trends, and Sources of Polycyclic Aromatic Hydrocarbons}

PAHs are organic chemicals that are relatively unreactive and thus persistent in the environment. PAHs are very hydrophobic and sorb readily to sediments. Unsubstituted, or parent, compounds consist only of carbon and hydrogen (carbon-benzene rings with hydrogens attached). Substituted compounds are those PAHs in which one or more of the attached hydrogens have been replaced by alkyl groups. Hydrophobicity and resistance of PAHs to degradation increase with increasing number of rings and, within a homologous series, with increasing alkylation. A homologous series comprises compounds with the same benzene ring structure but with varying numbers of alkyl substitutions. The presence and distribution of PAHs in the environment largely is caused by incomplete combustion of coal, oil, wood, and petroleum. The largest concentrations of PAHs generally are detected in urbanized areas where the potential sources include atmospheric deposition, surface runoff, sewage effluents, industrial effluents, and spills and leakage of fossil fuels (Eganhouse and Gossett, 1991). Other sources include natural seepage of hydrocarbons, erosion of exposed shales and coal seams (Eganhouse and Gossett, 1991), and forest and prairie fires (Blumer and Youngblood, 1975).

PAHs are an environmental concern because some of these compounds are toxic or mutagenic or are known or suspected carcinogens. Sixteen PAHs are on the USEPA Priority Pollutant list (U.S. Environmental Protection Agency, 1995). Among the PAHs detected in Mountain Creek Lake are two compounds included in the first 10 of the USEPA list of the top 20 hazardous substances: benzo $(a)$ pyrene and benzo $(b)$ fluoranthene (Agency for Toxic Substances and Disease Registry, 1994).

\section{PAHs in Stormwater and Lake Water}

Only two PAHs were detected in the 30 stormwater samples collected during 1995-96 (Raines and others, 1997). Naphthalene was detected in two samples from NAS-2, and fluoranthene was detected in one sample from NAS-3. The MRL for the analytical method was either 5.0 or $10 \mu \mathrm{g} / \mathrm{L}$ depending on which 
PAH was measured. A common measure of the degree of hydrophobicity of organic compounds is the octanol/water partition coefficient $\left(\mathrm{K}_{\mathrm{ow}}\right)$. It is the measure of the distribution of a given compound in two phases, generally $n$-octanol and water, expressed as the logarithm of the concentration ratio. The $\mathrm{K}_{\mathrm{ow}}$ values for PAHs range from 3.46 for naphthalene (two rings) to 5.91 for benz $(a)$ anthracene (four rings) to 7.10 for benzo $(g h i)$ perylene (six rings) (Lucius and others, 1992; Knox and others, 1993). A $\mathrm{K}_{\mathrm{ow}}$ of 7.1 means that $10^{7.1}$ times (12.6 million) more of the compound, at equilibrium, was measured in the $n$-octanol phase than in the water phase. The hydrophobicity of these compounds causes them to partition strongly into sediment, and lack of detection of PAHs in the aqueous phase (for example, in stormwater samples) is not unusual.

In contrast to the water-sampling results, numerous PAHs were detected in suspended sediment samples in stormwater from the west and east lagoon outfalls (NWIRP-1 and NWIRP-2, respectively) and from the north and south forks of Cottonwood Creek (table 7, at end of report). PAH concentrations were larger in samples from NWIRP than in samples from Cottonwood Creek, with the largest concentrations at NWIRP-1. Concentrations of PAHs were relatively small on the more rural south fork of Cottonwood Creek. No suspended sediment samples were collected from the NAS stormwater sites.

Most PAHs were not analyzed in samples from the four lake-water sampling sites; however, naphthalene was analyzed in lake water as part of the VOC analytical schedule and was detected at site MCL-12 in the NAS inlet (Jones and others, 1997). That site is adjacent to stormwater site NAS-1, where other fuel-related VOCs were detected but not naphthalene. The two sites where PAHs were detected in stormwater, NAS-2 and NAS-3, do not drain to the lake but drain to Mountain Creek downstream from the dam.

\section{PAHs in Sediment}

PAHs were detected in all surficial (top $3 \mathrm{~cm}$ ) bottom sediment samples collected from Mountain Creek Lake (Jones and others, 1997, p. I-4, II-6). The smallest concentrations were in the upper part of the lake where all individual PAH concentrations were less than 50 $\mu \mathrm{g} / \mathrm{kg}$. Fluoranthene was the PAH with the largest concentration in all Phase I sediment samples. The fluoranthene concentration at MCL-1 in the upper lake was relatively small, $37 \mu \mathrm{g} / \mathrm{kg}$ (fig. $21 \mathrm{a}$ ). Small concentra- tions in the upper lake reflect the more rural watershed of Mountain Creek south of the Dallas area. In comparison, fluoranthene concentrations in sediment collected from Cottonwood Bay (fig. 21c) were from 1 to 3 orders of magnitude larger and an order of magnitude larger than those collected from the lake along the eastern shoreline of NAS (fig. 21d).

Phase II bottom sediment samples were analyzed for a larger number of PAH compounds and at lower method detection limits than Phase I samples (Jones and others, 1997). T-PAH concentrations in Phase II samples from east Cottonwood Bay ranged from 17,800 to $27,900 \mu \mathrm{g} / \mathrm{kg}$, except for one sample of $218,000 \mu \mathrm{g} / \mathrm{kg}$ (fig. 22). T-PAH concentrations in samples from central and west Cottonwood Bay ranged from 4,750 to $28,800 \mu \mathrm{g} / \mathrm{kg}$. All concentrations in samples from the main body of Mountain Creek Lake were less than $2,800 \mu \mathrm{g} / \mathrm{kg}$, and the median concentration of the mainlake sites was $1,210 \mu \mathrm{g} / \mathrm{kg}$. For comparison, the T-PAH concentration in surficial sediment from White Rock Lake was 2,790 $\mu \mathrm{g} / \mathrm{kg}$ (Van Metre and others, 2000). A streambed sediment sample collected from Cottonwood Creek where Eighth Street crosses it west of Cottonwood Bay (M2.23) had a T-PAH concentration of $20,600 \mu \mathrm{g} / \mathrm{kg}$, reflecting urban land use and possibly additional enrichment from proximity to Eighth Street. This concentration is comparable to concentrations in the western and central parts of Cottonwood Bay.

The largest concentrations of the two PAHs ranked in the first 10 of the USEPA list of top 20 hazardous substances (Agency for Toxic Substances and Disease Registry, 1994), benzo( $a$ )pyrene and benzo $(b)$ fluoranthene, were in bottom sediments from east Cottonwood Bay (fig. 23). The median concentration of benzo $(a)$ pyrene in the 0 - to 3-cm interval from Phase II samples in east Cottonwood Bay was 1,570 $\mu \mathrm{g} / \mathrm{kg}$, and the maximum concentration was 11,100 $\mu \mathrm{g} / \mathrm{kg}$; the median concentration in main-lake sites was $97.3 \mu \mathrm{g} / \mathrm{kg}$. Benzo(a)pyrene was not detected (less than $150 \mu \mathrm{g} / \mathrm{kg}$ ) at MCL-1 in the upper part of the lake during Phase I. The median benzo $(b)$ fluoranthene concentration in east Cottonwood Bay was $1,850 \mu \mathrm{g} / \mathrm{kg}$, and the maximum was $13,000 \mu \mathrm{g} / \mathrm{kg}$; the main-lake median was $98.2 \mu \mathrm{g} / \mathrm{kg}$.

Concentrations of PAHs in the NAS inlet generally were larger than in the main lake but smaller than in Cottonwood Bay (figs. 21, 22). The median benzo $(a)$ pyrene concentration in Phase II samples from the NAS inlet was $411 \mu \mathrm{g} / \mathrm{kg}$ compared to a median of $98.2 \mu \mathrm{g} / \mathrm{kg}$ in samples farther from shore in the main 


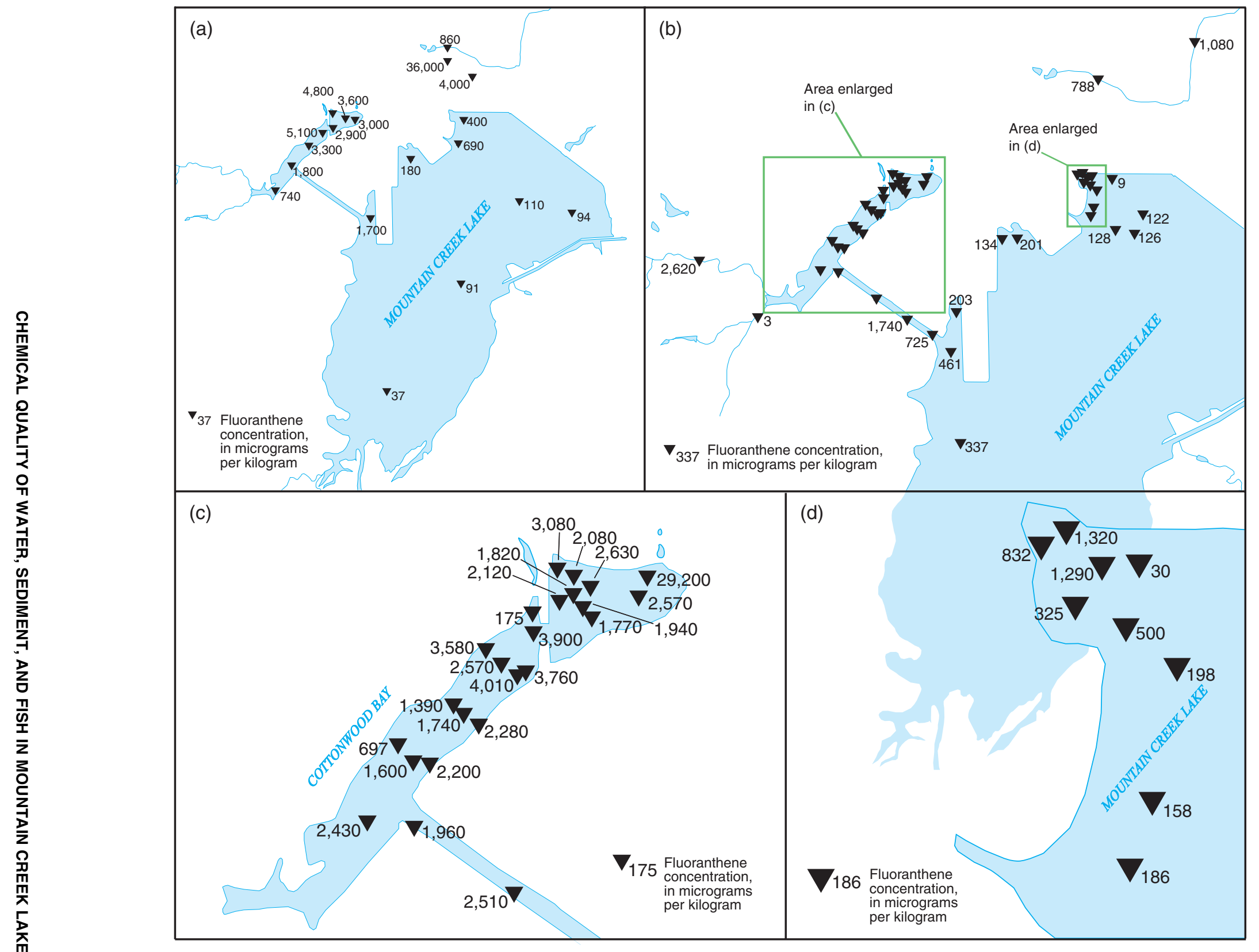

Figure 21. Fluoranthene concentrations in top 3 centimeters of lake bottom sediments from (a) Phase I sampling; (b) Phase II sampling; 


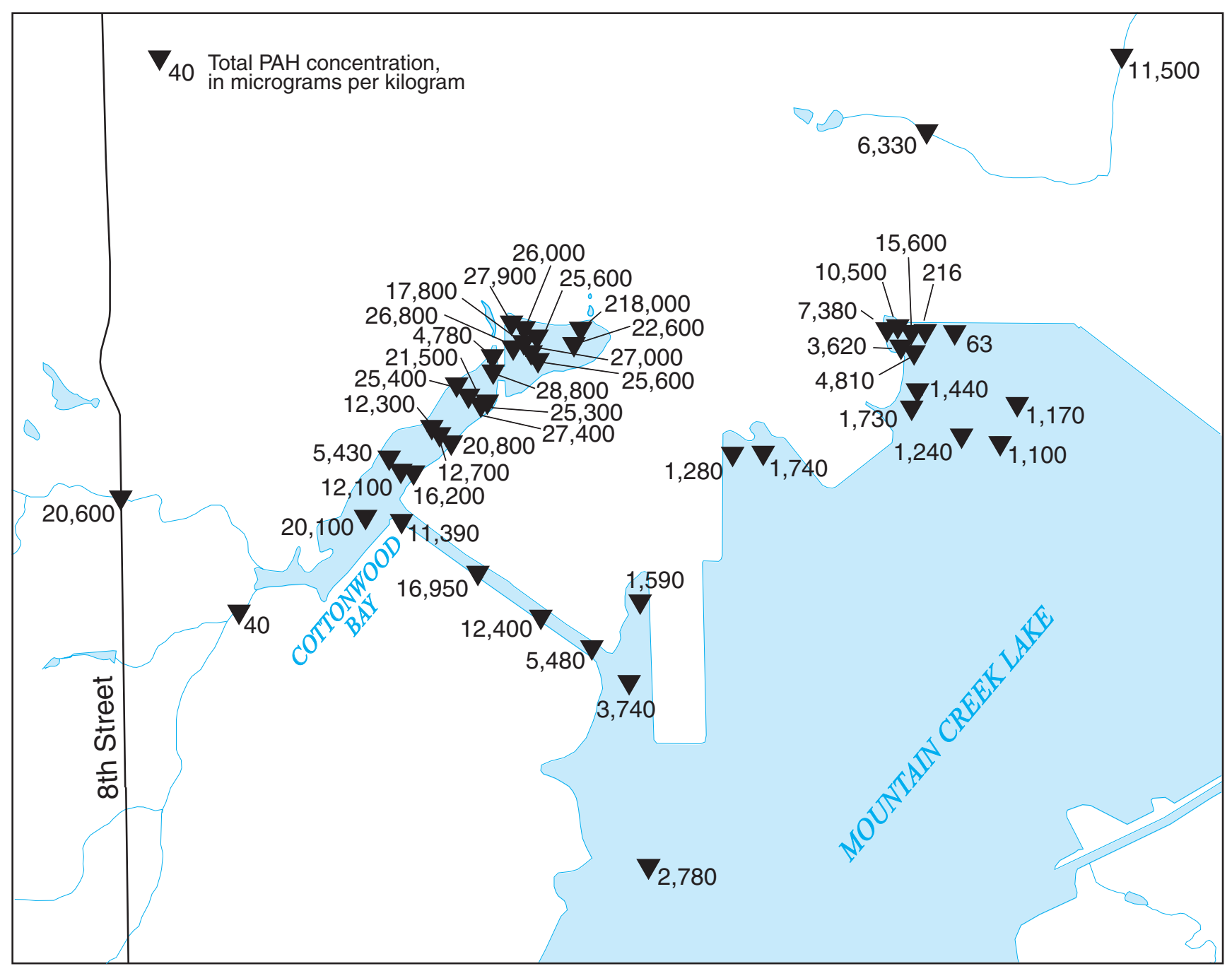

Figure 22. Total PAH concentrations in top 3 centimeters of surficial sediment from Phase II sampling.

lake (fig. 23). T-PAH concentrations in the NAS inlet ranged from 216 to $15,600 \mu \mathrm{g} / \mathrm{kg}$ compared to T-PAH concentrations of 63 to $3,740 \mu \mathrm{g} / \mathrm{kg}$ in main-lake samples (fig. 22).

PAHs were measured in three Phase I and two Phase II sediment samples from small streams draining the northeastern part of NAS to Mountain Creek downstream from the dam (figs. 1,2). One of those samples, from a stream known locally as the TANG Canal (site NAS-3), had large PAH concentrations with a T-PAH of $159,000 \mu \mathrm{g} / \mathrm{kg}$. Moderately elevated T-PAH concentrations compared to the main-lake sites were detected in sediment samples from two nearby streambeds: NAS-2 and NAS -4 had detections of 21,400 and $4,730 \mu \mathrm{g} / \mathrm{kg}$, respectively. T-PAH concentrations in two samples col- lected farther downstream at Phase II sites M2.46 and M2.47 also were moderately elevated at 6,330 and $11,500 \mu \mathrm{g} / \mathrm{kg}$, respectively (fig. 22), similar to concentrations at the Cottonwood Creek urban reference site and the NAS inlet sites.

T-PAH concentrations in the MCL -4 gravity core, at the center of Mountain Creek Lake, increased from less than $100 \mu \mathrm{g} / \mathrm{kg}$ at the bottom of the core to $910 \mu \mathrm{g} / \mathrm{kg}$ in the most recently deposited sediment (fig. 24). Similar temporal patterns occur in sediment cores from White Rock Lake and from Lake Anne in Reston, Va. (Van Metre and others, 2000). These trends probably result from increased population growth and automobile use in the watersheds of these reservoirs. In contrast to gradually increasing trends in the main 


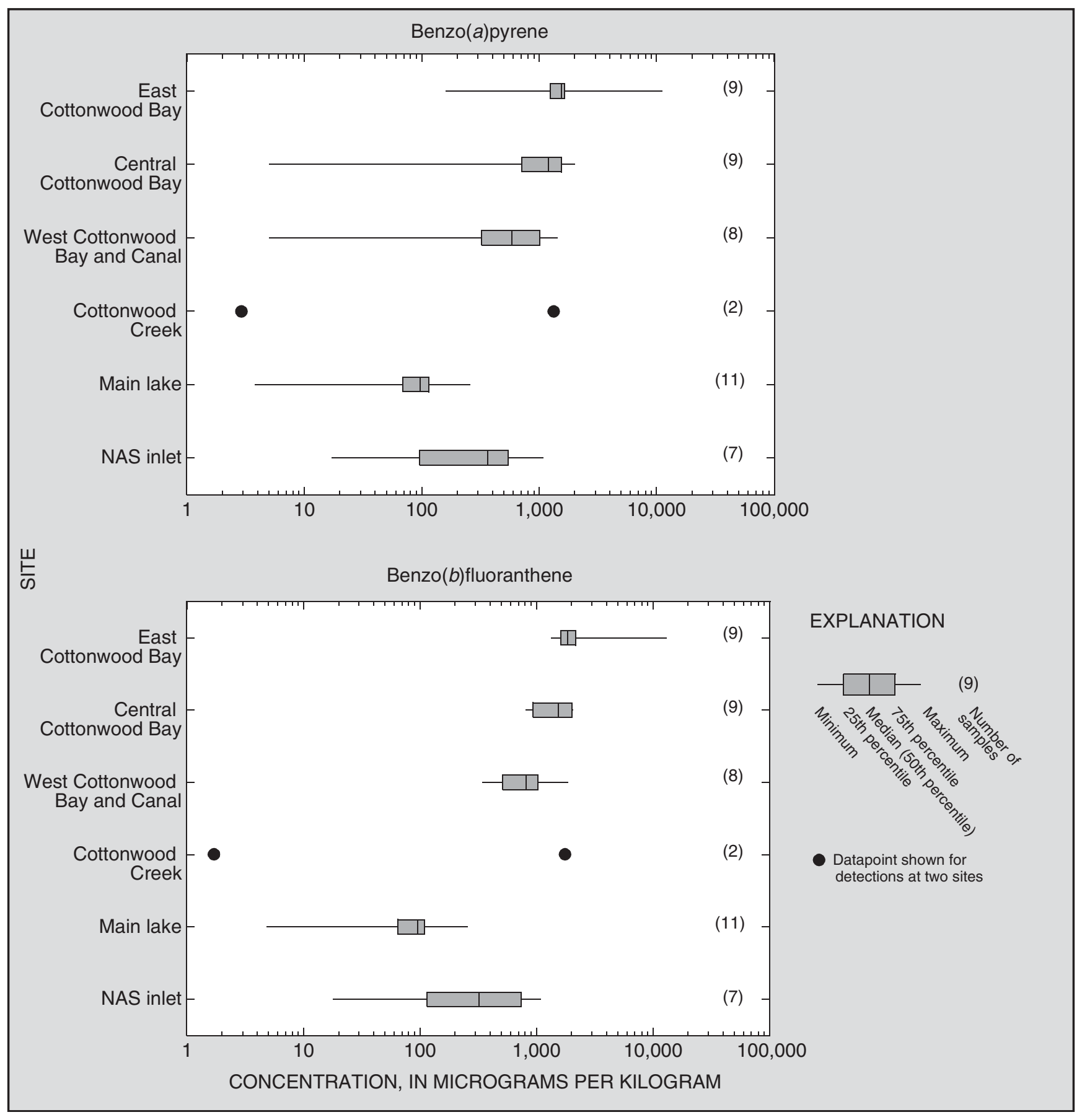

Figure 23. Distribution of benzo(a)pyrene and benzo $(b)$ fluoranthene concentrations in top 3 centimeters of surficial sediment.

part of the lake, T-PAH trends in Cottonwood Bay are decreasing from larger historical levels. The largest T-PAH concentrations in the MCL-7 core (central bay) were detected in sediment deposited in the 1950s. These concentrations are about 60 percent larger than concen- trations in sediment deposited during the same time period in the Bay-13 core (east bay) (fig. 24). T-PAH concentrations at Bay-13 increased from slightly less than $6,000 \mu \mathrm{g} / \mathrm{kg}$ in sediments deposited in the $1930 \mathrm{~s}$ to $43,100 \mu \mathrm{g} / \mathrm{kg}$ in sediments deposited in about 


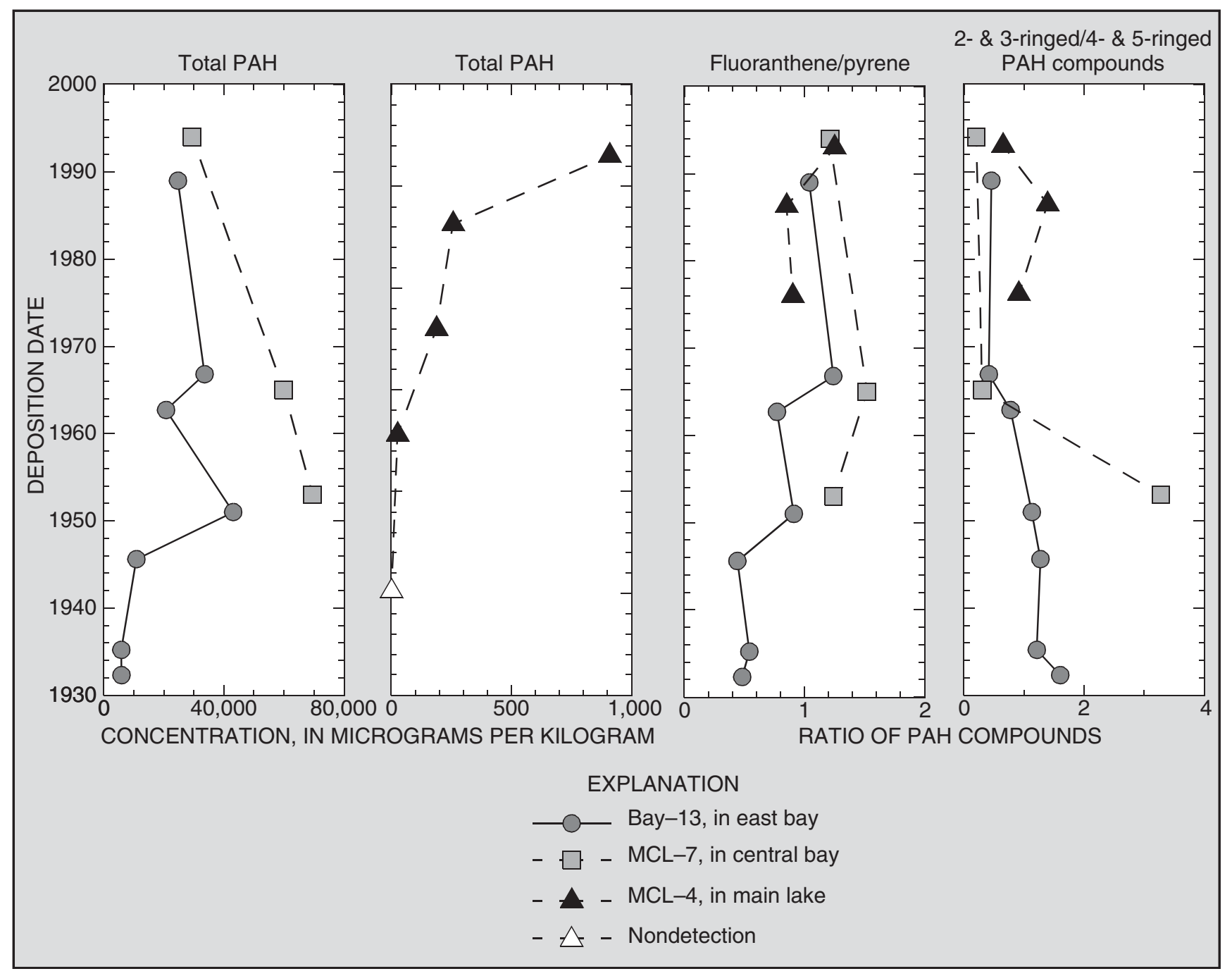

Figure 24. Trends in PAH concentrations in Bay-13, MCL-7, and MCL-4 cores.

1950. Concentrations then decreased to $24,700 \mu \mathrm{g} / \mathrm{kg}$ in recently deposited sediments, similar to those in recently deposited sediments at MCL-7.

T-PAH concentrations in sediment samples collected during Phase II from core M2.40 in the NAS inlet ranged from 527 to $5,500 \mu \mathrm{g} / \mathrm{kg}$ (fig. 25). The smallest concentration was in sediments at the bottom of the core; these sediments were deposited in about 1940. Sediments deposited in the 1940s and 1950s showed increasing amounts of T-PAH, culminating in sediment deposited in the mid-1950s (50- to 55-cm interval) with $5,500 \mu \mathrm{g} / \mathrm{kg}$, about 3 times the T-PAH concentration as in sediment samples above and below that interval. Concentrations then decreased and remained somewhat constant at 1,500 to $2,000 \mu \mathrm{g} / \mathrm{kg}$ to the top of the core.
The increase in T-PAH concentrations from the 1940s into the 1950s is coincident with increasing activities on NAS and probably indicates an effect of those activities on the quality of water and sediment discharging into the inlet. Concentrations at the NAS inlet, however, were small compared to those in Cottonwood Bay and the north fork of Cottonwood Creek.

\section{PAHs in Fish}

Five channel catfish skin-off fillet samples analyzed for PAHs (Jones and others, 1997, p. II-32) included two fish from Cottonwood Bay (one each from areas 7 and 8) and three fish from Mountain Creek Lake (two from area 10 and one from area 2) (fig. 2). Only five samples were analyzed because, unlike 


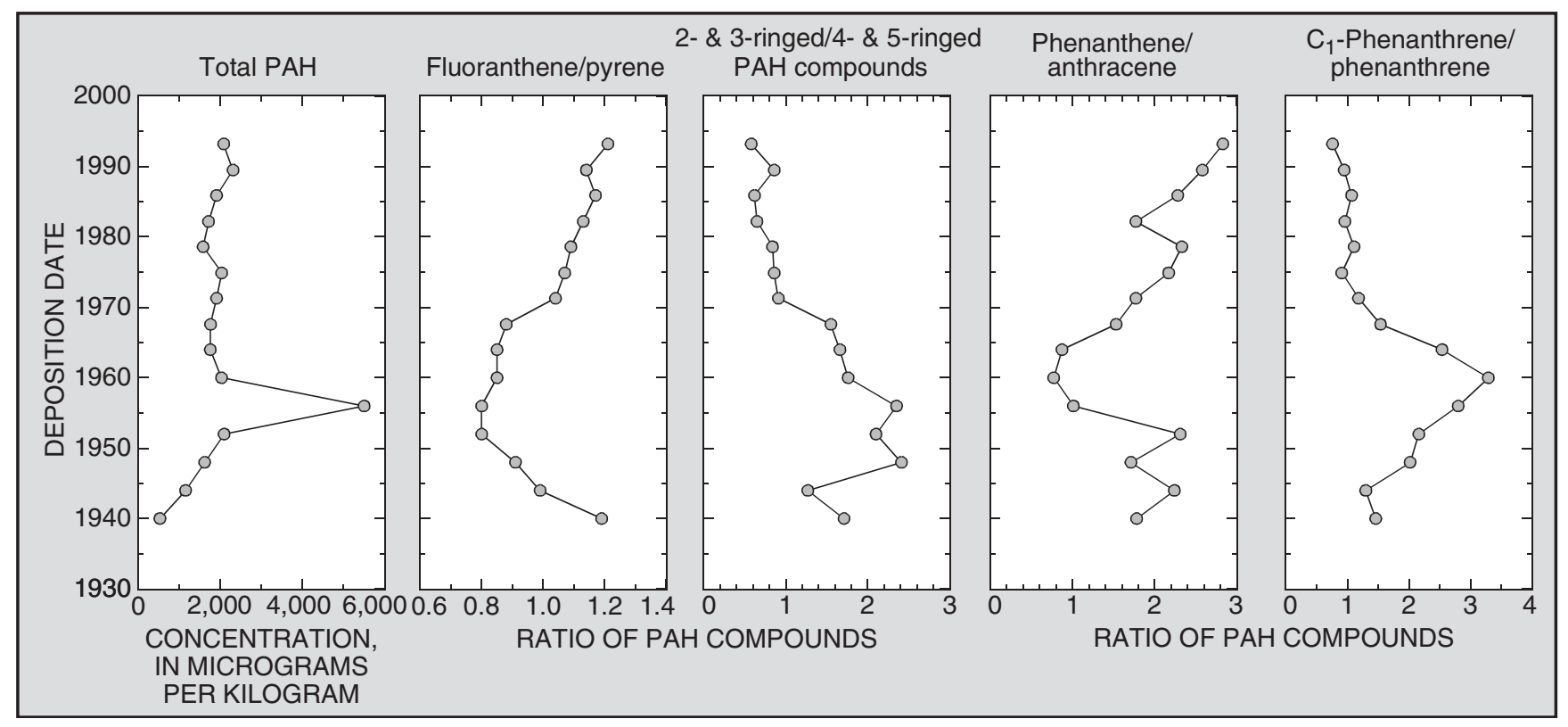

Figure 25. Trends in PAH concentrations in M2.40 core in the NAS inlet.

organochlorine pesticides and PCBs, PAHs that are taken up across gill membranes or ingested are metabolized by the fish's mixed-oxidase system to form metabolites that are excreted (Eisler, 1987). Of the 16 PAHs on the USEPA Priority Pollutant list (U.S. Environmental Protection Agency, 1995), only fluoranthene and pyrene were detected in the channel catfish fillets. Fluoranthene concentrations ranged from one nondetection to $39 \mu \mathrm{g} / \mathrm{kg}$, and pyrene concentrations ranged from two nondetections to $32 \mu \mathrm{g} / \mathrm{kg}$. The Texas Department of Health (Kirk Wiles, Texas Department of Health, oral commun., 1996) concluded that PAHs in edible fish tissues are not a human health concern for the consumption of fish tissues.

\section{Sources of PAHs}

The sources of PAHs in sediment from Mountain Creek Lake, in suspended sediment, and in sediment from nearby streams are discussed in two sections. The chemical origin of PAHs (pyrogenic versus uncombusted fuel sources) on the basis of relative abundance of selected PAHs is presented first. An evaluation of physical locations (spatial sources) where PAHs might have originated on the Navy facilities or urban areas around the lake is presented second.

\section{Pyrogenic Versus Uncombusted Fuel Sources}

The relative abundance of selected PAHs can indicate whether they are derived from pyrogenic (combustion related) or uncombusted fuel sources. Crude oil and refined petroleum contain predominantly 2-and 3-ringed PAH compounds, whereas combustion results in predominantly 4- and 5-ringed compounds (Hites and others, 1981; Eganhouse and Gossett, 1991). PAHs produced by combustion are characterized by the predominance of fluoranthene over pyrene (Eganhouse and Gossett, 1991) or phenanthrene over anthracene (Heit, 1985), and they tend to contain 4-ringed compounds (fluoranthene and pyrene and $\mathrm{C}_{1-3}$ alkylated homologues) as a large proportion of the T-PAH (Sporst $\varnothing 1$ and others, 1983). A typical characteristic of a petroleum source is enrichment of the alkylated homologues relative to the parent compounds. For example, samples of wastewater effluent from the Los Angeles County Sanitation District in California, which receives petrochemical waste in its influent, had a fluoranthene/ pyrene ratio of about 0.5 indicating uncombusted fuel sources (Eganhouse and Gossett, 1991). In contrast, sediments from Cayuga Lake in New York, which receives regional atmospheric deposition from pyrogenic sources (for example power plants), had a fluoranthene/pyrene ratio of 12 or more (Heit, 1985). 
PAHs in surficial sediment in Mountain Creek Lake near NWIRP (sites M2.1 through M2.22), in and near the canal (sites M2.24 through M2.30), and offshore from the NAS inlet (sites M2.31 through M2.45) appear to be predominantly from pyrogenic sources rather than uncombusted fuel sources (fig. 26; table 8, at end of report). The pyrogenic source is indicated by a fluoranthene/pyrene ratio greater than 1.0; enrichment of 4- and 5-ringed compounds relative to 2- and 3ringed; predominance of parent phenanthrene over the singly-alkylated homologue; and large percentage of T-PAH composed of the 3-ringed series and their $\mathrm{C}_{1-3}$ alkylated homologues. The composition of the PAHs found in the sediment offshore of NAS differs significantly from those near NWIRP (t-test p-value less than .001). Although samples from both locations are predominantly pyrogenic in origin, NAS offshore samples are relatively more fuel-related (table 8 ). VOCs in stormwater samples were predominantly fuel-related from NAS and solvent-related from NWIRP, which indicates relatively more fuel-related releases to the NAS inlet than to Cottonwood Bay.

The two diagnostic ratios that can be computed for east lagoon surficial sediment on NWIRP have a relatively strong pyrogenic signal: The fluoranthene/ pyrene ratio is 1.33 or greater for five of the six sludge samples, and the phenanthrene/anthracene ratio is 6.8 or greater for three of the six sludge samples. The suspended sediment sample from the east lagoon has a similarly strong pyrogenic signal with a fluoranthene/ pyrene ratio of 1.27 and a phenanthrene/anthracene ratio of 6.9 .

Bottom and suspended sediments from the west lagoon also have pyrogenic signals. The median fluoranthene/pyrene ratio in five west lagoon surficial sediment samples is 1.24 , and the median phenanthrene/ anthracene ratio 4.75 (fig. 26). The fluoranthene/pyrene ratios in the two suspended sediment samples are 1.15 and 1.19, and the phenanthrene/anthracene ratios are 6.6 and 8.3 , all indicating pyrogenic sources.

At the southwestern end of Cottonwood Bay the PAH compositions reflect the probable contribution of sediment from Cottonwood Creek. The north fork of Cottonwood Creek has a relatively large phenanthrene/ anthracene ratio of 6.36 in bottom sediment (site M2.23, fig. 26) and 9.3 and 11 in suspended sediments, indicating pyrogenic origin. Site M2.20 (west bay) near the canal has a relatively large phenanthrene/anthracene ratio of 6.17. Moving down the canal toward the main body of the lake, T-PAH concentrations decrease to a concentration of $3,000 \mu \mathrm{g} / \mathrm{kg}$ in sediment at site M2.30 in the main lake. As T-PAH concentrations decrease down the canal, phenanthrene/anthracene ratios decrease and $\mathrm{C}_{1}$-phenanthrene/phenanthrene ratios increase, indicating increased contribution from uncombusted fuel sources. Because main-lake reference site PAHs tend to be from uncombusted fuel sources, this shift from pyrogenic to fuel-related sources could be caused by smaller inputs of pyrogenic PAHs rather than from greater inputs of fuels.

Large concentrations of PAHs were detected in samples collected during Phase I in a small streambed in the northeastern part of NAS (site NAS-3). The laboratory analysis of Phase I samples did not include the full suite of 64 PAH compounds that the Phase II analyses included, thus the computed T-PAH concentration from the laboratory analysis of $159,000 \mu \mathrm{g} / \mathrm{kg}$ underestimates the actual T-PAH concentration. Source indicators at NAS-3 that are based on PAH composition are ambiguous: Although the sample has a fairly large fluoranthene/pyrene ratio of 1.38 , indicating a pyrogenic origin, the very small phenanthrene/anthracene ratio of 2.08 indicates a fuel origin. Several SWMUs in the immediate vicinity could be sources of PAHs, including floor drains conveying motor and hydraulic oil from spills, oil-water separators, and two underground storage tanks containing waste petroleum (EnSafe/Allen \& Hoshall, 1995).

Temporal trends in PAH source indicators also occur. The fluoranthene/pyrene ratio in the Bay-13 core increased from 0.5 in sediments deposited in the 1930s and 1940s to more than 1.0 in sediments deposited from the late 1960s to the present (fig. 24). The 2- and 3ringed/4- and 5-ringed ratio decreased from about 1.6 in the lower part of the core to less than 0.5 in recently deposited sediments. At Bay-13, both of these indicators point to a change from uncombusted fuel sources to pyrogenic sources.

Four different indicators suggest that PAHs in the M2.40 core in the NAS inlet shifted from uncombusted fuel sources in the 1940s toward more pyrogenic, typically urban sources in the 1960s and later (fig. 25). The ratio of fluoranthene to pyrene, less than 1.0 in sediments deposited from the 1940s (except for 1.2 in 1940) through the $1960 \mathrm{~s}$ at M2.40, increases to greater than 1.0 in sediments deposited from about 1970 to the present. Similarly, the 2- and 3-ringed/4- and 5-ringed ratio is greater than 1.0 in sediments deposited from the 1940s through the 1960s and less than 1.0 in sediments deposited after 1970. Relative amounts of phenanthrene 


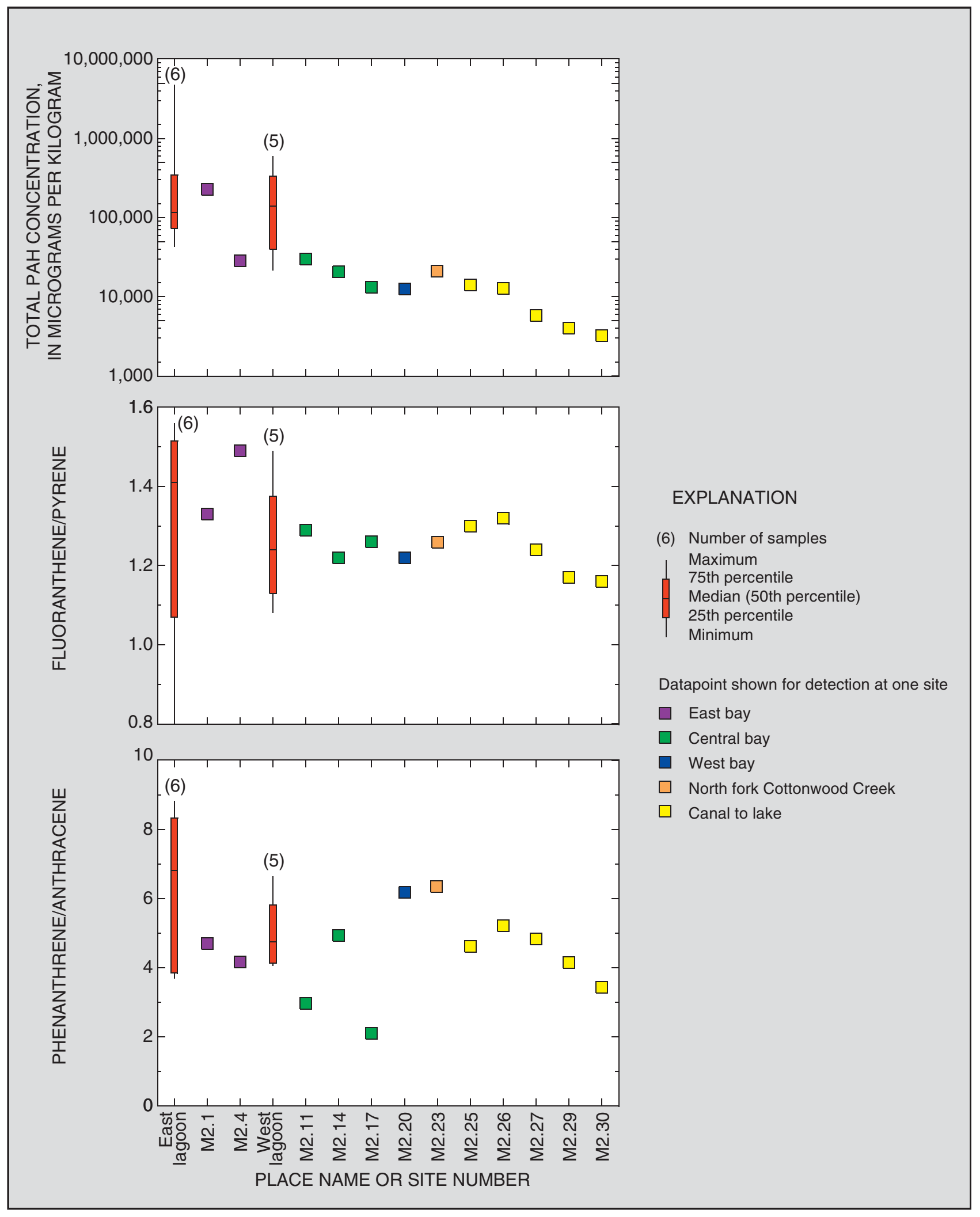

Figure 26. Longitudinal variation in total PAH and source indicator ratios for surficial sediment samples. 
and anthracene also are indicative of a shift from fuel sources to pyrogenic sources. The phenanthrene/ anthracene ratio, about 2.0 in sediments deposited in the $1940 \mathrm{~s}$, decreases to less than 1.0 in sediments deposited in the mid-1950s to the mid-1960s, then increases in sediments deposited from the mid-1960s until the present, reaching its 1994 value of just less than 3.0. The smallest ratios of phenanthrene/anthracene are in petroleum products. Urban runoff, which usually contains pyrogenic PAHs with some petroleum product, generally has a phenanthrene/anthracene ratio of 3 to 5 , and ratios greater than 10 are found at remote sites where the source of PAHs is atmospheric deposition (Gschwend and Hites, 1981). Finally, enrichment in the alkylated homologue relative to the parent PAH in sediments deposited at the site from the 1940s to the 1960s, indicative of a fossil-fuel origin, is illustrated by the $\mathrm{C}_{1^{-}}$ phenanthrene/phenanthrene ratio in figure 25 . This ratio peaks at 3.3 for sediments deposited in about 1960 and decreases to about 1.0 for sediments deposited in the mid-1970s. A ratio of 0.76, indicative of a pyrogenic origin, was computed for the most recently deposited sediments.

\section{Spatial Sources of PAHs}

T-PAH concentrations in two suspended sediment samples collected in 1997 from the north fork of Cottonwood Creek were 3,000 and 1,000 $\mu \mathrm{g} / \mathrm{kg}$, about onetenth the concentration in the streambed sample from the site. The difference could indicate enrichment of the bottom sediment from local runoff from the bridge and road. The T-PAH concentration in a suspended sediment sample from the south fork of Cottonwood Creek was $890 \mu \mathrm{g} / \mathrm{kg}$, smaller than the north fork concentrations but about 10 times greater than the very small concentration in the streambed sample from the site. These concentrations indicate that some PAHs are transported to Cottonwood Bay by the north and south forks of Cottonwood Creek.

Analyses were done to indicate whether the east and west lagoons were sources of PAHs. PAHs were measured in the sediment samples collected in the east and west lagoons by EnSafe/Allen \& Hoshall (1996a); however, analyses of lagoon sediments included only 16 of the 64 compounds that were analyzed in the USGS Phase II Mountain Creek Lake samples. The EnSafe/ Allen \& Hoshall (1996a) analyses included primarily parent PAH compounds and excluded most of the alkylated homologues. The 16 compounds account for
17 to 80 percent of the T-PAH in USGS Phase II samples; this wide range is caused by variations in the relative concentrations of various PAH compounds. T-PAH concentrations for the lagoon sediment were estimated by linear regression. The regression equation was developed using Phase II results in Cottonwood Bay by relating measured T-PAH to the sum of concentrations of 10 of the compounds analyzed by EnSafe: pyrene, 9H-fluorene, chrysene, acenaphthalene, fluoranthene, benzo $(a)$ anthracene, benzo $(b)$ fluoranthene, benzo $(k)$ fluoranthene, benzo $(a)$ pyrene, and benzo $(g h i)$ perylene. The coefficient of regression $\left(\mathrm{r}^{2}\right)$ was 0.999 , the regression was significant $(\mathrm{p}$-value $=$ .001 ), and the standard error of the estimate (SE) was $1,420 \mu \mathrm{g} / \mathrm{kg}$. The regression equation was used with data from EnSafe/Allen \& Hoshall (1996a) to estimate T-PAH in the lagoon sediments (table 9, at end of report). Estimated T-PAH concentrations in the upper $60 \mathrm{~cm}$ of sediments from the east lagoon range from 88,100 to $4,720,000 \mu \mathrm{g} / \mathrm{kg}$, and estimated concentrations in the upper $60 \mathrm{~cm}$ of sediments from the west lagoon range from 21,400 to $540,000 \mu \mathrm{g} / \mathrm{kg}$.

The T-PAH concentration in a stormwater suspended sediment sample collected at the east lagoon outfall in 1997 was $5,500 \mu \mathrm{g} / \mathrm{kg}$, smaller than the concentrations in lagoon bottom sediment or in surficial bottom sediment in Cottonwood Bay (fig. 26). T-PAH concentrations in two suspended sediment samples from the west lagoon outfall were 26,000 and $22,000 \mu \mathrm{g} / \mathrm{kg}$, comparable to average surficial sediment concentrations in central and east Cottonwood Bay. The mixture of individual PAH compounds and the magnitude of concentrations detected in the suspended sediment samples from the west lagoon (fig. 27) are similar to PAHs in west lagoon and central bay bottom sediments.

Sources of PAHs in east and central Cottonwood Bay are most likely the east and west lagoons. The large concentration of PAHs in the east lagoon and the proximity of the outfall from the lagoon to site M2.1, where the T-PAH concentration was $218,000 \mu \mathrm{g} / \mathrm{kg}$ (fig. 26) indicate that the east lagoon is the most likely source of the PAH contamination in the eastern end of the bay. At site M2.4, about $260 \mathrm{~m}$ from the outfall, the T-PAH concentration was $27,000 \mu \mathrm{g} / \mathrm{kg}$ (fig. 26). The relatively small PAH concentration in the east lagoon outfall suspended sediment sample suggests current transport of the more highly contaminated sediments in the east lagoon is not occurring. The T-PAH concentration was slightly larger at site M2.11, which is near the outfall 


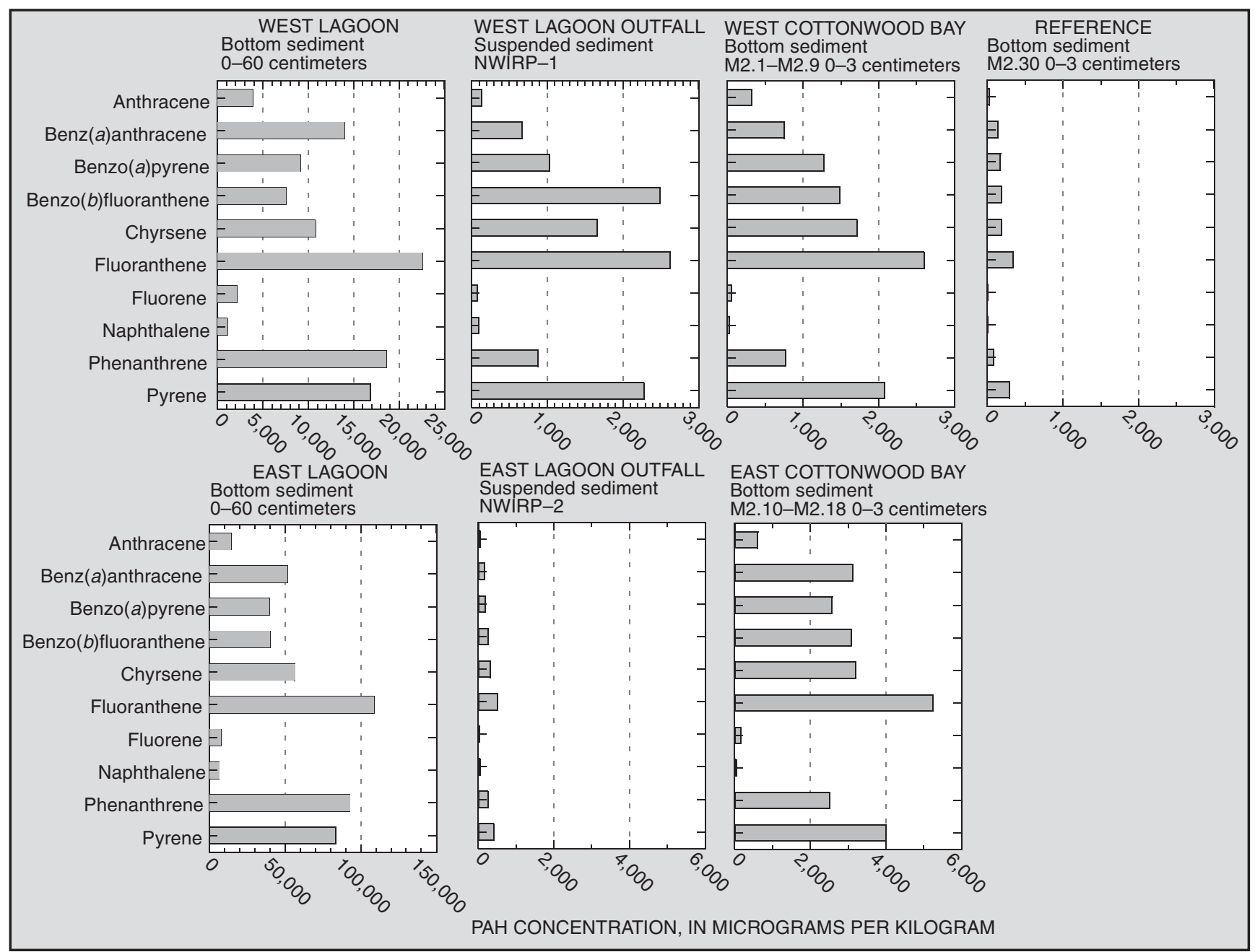

Figure 27. Comparison of lake-bottom sediment and suspended sediment PAH concentrations in the east and west lagoons and Cottonwood Bay.

from the west lagoon. T-PAH concentrations decrease along the length of Cottonwood Bay to the canal. At the canal, T-PAH concentrations again increase, possibly because of the contribution of sediments from urban sources in the Cottonwood Creek watershed. A relatively large concentration of T-PAH was found in a streambed sediment sample from the urbanized north fork of Cottonwood Creek (site M2.23, 20,600 $\mu \mathrm{g} / \mathrm{kg}$ ) and a very small concentration of T-PAH was found in the less-urban south fork (site M2.48, $40 \mu \mathrm{g} / \mathrm{kg}$ ). The north fork of Cottonwood Creek drains a residential and commercial area of Grand Prairie, Tex.; additionally, the sampling site is beneath a four-lane bridge.

Several SWMUs on NAS along the canal might be sources of petroleum-derived PAHs. SWMU 81 (fig. 6) is a storm sewer that discharges petroleumcontaminated wastewater runoff, spent solvents, waste petroleum, and waste oil and sludge; SWMU 20 and 29 are underground storage tanks containing waste petroleum; SWMU 14 and 6 are firefighter training areas contaminated with jet fuel, aviation gasoline, and waste petroleum; and SWMU 1 is a landfill contaminated with waste oil and sludge (EnSafe/Allen \& Hoshall, 1995). Decreasing T-PAH concentrations along the canal, however, indicate that any contributions from these SWMUs must be relatively small.

PAHs at the NAS inlet are most likely the result of the presence of a fuel farm and other fuel-related SWMUs (EnSafe/Allen \& Hoshall, 1996b) combined with runoff from roads and parking areas. Sediment 
from several SWMUs near the lake contained PAHs. For example samples from Group 12, a 7.6- $\mathrm{m}^{3}$ tanker truck, contained benzo $(a)$ anthracene, benzo( $z$ )pyrene, benzo $(b)$ fluoranthene, benzo $(k)$ fluoranthene, chrysene, fluoranthene, indeno(1,2,3-cd)pyrene, phenanthrene, and pyrene; samples from SWMU 2P, a former paint disposal area, contained fluoranthene, pyrene, and naphthalene; and samples from Group 11, SWMU 26P, an underground storage tank, contained anthracene, benzo $(a)$ anthracene, chrysene, fluoranthene, phenanthrene, and pyrene. These SWMUs could be sources of petroleum-derived PAHs along the NAS inlet shoreline.

\section{Occurrence, Trends, and Sources of Organochlorine Pesticides}

Organochlorine pesticides include well-known compounds such as DDT, chlordane, and dieldrin, all of which were detected in Mountain Creek Lake sediment and fish. DDT was first synthesized in 1874 and was used as an insecticide starting in 1939 (U.S. Environmental Protection Agency, 1983). Use of DDT peaked in the United States in the early 1960s (Rapaport and others, 1985) and was banned nationwide in 1972 (Smith and others, 1988). DDT is not long-lived in the natural environment, and it readily breaks down into two metabolites, DDD and DDE, both of which are resistant to further breakdown.

The insecticidal properties of chlordane were first identified in 1945 (Smith and others, 1988); chlordane was first produced commercially in the United States in 1947 (U.S. Environmental Protection Agency, 1983).

Agricultural use of chlordane principally was on corn, and nationwide agricultural use in 1971 was an estimated $857,000 \mathrm{~kg}$ of active ingredient (U.S. Department of Agriculture, 1974). Limited use of chlordane, following USEPA restrictions in 1983, continued as a termiticide and for control of fire ants until virtually all uses were banned in 1988 because of environmental concerns. After 1988, the only permitted uses of chlordane were for fire ant control in power transformers and for the use of existing stocks in the possession of homeowners (U.S. Environmental Protection Agency, 1990). Home and garden use of chlordane was an estimated $524,000 \mathrm{~kg}$ in 1990 (Whitmore and others, 1992), which indicates relatively large recent use in some urban areas.

Dieldrin is an insecticide and also a metabolite of the insecticide aldrin. Aldrin and dieldrin were synthesized in the laboratory in 1948 and registered for commercial production in 1951 (U.S. Environmental
Protection Agency, 1983). Aldrin and dieldrin were used to control pests on corn until farm uses were banned in 1974. Subsurface ground insertion for termite control, dipping of non-food roots and tops, and mothproofing by manufacturing processes in closed systems were allowed to continue (U.S. Environmental Protection Agency, 1983). Aldrin and dieldrin use was banned in all products in May 1987 (U.S. Environmental Protection Agency, 1990). Unlike chlordane, no home and garden use of aldrin or dieldrin was reported in 1990 (Whitmore and others, 1992).

\section{Organochlorine Pesticides in Stormwater and Lake Water}

Organochlorine pesticides were not detected in any of the 30 stormwater samples (Raines and others, 1997) or the four lake water samples (Jones and others, 1997). The MRL of the analytical method used for stormwater was $0.1 \mu \mathrm{g} / \mathrm{L}$ for DDT and its metabolites, $0.5 \mu \mathrm{g} / \mathrm{L}$ for chlordane, and $0.05 \mu \mathrm{g} / \mathrm{L}$ for dieldrin. The MRL of the analytical method used for lake water was $0.006 \mu \mathrm{g} / \mathrm{L}$ for DDE, $0.002 \mu \mathrm{g} / \mathrm{L}$ for chlordane, and $0.001 \mu \mathrm{g} / \mathrm{L}$ for dieldrin. The ranges of $\log \mathrm{K}_{\mathrm{ow}}$ values reported for DDT, chlordane, and dieldrin are 3.98 to 6.19, 2.78 to 6.00, and 3.54 to 5.16, respectively (Lucius and others, 1992). The $\mathrm{K}_{\mathrm{ow}}$ values indicate that these compounds are hydrophobic and will partition strongly into sediment. Concentrations of DDT, chlordane, and dieldrin in water therefore are expected to be small.

Although organochlorine pesticides were not detected in stormwater samples, several were detected in suspended sediment samples from the urban reference site on Cottonwood Creek (table 10, at end of report). Chlordane had the largest concentrations at 13 and $11 \mu \mathrm{g} / \mathrm{kg}$ in the two samples from the north fork of Cottonwood Creek. Chlordane was not detected in any of the other four samples; however, the MRLs for chlordane in those samples were relatively large because of the small sample masses analyzed. Dieldrin, $p, p^{\prime}$-DDE, and $p, p^{\prime}$-DDT also were detected in suspended sediment samples from the north fork of Cottonwood Creek. Although organochlorine pesticides are not detected frequently in urban stormwater (Baldys and others, 1998), they are detected frequently in reservoir bottom sediments from urban areas (Van Metre and Callender, 1997; Van Metre, Callender, and Fuller, 1997). 


\section{Organochlorine Pesticides in Sediment}

The same group of organochlorine pesticides detected in Cottonwood Creek suspended sedimentchlordane, dieldrin, $p, p^{\prime}$-DDT, and $p, p^{\prime}$-DDE-also was detected in Mountain Creek Lake bottom sediment (Jones and others, 1997, p. I-14-II-18). Concentrations in the surficial (top $3 \mathrm{~cm}$ ) sediment generally were small throughout the main body of the lake and Cottonwood Bay and larger in the NAS inlet. For example, total DDT concentrations in Phase I samples from the main lake and Cottonwood Bay ranged from 0.4 to $3.1 \mu \mathrm{g} / \mathrm{kg}$ compared to 0.4 to $18 \mu \mathrm{g} / \mathrm{kg}$ in the NAS inlet. The distribution of pesticides was similar-small concentrations in Cottonwood Bay and some relatively larger concentrations in the NAS inlet-for total DDT, chlordane, and dieldrin. Two larger concentrations of chlordane in Cottonwood Bay, $16.0 \mu \mathrm{g} / \mathrm{kg}$ in MCL-6 and $10.5 \mu \mathrm{g} / \mathrm{kg}$ in MCL-7, were similar to concentrations in suspended sediments from the north fork of Cottonwood Creek.

Phase II sediment analyses of organochlorine pesticides were limited to the seven sites in the NAS inlet. Samples from the inlet had a median total DDT concentration of $3.7 \mu \mathrm{g} / \mathrm{kg}$. Site M2.39 had the largest total DDT concentration, $18.0 \mu \mathrm{g} / \mathrm{kg}$. Concentrations of $p, p^{\prime}$-DDE in the inlet ranged from 0.2 to $6.4 \mu \mathrm{g} / \mathrm{kg}$ with a median of $1.7 \mu \mathrm{g} / \mathrm{kg}$; and $p, p^{\prime}$-DDD ranged from 0.15 to $11 \mu \mathrm{g} / \mathrm{kg}$ with a median of $1.8 \mu \mathrm{g} / \mathrm{kg}$. Six of seven samples had detectable concentrations of $p, p^{\prime}$-DDT with a range of less than 0.1 to $3.5 \mu \mathrm{g} / \mathrm{kg}$ and a median of $0.48 \mu \mathrm{g} / \mathrm{kg}$. These concentrations are similar to concentrations of organochlorine pesticides measured in other urban and agricultural reservoirs in the southeastern states (Van Metre and Callender, 1997; Van Metre, Callender, and Fuller, 1997).

Phase I concentrations of chlordane in surficial sediments were less than method detection limits in samples from four of eight sites in the main body of the lake (Jones and others, 1997). The concentration was $7.0 \mu \mathrm{g} / \mathrm{kg}$ at site MCL-12 in the NAS inlet. Concentrations in Cottonwood Bay ranged from less than 2.0 to $16.0 \mu \mathrm{g} / \mathrm{kg}$ with detections at seven of eight sites. Phase II samples from the NAS inlet had chlordane concentrations that ranged from less than 0.1 to $22.0 \mu \mathrm{g} / \mathrm{kg}$ with a median of $9.3 \mu \mathrm{g} / \mathrm{kg}$ and detections at six of seven sites.

Phase I dieldrin concentrations were below the method detection limit of $0.1 \mu \mathrm{g} / \mathrm{kg}$ in five of eight samples in the main body of the lake. The three sites where dieldrin was detected had concentrations of 0.2 to $0.5 \mu \mathrm{g} / \mathrm{kg}$. Four of eight sites in Cottonwood Bay had measurable amounts of dieldrin with maximum concentrations of 1.7 and $2.4 \mu \mathrm{g} / \mathrm{kg}$ at sites MCL-6 and MCL-7, respectively. Phase II dieldrin concentrations in the NAS inlet ranged from 0.22 to $0.55 \mu \mathrm{g} / \mathrm{kg}$ with detections at six of seven sites. In comparison, dieldrin concentrations in recently deposited sediments in White Rock Lake on the north side of Dallas ranged from 0.3 to $0.7 \mu \mathrm{g} / \mathrm{kg}$ (Van Metre and Callender, 1997).

Streambed sediment was collected during both sampling phases for organochlorine pesticide analysis. Sediment from three sites, one each on three small streams along the northeastern boundary of NAS, was sampled during Phase I (fig. 1; NAS-2, NAS-3, and NAS-4). Four streambed sediment sites were sampled during Phase II, two downstream from two Phase I sites on the streams along the NAS boundary and the remaining two on the north and south forks of Cottonwood Creek (fig. 2; M2.46 and M2.47; M2.23 and M2.48). Organochlorine pesticide concentrations were relatively large for the sites on and near NAS and on the north fork of Cottonwood Creek, similar to concentrations in lake bottom sediments in the NAS inlet and to suspended sediment concentrations from the north fork of Cottonwood Creek. No organochlorine pesticides were detected in the more rural south fork of Cottonwood Creek. Chlordane concentrations for streambed sediment sampling sites on and near the NAS ranged from 6.8 to $31 \mu \mathrm{g} / \mathrm{kg}$ with the largest value at NAS -4 . The chlordane concentration for the north fork of Cottonwood Creek was $36 \mu \mathrm{g} / \mathrm{kg}$, and the concentration for the south fork was below the method detection limit of $1.0 \mu \mathrm{g} / \mathrm{kg}$. The difference in concentrations between the two sites reflects the different land uses within the watersheds and the largely urban sources of chlordane that contribute to recent sediment (Van Metre, Callender, and Fuller, 1997). Dieldrin concentrations were less than method detection limits for the three Phase I samples. Dieldrin was detected in two Phase II samples downstream from NAS at a concentration of $0.5 \mu \mathrm{g} / \mathrm{kg}$ in both samples and in one sample from the north fork of Cottonwood Creek at a concentration of $1.1 \mu \mathrm{g} / \mathrm{kg}$.

Gravity cores MCL-4, Bay-13, and M2.40 were analyzed for organochlorine pesticides. Total DDT concentrations in MCL-4 peaked at a concentration of $5.9 \mu \mathrm{g} / \mathrm{kg}$ in a sample deposited in about 1966 and decreased to less than $0.7 \mu \mathrm{g} / \mathrm{kg}$ ( $p, p^{\prime}$-DDE, $0.3 \mu \mathrm{g} / \mathrm{kg}$; $p, p^{\prime}$-DDT, less than $0.2 \mu \mathrm{g} / \mathrm{kg}$; and $p, p^{\prime}$-DDD, less than $0.2 \mu \mathrm{g} / \mathrm{kg}$ ) in the most recent sample. Bay-13 (east 


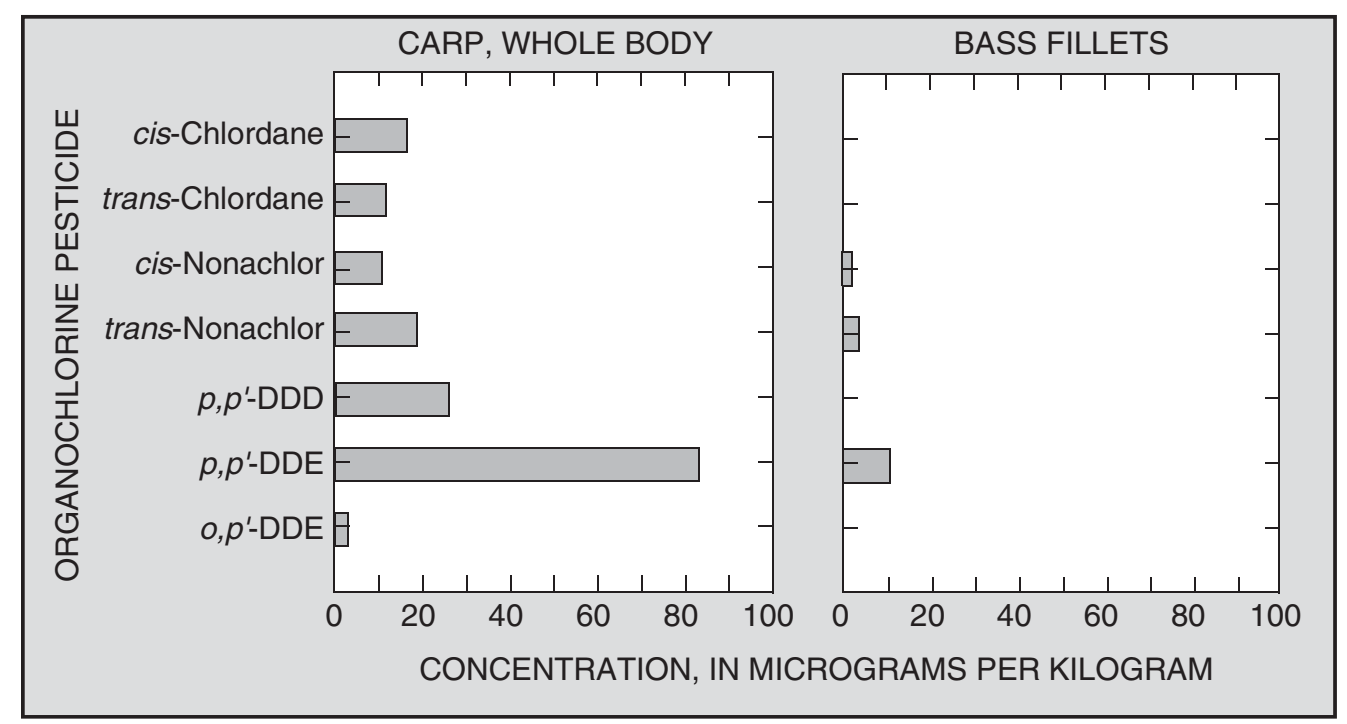

Figure 28. Mean concentrations of organochlorine pesticides detected in composite fish tissues sampled in Phase I.

Cottonwood Bay) had a maximum total DDT concentration of $37 \mu \mathrm{g} / \mathrm{kg}$ in a sample deposited in about 1967. The total DDT concentration in surficial sediments at Bay-13 was less than $10 \mu \mathrm{g} / \mathrm{kg}$. The maximum total DDT concentration in M2.40 (NAS inlet) was $21.4 \mu \mathrm{g} / \mathrm{kg}$ in a sample deposited in about 1960 . Concentrations decrease to $2.1 \mu \mathrm{g} / \mathrm{kg}$ in the most recent sample. Temporal patterns and the magnitude of concentrations of total DDT at all three sites are similar to other reservoirs in the southeastern United States (Van Metre, Callender, and Fuller, 1997).

Chlordane and dieldrin were detected less frequently in the Mountain Creek Lake cores than the DDT degradation products $p, p^{\prime}$-DDD and $p, p^{\prime}$-DDE. Chlordane was not detected in any of 13 samples from MCL -4 or in any of seven samples from Bay-13. Chlordane was detected in the six most recently deposited samples from M2.40, beginning at 25 to $30 \mathrm{~cm}$ and continuing to the surface, representing deposition since about 1975. The chlordane concentration peaked at $4.8 \mu \mathrm{g} / \mathrm{kg}$ in the 5- to $10-\mathrm{cm}$ interval, deposited in about 1990. A similar chlordane trend was reported for White Rock Lake (Van Metre and Callender, 1997). Dieldrin was not detected in any of the samples from MCL-4 and Bay-13. Core M2.40 had dieldrin concentrations greater than method detection limits for 12 of 15 sampling intervals, although concentrations were consistently small, ranging from 0.14 to $0.51 \mu \mathrm{g} / \mathrm{kg}$.

\section{Organochlorine Pesticides in Fish}

The most commonly detected organochlorine pesticides in fish tissue from Mountain Creek Lake were DDT degradation products and various components of technical chlordane (Jones and others, 1997, p. I-41, II-34). In composite samples from Phase I, organochlorine pesticides were detected more frequently and at larger concentrations in common carp than in largemouth bass (fig. 28). Seven organochlorine pesticides were detected in whole-body common carp samples, and three organochlorine pesticides were detected in the largemouth bass fillets, which probably reflects the lower lipid content of the fillets. Mean p,p'DDD and p,p'-DDE concentrations in whole-body common carp were larger than those of any of the other organochlorines. DDE, like other organochlorine pesticides, has low water solubility $\left(0.040 \mathrm{mg} / \mathrm{L}\right.$ at $\left.20^{\circ} \mathrm{C}\right)$ but high lipid solubility. Water-to-fish-tissue bioconcentration factors (BCF) for DDE are as high as 11,000 (Verschueren, 1983). The chlordane isomers, cis- and trans-nonachlor occurred at larger concentrations in whole-body common carp than largemouth bass, and cis- and trans-chlordane were detected only in wholebody common carp in Phase I.

All of the organochlorine pesticides detected in Phase I composite tissue samples also were detected in the individual tissue samples in Phase II. The number of detections ranged from two organochlorine pesticides in largemouth bass fillets to eight in eviscerated channel 


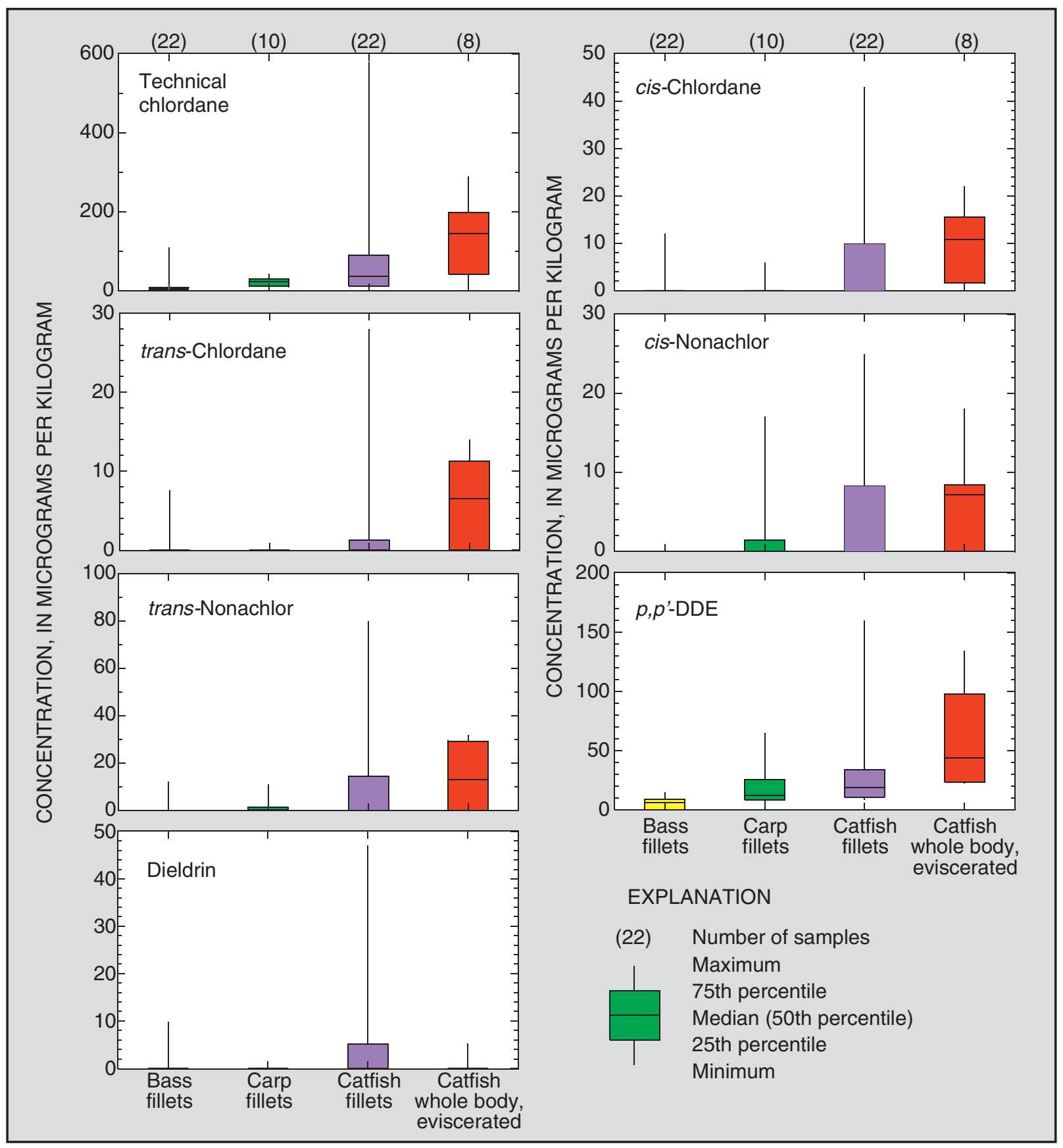

Figure 29. Distribution of organochlorine pesticide concentrations detected in fish sampled in Phase II.

catfish fillets. Dieldrin commonly was detected in tissue samples from Phase II. Technical chlordane was added as a separate constituent for analysis in Phase II and occurred at the largest average concentrations of any organochlorine pesticide in all four tissues media. Median concentrations of technical chlordane ranged from $11.2 \mu \mathrm{g} / \mathrm{kg}$ in bass fillets to $144 \mu \mathrm{g} / \mathrm{kg}$ in eviscerated channel catfish. Major components of tech- nical chlordane include cis-chlordane (19 percent), trans-chlordane (24 percent), cis- and trans-nonachlor (7 percent each), and heptachlor epoxide (10 percent) (Irwin, 1988). Median and maximum concentrations of detected organochlorine pesticides were greater in catfish fillets or eviscerated whole-body catfish than in common carp or largemouth bass fillets (fig. 29). Some of the difference in concentrations of these 
organochlorine pesticides among fish samples could be attributed to the larger lipid content in the channel catfish whole-body and fillet samples than in the bass or common carp fillets. Mean or median lipid content was 3.9 percent in whole-body channel catfish, 3.0 percent in channel catfish fillets, 1.5 percent in common carp fillets, and 0.56 percent in largemouth bass fillets. Organochlorine pesticides are more lipid soluble than water soluble, and as such, organochlorine pesticide concentrations generally are larger in tissue with a larger lipid content.

\section{Sources of Organochlorine Pesticides}

Organochlorine pesticides detected in Mountain Creek Lake are widespread in the environment and frequently detected at similar or greater levels in urban lakes or reservoirs (Eisenreich and others, 1989; Van Metre, Callender, and Fuller, 1997). Additionally, a possible source of pesticides for the NAS-1 drainage area is a site identified by EnSafe/Allen \& Hoshall (1996b) as Group 12. Group 12 once contained a sewage treatment plant and possibly a sludge-drying bed. An area of soil and ground water at the site contaminated with pesticides has been mapped by EnSafe. The pesticides detected that exceeded the Risk Reduction Standard 2-Industrial (RRS2-IND) are dieldrin, aldrin, DDT, DDD, and DDE. (EnSafe/Allen \& Hoshall, 1996b).

\section{Occurrence, Trends, and Sources of Polychlorinated Biphenyls}

PCBs were first synthesized in the laboratory in 1929, and from 1930 to 1974 an estimated $5.94 \times 10^{8}$ kilograms $(\mathrm{kg})$ were produced (National Academy of Sciences, 1979). Annual PCB sales in the United States peaked at 36,530 metric tons in 1970 and declined to about one-half that amount by 1973 following the voluntary ban on PCB use in open systems in 1971 (Peakall, 1975). In 1979 all new uses of PCBs were banned (National Academy of Sciences, 1979). PCBs have been used as plasticizers, as hydraulic lubricants in gas turbines and vacuum pumps, in heat-transfer systems, and as dielectric fluids in electrical capacitors and transformers. A biphenyl is two carbon rings attached by a carbon-carbon bond. There are 209 possible combinations in which chlorine atoms can attach to the biphenyls. Each of these unique configurations is known as a PCB congener; congeners differ in their physical and chemical characteristics (National Academy of Sciences, 1979). PCBs were formulated and sold as Aroclors, which are complex mixtures of as many as 60 to 80 congeners at analytically detectable levels (Bedard and others, 1987). PCBs generally are highly resistant to chemical or biological transformation. Reductive dechlorination of PCBs has been demonstrated (Alder and others, 1993); however, it proceeds very slowly, particularly with the more highly chlorinated congeners.

\section{PCBs in Stormwater}

PCBs were not detected in any of the 30 stormwater samples at an MRL of $1.0 \mu \mathrm{g} / \mathrm{L}$ (Raines and others, 1997). PCBs were not analyzed at the four lake-water sampling sites. Lack of detections of PCBs in stormwater is common (for example, Baldys and others, 1998) because PCBs are very hydrophobic. $\mathrm{K}_{\mathrm{ow}}$ values reported for PCBs are 2.8 for the less chlorinated Aroclor 1221, 6.11 for the intermediate chlorinated Aroclor 1248, and 6.91 for the more chlorinated Aroclor 1260 (Montgomery, 1991). For Aroclor 1260, a $\mathrm{K}_{\mathrm{ow}}$ of 6.91 means that about 8 million times more PCB was measured in the $n$-octanol phase than in the water phase. The more chlorinated PCBs are both more persistent and more hydrophobic. It is, therefore, expected that PCBs will partition strongly to sediment organic matter and biota and that water concentrations will be small.

PCBs were detected in stormwater suspended sediment samples from the east and west lagoons (table 11, at end of report). Concentrations of total PCBs (the three Aroclors quantified, Aroclors $1242+$ $1254+1260$; for computation of total PCBs, nondetections of one or more Aroclors were treated as zero values) in the two west lagoon outfall samples were 650 and $248 \mu \mathrm{g} / \mathrm{kg}$. The concentration in a suspended sediment sample from the east lagoon outfall was $45 \mu \mathrm{g} / \mathrm{kg}$, and PCBs were not detected in suspended sediment samples from the north and south forks of Cottonwood Creek. The MRLs varied among samples and were relatively high; for example, the MRLs for three PCB Aroclors in suspended sediment were all $25 \mu \mathrm{g} / \mathrm{kg}$ in the south fork sample. The variability in MRLs is a consequence of variable sample masses recovered from stormwater. Despite the variability in MRLs, it is still apparent that larger concentrations of PCBs occurred in suspended sediments from NWIRP, particularly the west lagoon, than from the reference sites on Cottonwood Creek. 


\section{PCBs in Sediment}

PCBs were detected in all surficial (top $3 \mathrm{~cm}$ ) lake-bottom sediment samples collected from Mountain Creek Lake (Jones and others, 1997, p. I-14, II-18). PCB concentrations in surficial bottom sediments in Cottonwood Bay and in the NAS inlet are about 1 to 2 orders of magnitude larger than in the middle and upper parts of the lake (fig. 30). Concentrations in Phase I samples in the central and east bay ranged from 31 to $110 \mu \mathrm{g} / \mathrm{kg}$ in samples collected in June 1994 and analyzed using the method of Wershaw and others (1987). Concentrations in samples collected in October and November 1994 in the same area ranged from 64 to 800 $\mu \mathrm{g} / \mathrm{kg}$ using the method of Foreman and others (1995). Part of the explanation for the large concentrations in the second set of samples could be that the second method uses a more aggressive chemical extraction procedure. Concentrations in the west end of Cottonwood Bay and in the main body of the lake are $20 \mu \mathrm{g} / \mathrm{kg}$ or less in Phase I samples, except at site MCL-12 $(99 \mu \mathrm{g} / \mathrm{kg})$ near the NAS shoreline in the NAS inlet (fig. 30).

Phase II sampling added more spatial detail in Cottonwood Bay and along the NAS shoreline. PCB concentrations in various sediment samples are summarized in table 11. The largest concentrations in the lake were in central and east Cottonwood Bay and in the NAS inlet. Concentrations decreased down Cottonwood Bay (to the southwest) and in the canal and were the lowest in the main part of Mountain Creek Lake and in Cottonwood Creek streambed sediment samples. The mean concentrations of PCBs in east and central Cottonwood Bay were 271 and $313 \mu \mathrm{g} / \mathrm{kg}$, respectively, compared to a mean of $20 \mu \mathrm{g} / \mathrm{kg}$ in samples from the main lake, excluding samples from near the NAS shoreline, indicating that concentrations were elevated by a factor of about 15 in east and central Cottonwood Bay compared to the main part of the lake. The PCB concentration in the north fork of Cottonwood Creek was $5.8 \mu \mathrm{g} / \mathrm{kg}$. PCBs were not detected at an MRL of $1.0 \mu \mathrm{g} / \mathrm{kg}$ for each of the three Aroclors in the sample from the south fork of Cottonwood Creek. In comparison, the PCB concentration in a surficial sediment sample from White Rock Lake collected in 1996 was $14 \mu \mathrm{g} / \mathrm{kg}$. PCB concentrations in White Rock Lake, Cottonwood Creek, and the main part of Mountain Creek Lake indicate that about $20 \mu \mathrm{g} / \mathrm{kg}$ is typical for recent lake sediments in urban Dallas.

Concentrations of PCBs in the NAS inlet ranged from less than $3.5 \mu \mathrm{g} / \mathrm{kg}$ (Aroclor $1260=1.5$, Aroclor
1254 and Aroclor 1242 less than $1.0 \mu \mathrm{g} / \mathrm{kg}$ ) to 700 $\mu \mathrm{g} / \mathrm{kg}$ (fig. 30b, d). Four of six Phase II surficial sediment samples from the NAS inlet had PCB concentrations greater than $100 \mu \mathrm{g} / \mathrm{kg}$. Unexpectedly, PCB concentrations did not correlate with percent finegrained material; the largest concentration was in a sample that was mostly sand (M2.42), and concentrations varied greatly regardless of percent fine-grained material. Concentrations in seven Phase II surficial sediment samples that were 100 to $300 \mathrm{~m}$ from shore ranged from less than 4.6 to $700 \mu \mathrm{g} / \mathrm{kg}$ with a median of $110 \mu \mathrm{g} / \mathrm{kg}$.

Another small area with larger PCB concentrations is the inlet just east of the main runway (the runway inlet) where concentrations were 220 and $120 \mu \mathrm{g} / \mathrm{kg}$ in two samples (fig. 30b). Concentrations decrease rapidly with distance from shore as indicated by a Phase I concentration of $7.0 \mu \mathrm{g} / \mathrm{kg}$ at site MCL-10, about $100 \mathrm{~m}$ south of the shoreline (fig. 30a).

Historical trends in PCBs at core MCL-4 in the middle of Mountain Creek Lake (fig. 31) are similar to historical trends in sediment cores from White Rock Lake (Van Metre and Callender, 1997). The maximum PCB concentration in the White Rock Lake core was $21 \mu \mathrm{g} / \mathrm{kg}$ in a sample deposited in about 1970, when PCB use in the United States peaked. The maximum concentration in MCL-4 was $11 \mu \mathrm{g} / \mathrm{kg}$, also in a sample deposited in about 1970. Concentrations in both cores since 1970 follow a characteristic decreasing trend observed in other reservoirs (Van Metre and others, 1998).

Maximum PCB concentrations in three samples from the middle part of core Bay-13 from Cottonwood Bay (fig. 31) are 2,100 to $4,000 \mu \mathrm{g} / \mathrm{kg}$, greatly exceeding historical concentrations in the other sediment cores and surficial concentrations in all parts of Mountain Creek Lake. Recently deposited sediments (the top of the cores) had much smaller concentrations, $3 \mu \mathrm{g} / \mathrm{kg}$ in the core from the main body of the lake (MCL-4) and $300 \mu \mathrm{g} / \mathrm{kg}$ in the core from Cottonwood Bay (Bay-13). These trends indicate very large historical PCB inputs and large decreases in PCB inputs in recent years. Three samples from core MCL-7 show a similar temporal trend in PCBs as indicated at Bay-13 (fig. 31). The temporal record is less complete for PCBs than for heavy metals in the Cottonwood Bay cores (fewer samples were analyzed); however, similar general trends are indicated, with the largest concentrations of PCBs in sediments coincident with the time period of pointsource discharges to the west lagoon (pre-1974) and a large decrease in concentrations in recent sediments. 


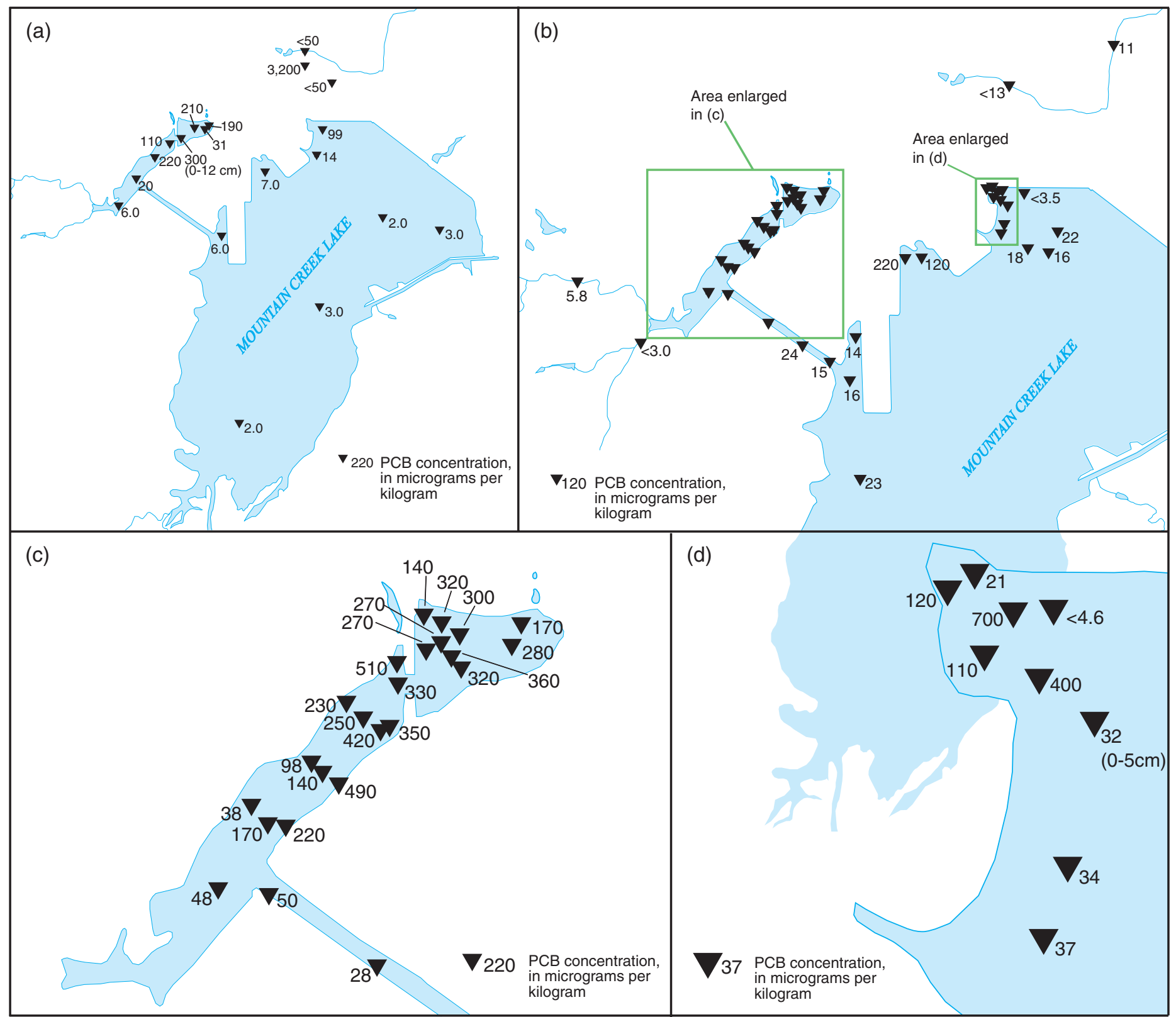

Figure 30. PCB concentrations in top 3 centimeters of lake bottom sediment from (a) Phase I sampling; (b) Phase II sampling; (c) Phase II Cottonwood Bay sampling; and (d) Phase II NAS inlet sampling. 


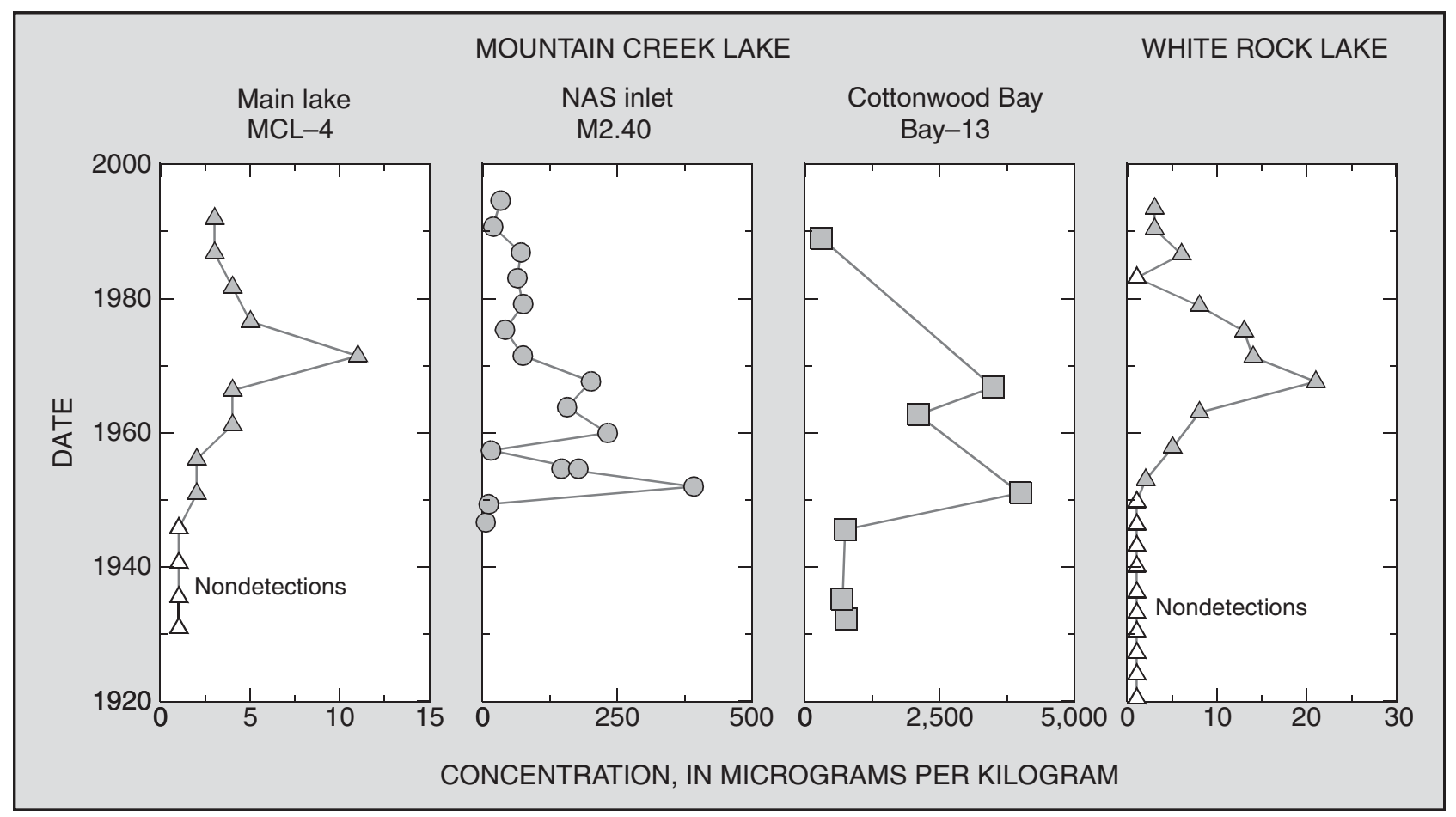

Figure 31. Trends in PCB concentrations in Mountain Creek Lake (cores MCL-4, M2.40, Bay-13) and in White Rock Lake, Dallas Texas.

A more complete PCB record is available for core M2.40 in the NAS inlet sampled during Phase II (fig. 31). PCB concentrations were small (4 and $10 \mu \mathrm{g} / \mathrm{kg})$ at the bottom of the core in samples deposited in the mid1940s. Concentrations increased dramatically in the early 1950 s to a peak of $391 \mu \mathrm{g} / \mathrm{kg}$ in about 1952 and generally remained above $100 \mu \mathrm{g} / \mathrm{kg}$ until about 1970 . The mean concentration of the seven samples deposited from about 1952 to 1970 is $188( \pm 113) \mu \mathrm{g} / \mathrm{kg}$. The concentration has decreased since 1970 and was $32 \mu \mathrm{g} / \mathrm{kg}$ in the most recent sample at M2.40. The pattern at M2.40 is a fairly typical temporal trend that is consistent with historical use and restrictions on use of PCBs. Although the concentrations at M2.40 are much larger than those in White Rock Lake sediments, they are comparable to concentrations in reservoir cores from Lakes West Point and Harding downstream from Atlanta, Ga., on the Chattachoochee River (Van Metre, Callender, and Fuller, 1997).

Large concentrations of PCBs were reported for surficial (0- to $60-\mathrm{cm}$ interval) sediments from the west lagoon on NWIRP (table 11). PCBs also occur in bottom sediments in the east lagoon-concentrations were highly variable with two detections, 760 and 720 $\mu \mathrm{g} / \mathrm{kg}$, and four nondetections. Concentrations in the lagoons are similar to, or larger than, concentrations in deeper (older) sediments in cores Bay-13 and MCL-7. Although no PCBs were detected in 1994-96 stormwater samples at the lagoon outfalls (Raines and others, 1997), relatively large concentrations were measured in suspended sediment samples collected during storms in 1997. PCB concentrations in suspended sediment from the west lagoon (650 and $248 \mu \mathrm{g} / \mathrm{kg}$ ) and from the east lagoon $(45 \mu \mathrm{g} / \mathrm{kg})$ are in the same magnitude range as surficial sediment concentrations in east and central Cottonwood Bay (table 10). Concentrations decreased systematically from the central bay to the west bay to Cottonwood Creek and from the west bay through the canal to the main lake (fig. 30; table 11).

\section{PCBs in Fish}

PCBs were detected in all fish-tissue composite samples from Phase I and in 61 of 62 individual fishtissue samples from Phase II (Jones and others, 1997, p. I-41, II-34). Concentrations of total PCBs in fish from Phase I ranged from $63 \mu \mathrm{g} / \mathrm{kg}$ in a largemouth bass fillet composite sample from the upper lake to 4,200 $\mu \mathrm{g} / \mathrm{kg}$ for a carp composite sample from the NAS inlet. Total PCB concentrations were larger in largemouth 


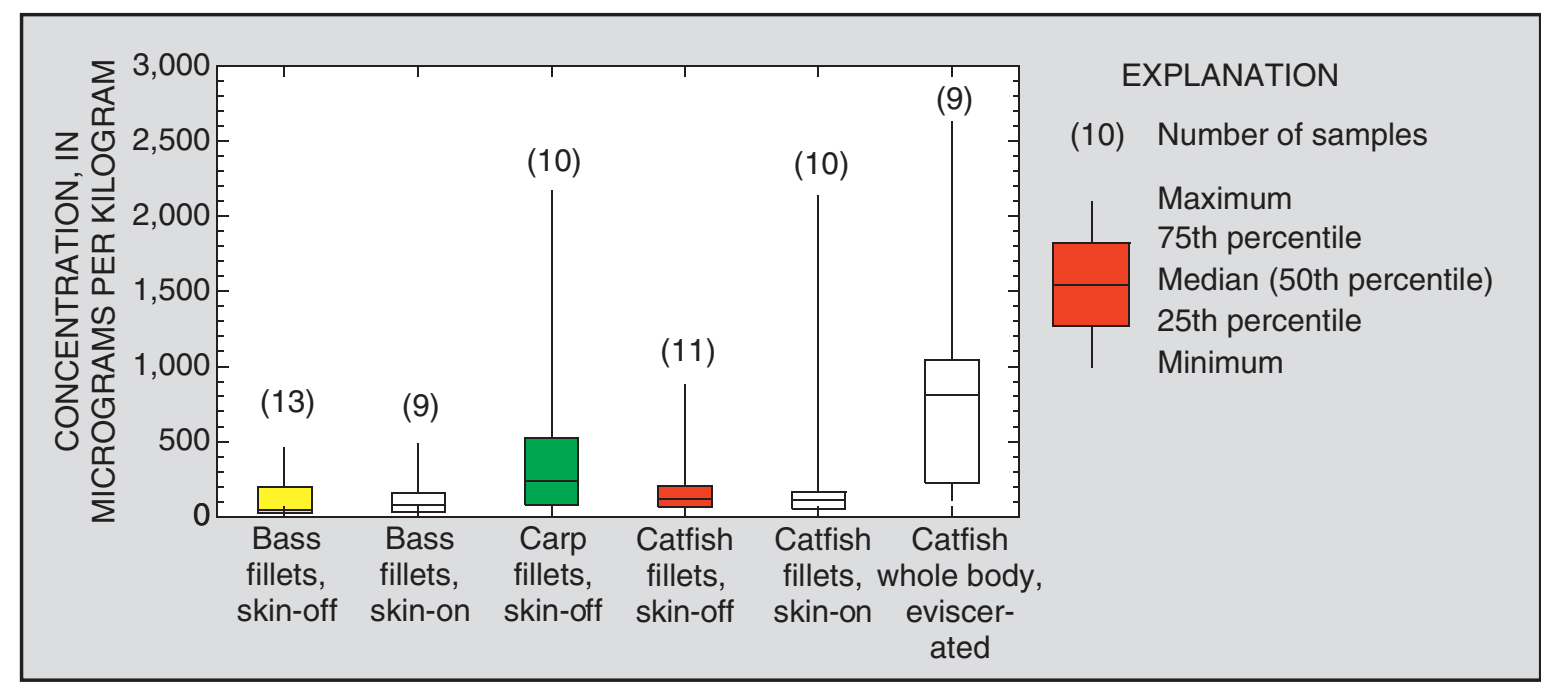

Figure 32. Distribution of PCB concentrations in fish tissues.

bass fillets and whole-body common carp from the NAS inlet and Cottonwood Bay than from the upper lake. Concentrations in samples from NAS inlet, Cottonwood Bay, and upper lake differed by as little as a factor of 2 to as much as a factor of 9 .

PCB Aroclors 1242, 1254, and 1260 were quantified in fish-tissue samples from Phase II. Aroclor 1260 concentration was larger than the other Aroclors in every tissue sample from Phase II; and for every sample with detections of the three Aroclors, the order of concentration from largest to smallest was always 1260 , 1254 and 1242. Concentrations of Aroclor 1260 in individual samples ranged from $2,200 \mu \mathrm{g} / \mathrm{kg}$ for an eviscerated channel catfish collected in Cottonwood Bay to a nondetection for a skin-off channel catfish fillet from the upper lake. Concentrations of Aroclor 1254 ranged from 11 nondetections distributed across all tissue sample types and representing all areas of the lake to a maximum of $470 \mu \mathrm{g} / \mathrm{kg}$ in a common carp fillet from near the runway inlet. Concentrations of Aroclor 1242 ranged from nondetections in more than one-half the samples to $33 \mu \mathrm{g} / \mathrm{kg}$ in a channel catfish fillet from the upper lake. Median concentrations of Aroclors 1260 and 1254 were greatest in eviscerated channel catfish; the maximum average concentration of Aroclor 1242 was in common carp fillets.

Total PCB concentrations (the sum of Aroclors 1242,1254 , and 1260) were not significantly different between skin-on and skin-off largemouth bass fillets (Wilcoxon rank-sum test [Helsel and Hirsch, 1992]; p $>.05$ ) or between skin-on and skin-off channel catfish fillets ( $p>.05$; fig. 32). Total PCB concentrations were significantly different in fillets from all species versus eviscerated channel catfish (multiple stage KruskalWallis test [Helsel and Hirsch, 1992]; $\mathrm{p}<.05$ ).

\section{Sources of PCBs}

As with the heavy metals, all conditions necessary to identify source have been demonstrated for PCBs in Cottonwood Bay. PCB concentrations in Cottonwood Bay are elevated relative to those in the main lake and to those at urban reference sites. PCB concentrations in the west and east lagoons on NWIRP are similar to, or greater than, those in the bay. Greater concentrations in dated sediment cores are coincident in time with large point-source discharges to the west lagoon. PCBs were not identified as a component of those discharges; however, PCBs commonly are in waste oil and petroleum products, one of the discharge categories identified (table 3). Additionally, the high (particulate) organic carbon content of sewage effluent provides an excellent transport medium for hydrophobic organic contaminants like PCBs. Finally, PCB concentrations in three suspended sediment samples collected in 1997 from the west and east lagoon outfalls were similar to concentrations in surficial bottom sediments in the bay and directly demonstrate transport to the bay. Therefore, the NWIRP lagoons, principally the west lagoon, are indicated as the source of the elevated levels of PCBs in bottom sediments in Cottonwood Bay. 
Two other areas of Mountain Creek Lake had elevated PCB concentrations in bottom sediments. PCB concentrations in the NAS inlet had a mean of $226 \mu \mathrm{g} / \mathrm{kg}$ and ranged from less than 3.5 to $700 \mu \mathrm{g} / \mathrm{kg}$. PCB concentrations decrease rapidly with increasing distance from shore. SWMU Group 12 is a possible source for the PCB contamination in the NAS inlet, with reported soil concentrations of Aroclor 1260 of 95 and $1,100 \mu \mathrm{g} / \mathrm{kg}$ (EnSafe/Allen \& Hoshall, 1996b). The second area of large PCB concentrations near NAS is the runway inlet, where concentrations were 220 and 120 $\mu \mathrm{g} / \mathrm{kg}$ in two samples. A likely source is a former transformer storage site (SWMU 85) identified on NAS just north of site M2.31, with reported soil concentrations of Aroclor 1260 of 22, 400, and 3,400 $\mu \mathrm{g} / \mathrm{kg}$ (EnSafe/ Allen \& Hoshall, 1996b). Concentrations decrease rapidly with distance from shore.

The transport pathway from the two NAS on-site PCB sources to the areas with elevated concentrations in bottom sediments at the NAS and runway inlets presumably is erosion and transport of contaminated soils by stormwater runoff. This transport pathway is difficult to verify because, unlike the NWIRP lagoons, flow from these contaminated areas to the lake is not in defined channels and does not pass any of the stormwater monitoring stations where suspended sediments were collected. On the basis of spatial proximity, temporal trends in core M2.40 of large historical concentrations and stable sedimentation patterns over a long time period, the presence of on-site sources, and the lack of plausible alternative sources, NAS is identified as the source of PCBs in bottom sediments at the NAS and runway inlets.

\section{Sediment and Contaminant Accumulation in Cottonwood Bay}

The largest concentrations of contaminants in surficial sediments in Mountain Creek Lake, which include heavy metals (cadmium, chromium, copper, lead, mercury, nickel, silver, zinc), PAHs, and PCBs, were in Cottonwood Bay. Because of the occurrence of these contaminants in the bay, a sedimentation survey was done to estimate the total mass of sediment and (using measured concentrations) to estimate the mass of contaminants in storage in the bay. The total thickness of lacustrine sediments was determined at each of the Phase I and II sediment sampling sites using gravity cores during sampling. Sediment thickness was determined at selected additional sites using metal bars pushed through the sediments and using gravity cores during July and August 1996. Thicknesses were contoured (fig. 33), constrained by a zero-thickness contour near shore, and converted to sediment volume by a computer program. Sediment volume was converted to mass using the bulk density calculated from measured porosities in selected cores. An estimated 38,000,000 kg of sediment accumulated in east Cottonwood Bay from 1928, when the dam to form Mountain Creek Lake was built, to 1995 . An estimated 29,000,000 kg accumulated in central Cottonwood Bay over the same time period.

Contaminant accumulation rates in a core can be estimated by multiplying the mass accumulation rate of sediment for a given time interval times the concentration of the contaminant in the interval. This method is illustrated in figure 34 using silver in core Bay-13. Because both the sedimentation rate and the silver concentration decreased after 1974, the product of the two, silver accumulation rate, decreased substantially.

Masses of selected contaminants in storage in bottom sediments in east and central Cottonwood Bay were estimated for two time periods, 1940-74 and 1974-95. The estimates were made for the earlier period by (1) multiplying the fraction of core mass accumulated during the 1940-74 interval for core Bay-13 (73 percent of the core) times the total mass of sediment in each part of the bay, then (2) multiplying the mean concentration of the selected contaminant in the 1940-74 period of cores MCL-7 and Bay-13 times the sediment mass. The first step assumes that the temporal pattern in sedimentation at core Bay-13 is representative of sedimentation over east and central Cottonwood Bay. The second step in the calculation assumes that the contaminant concentrations in the deeper sediment layers over the whole upper bay are equal to the average concentrations at MCL-7 and Bay-13. Both of these assumptions lead to considerable uncertainty in the estimates of total contaminant masses in storage in the older sediment interval.

The estimated mass of sediment in storage for the latter time period, 1974-95, was made by multiplying the fraction of core mass accumulated during the interval in core Bay-13 (9 percent of the core) times the total mass of sediment in each part of the bay. This step makes the same assumptions as the comparable step for the earlier time period. Contaminant masses in these sediment intervals then were estimated by multiplying the mean contaminant concentrations in surficial sediment samples times the sediment mass in each part of 


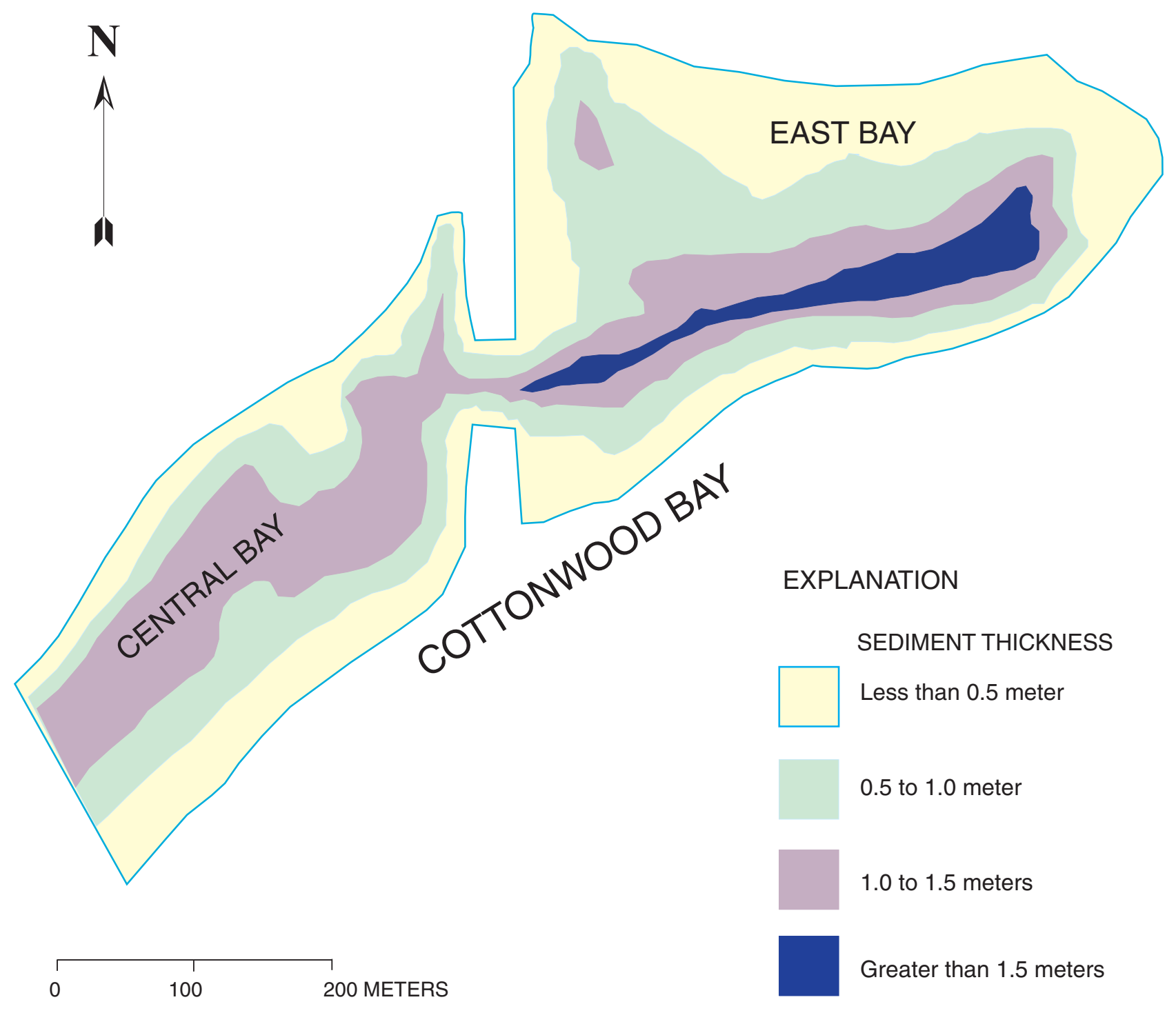

Figure 33. Thickness of lacustrine sediment in central and east Cottonwood Bay.

the bay. This step should lead to more accurate estimates than the comparable step for the earlier time period because the surficial samples were more numerous and more uniformly distributed over each area of the bay. The comparable step for the earlier period used concentrations at only two locations, Bay-13 and MCL-7.

Masses of contaminants in storage then were divided by the time interval represented to estimate annual contaminant accumulation rates (table 12, at end of report). Two conclusions are apparent from table 12. The first is that most of the contaminant accumulation to Cottonwood Bay occurred before 1974 when active waste discharge to the NWIRP lagoons was occurring.
Total contaminant mass accumulations typically are 1 to 2 orders of magnitude greater for the 1940-74 period than the 1974-95 period. The second conclusion is that although contaminant accumulation rates have been greatly reduced, some contaminant movement to the bay is still occurring. The primary source of most of the contaminants to bay sediments is stormwater runoff passing through the east and west lagoons on NWIRP. In the case of PAHs, transport from urban areas by way of Cottonwood Creek also is a contributor. Continuing off-site transport was verified by measured chemical concentrations in suspended sediments collected during stormflow from the east and west lagoons. 


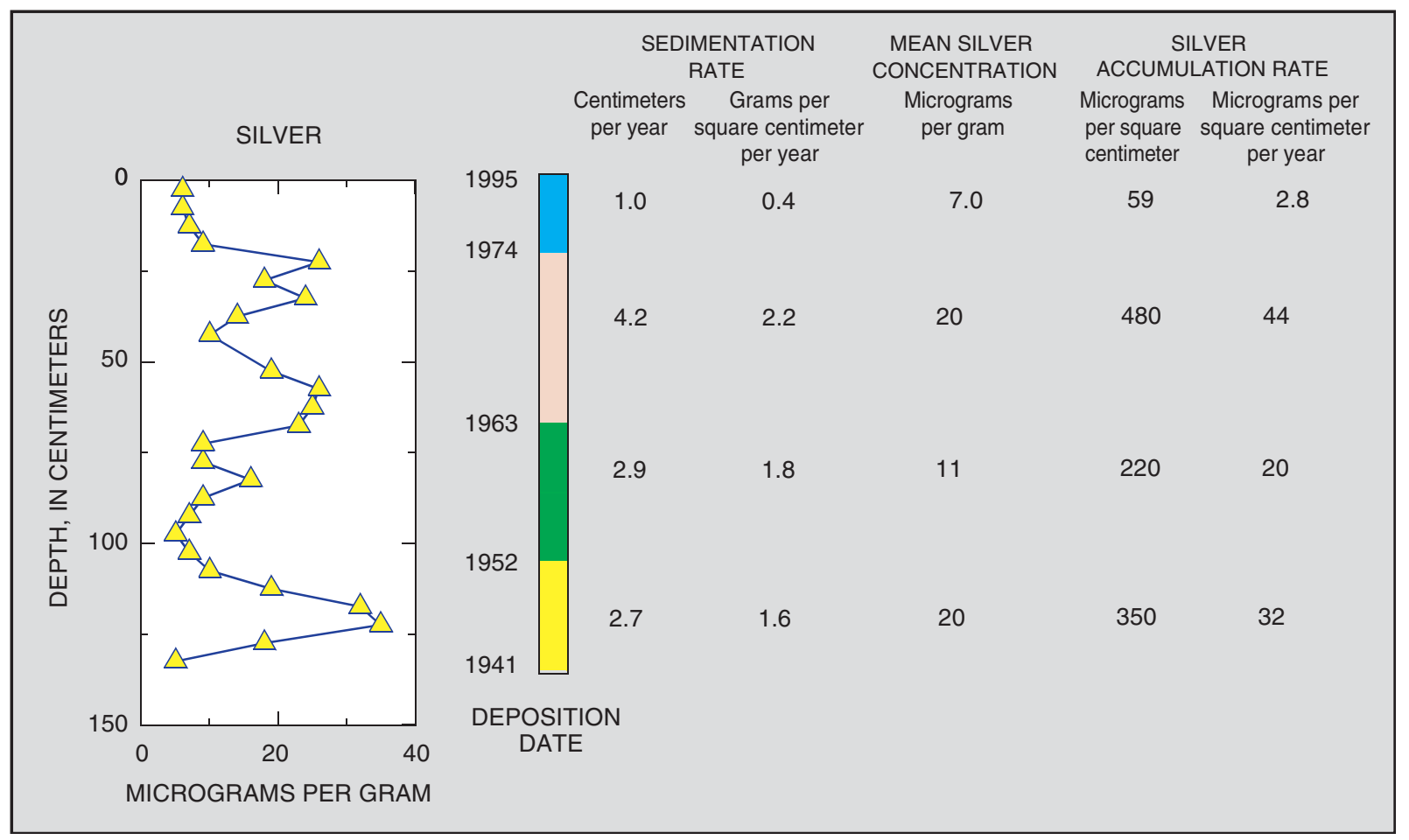

Figure 34. Mass accumulation rates of silver in Bay-13 core.

\section{SUMMARY}

The occurrence, trends, and sources of numerous inorganic and organic contaminants were assessed in Mountain Creek Lake, a reservoir in Dallas, Tex. The study was done in cooperation with the Southern Division Naval Facilities Engineering Command and was prompted by the Navy's concern for potential off-site migration of contaminants from two facilities, the NAS and NWIRP. Both facilities are on the shores of Mountain Creek Lake. The objective was to determine the occurrence and distribution of contaminants in Mountain Creek Lake. Sampling primarily was in Mountain Creek Lake (including Cottonwood Bay) but also was done in stormwater outfalls from the Navy facilities, nearby urban streams, and small streams draining NAS.

This report presents and discusses the occurrence of constituents sampled in each of the environmental phases sampled (stormwater [includes suspended sediment], lake water, bottom sediment [includes streambed sediment], and fish tissue). Temporal trends, mass fluxes, and sources are evaluated for selected elements and compounds including heavy metals, VOCs, PAHs, organochlorine pesticides, and PCBs. Trends were identified using dated bottom-sediment cores. Mass fluxes were estimated using data from sediment cores and a sedimentation survey. Potential sources of contaminants in the lake were identified on the basis of (1) identification of a potential source or sources in either the urbanized parts of the watershed or at the Navy facilities; (2) description of a plausible transport pathway from the source(s) to the lake supported, in some cases, by stormwater sampling results; and (3) relation of the source and pathway to the spatial and temporal distribution in the lake. Additionally, in the case of some groups of related organic compounds, chemical "signatures" are used to aid in source identification.

Major findings of this study are:

- Concentrations of selected heavy metals in surficial bottom sediments in Cottonwood Bay were 2 to 4 times greater than main lake and urban reference site concentrations, with the largest concentrations near the NWIRP outfalls. The metals included cadmium, chromium, copper, lead, mercury, nickel, silver, and zinc. Suspended sediments from the NWIRP outfalls contained about the same mixture of heavy metals, in elevated concentrations compared to reference 
sites, as bottom sediments in the NWIRP lagoons and surficial bottom sediments in Cottonwood Bay. These same metals were elevated in deeper sediments deposited historically in Cottonwood Bay, with concentrations of cadmium, chromium, and silver more than 20 times reference concentrations.

- VOCs were detected in stormwater from both Navy facilities, predominantly solvents from NWIRP and fuel-related compounds from NAS. Fuelrelated compounds also were detected in Mountain Creek Lake at two locations, one near the NAS inlet where stormwater from a part of NAS enters the lake and one at the center of the lake. Concentrations at the two lake sites were small, all less than $5 \mu \mathrm{g} / \mathrm{L}$.

- Elevated concentrations of PAHs compared to main lake and urban reference sites, were detected in surficial sediments in Cottonwood Bay. Elevated concentrations of PAHs, indicative of urban sources, also were detected in Cottonwood Creek, which drains an urbanized area apart from the Navy facilities. PAH concentrations near the NAS shoreline were not elevated compared to urban reference sites. Larger concentrations of PAHs were detected in deeper, older sediments in Cottonwood Bay than in surficial sediments, indicating historical contaminant inputs were greater. Larger concentrations are associated with the period before improvements in wastewater discharge practices at NWIRP were made. Diagnostic ratios of PAHs indicate that uncombusted fuel sources contribute PAHs to older sediments and that pyrogenic sources of PAHs dominate recently deposited sediments.

- Concentrations of organochlorine pesticides in sediments were small and similar to relatively uncontaminated urban sites like White Rock Lake in Dallas. Fish tissue concentrations also were relatively small.

- PCBs were detected in all surficial bottom sediment samples and in 61 of 62 individual fish tissue samples. PCB concentrations, like some of the heavy metals and PAHs, were largest in surficial sediment samples in Cottonwood Bay near the west and east lagoon outfalls from NWIRP. The mean concentration in surficial sediments of about $300 \mu \mathrm{g} / \mathrm{kg}$ was about an order of magnitude smaller than the concentrations in deeper sediments, deposited in the 1960s or early 1970s, and 1 to 2 orders of magnitude greater than surficial sediment concentrations in main-lake reference sites. PCBs were also elevated in selected samples along the NAS shoreline. PCBs were detected in suspended sediments in stormwater flowing from the east and west lagoons indicating transport to the lake was still occurring in 1997. PCB and selenium concentrations from analyses of this study were large enough to prompt the Texas State Department of Health to issue a fish-possession ban for Mountain Creek Lake in 1996.

- On the basis of dated sediment cores and contaminant discharge histories, contaminant accumulation rates in Cottonwood Bay were much greater historically than recently. Most heavy metals, PAHs, and PCBs that accumulated in the central and eastern parts of Cottonwood Bay appear to have come from the west lagoon on NWIRP. Treated sewage and industrial process wastewater were discharged to the west lagoon from about 1941 to 1974 . Estimated annual contaminant accumulation rates in Cottonwood Bay decreased by 1 to 2 orders of magnitude after 1974, when most point-source discharges to the west lagoon ceased.

\section{REFERENCES}

Agency for Toxic Substances and Disease Registry, 1994, 1993 CERCLA priority list of hazardous substances that will be the subject of toxicological profiles and support document: Atlanta, U.S. Department of Health and Human Services, Public Health Service, 34 p.

Alder, A.C., Häggblom, M.M., Oppenheimer, S.R., and Young, L.Y., 1993, Reductive dechlorination of polychlorinated biphenyls in anaerobic sediments: Environmental Science and Technology, v. 27, no. 3, p. 530-538.

Baldys, Stanley, III, Raines, T.H., Mansfield, B.L., and Sandlin, J.T., 1998, Urban stormwater quality, eventmean concentrations, and estimates of stormwater pollutant loads, Dallas-Fort Worth area, Texas, 1992-93: U.S. Geological Survey Water-Resources Investigations Report 98-4158, $51 \mathrm{p}$.

Barbaro, J.R., Barker, J.F., Lemon, L.A., and Mayfield, C.I., 1992, Biotransformation of BTEX under anaerobic, denitrifying conditions-Field and laboratory observations: Journal of Contaminant Hydrology, v. 11, p. 245-272. 
Barker, R.A., and Braun, C.L., 2000, Computer-model analysis of ground-water flow and simulated effects of contaminant remediation at Naval Weapons Industrial Reserve Plant, Dallas, Texas: U.S. Geological Survey Water-Resources Investigations Report 00-4197, 44 p.

Bedard, D.L., Wagner, R.E., Brennan, M.J., Haberl, M.L., and Brown, J.F., Jr., 1987, Extensive degradation of Aroclors and environmentally transformed polychlorinated biphenyls by Alcaligenes eutrophus H850: Applied and Environmental Microbiology, v. 53, p. 1,094-1,102.

Blumer, M., and Youngblood, W.W., 1975, Polycyclic aromatic hydrocarbons in soils and recent sediments: Science, v. 188, p 53-55.

Callender, Edward, and Van Metre, P.C., 1997, Reservoir sediment cores show U.S. lead declines: Environmental Science and Technology, v. 31, no. 9, p. 424A-428A.

Crawford, J.K., and Luoma, S.N., 1993, Guidelines for studies of contaminants in biological tissues for the National Water Quality Assessment Program: U.S. Geological Survey Open-File Report 92-494, 69 p.

Durrance, E.M., 1986, Radioactivity in geology_Principles and applications: Chichester, West Sussex, England, Ellis Horwood Ltd., 441 p.

Easley, D.M., Kleopfer, R.D., and Karasea, A.M., 1981, Gas chromatographic spectrometric determination of volatile organic compounds in fish tissues: Journal of Association of Official Analytical Chemists, v. 64, no. 4, p. 653-656.

Eganhouse, R.P., and Gossett, R.W., 1991, Historical deposition and biogeochemical fate of polycyclic aromatic hydrocarbons in sediments near a major submarine wastewater outfall in Southern California, in Baker, R.A., ed., Organic substances and sediments in water: Boca Raton, Fla., Lewis Publishers, p. 191-220.

Eisenreich, S.J., Capel, P.D., Robbins, J.A., and Boubonniere, R., 1989, Accumulation and diagenesis of chlorinated hydrocarbons in lacustrine sediments: Environmental Science and Technology, v. 23, no. 9, p. 1,116-1,126.

Eisler, R., 1985, Selenium hazards to fish, wildlife, and invertebrates-A synoptic review: U.S. Fish and Wildlife Service Biological Report 85(1.5), 57 p.

1987, Polycyclic aromatic hydrocarbon hazards to fish, wildlife, and invertebrates-A synoptic review: U.S. Fish and Wildlife Service Biological Report 85(1.11), $81 \mathrm{p}$.

EnSafe/Allen \& Hoshall, 1995, Base Realignment and Closure Cleanup Plan (BCP) for Naval Air Station, Dallas, Texas: Memphis, Tenn., EnSafe/Allen \& Hoshall.

1996a, Draft RCRA Facility Investigation Report, Naval Weapons Industrial Reserve Plant, Dallas, Texas: Memphis, Tenn., EnSafe/Allen \& Hoshall. 1996b, Interim RFI Report Category B NAS, Dallas, Texas: Memphis, Tenn., EnSafe/Allen \& Hoshall. 1997a, Interim RFI Report Category C NAS, Dallas, Texas: Memphis, Tenn., EnSafe/Allen \& Hoshall. 1997b, Interim RFI Report Category F NAS, Dallas, Texas: Memphis, Tenn., EnSafe/Allen \& Hoshall.

Faires, L.M., 1993, Methods of analysis by the U.S. Geological Survey National Water Laboratory-Determination of metals in water by inductively coupled plasma-mass spectrometry: U.S. Geological Survey Open-File Report 92-634, 28 p.

Fishman, M.J., 1993, Methods of analysis of the U.S. Geological Survey National Water Quality LaboratoryDetermination of inorganic and organic constituents in water and fluvial sediments: U.S. Geological Survey Open-File Report 93-125, 217 p.

Fishman, M.J., and Friedman, L.C., eds., 1989, Methods for determination of inorganic substances in water and fluvial sediments: U.S. Geological Survey Techniques of Water-Resources Investigations, book 5, chap. A1, $545 \mathrm{p}$.

Foreman, W.T., Connor, B.F., Furlong, E.T., Vaught, D.G., and Merten, L.M., 1995, Methods of analysis by the U.S. Geological Survey National Water Quality Laboratory-Determination of organochlorine insecticides and polychlorinated biphenyls in bottom sediment by dual capillary-column gas chromatography with electroncapture detection: U.S. Geological Survey Open-File Report 95-140, 78 p.

Furlong, E.T., Vaught, D.G., Merten, L.M., Foreman, W.T., and Gates, P.M., 1996, Methods of analysis by the U.S. Geological Survey National Water Quality Laboratory-Determination of semivolatile organic compounds in bottom sediment by solvent extraction, gel permeation chromatographic fractionation, and capillary-column chromatography/mass spectrometry: U.S. Geological Survey Open-File Report 95-719, 67 p.

Geological Society of America, 1991, The Geological Society of America rock color chart: Boulder, Colo., 16 p.

Gschwend, P.M., and Hites, R.A., 1981, Fluxes of polycyclic aromatic hydrocarbons to marine and lacustrine sediments in the northeastern United States: Geochimica et Cosmochimica Acta, v. 45, p. 2,359-2,367.

Heit, M., 1985, The relationship of a coal fired power plant to the levels of polycyclic aromatic hydrocarbons (PAH) in the sediment of Cayuga Lake: Water, Air, and Soil Pollution, v. 24, p. 41-61.

Helsel, D.R., and Hirsch, R.M., 1992, Studies in environmental science 49-Statistical methods in water resources: New York, Elsevier, 521 p.

Hem, J.D., 1985, Study and interpretation of the chemical characteristics of natural water ( $3 \mathrm{~d}$ ed.): U.S. Geological Survey Water-Supply Paper 2254, 264 p. 
Hites, R.A., LaFlamme, R.E., Windsor, J.G., Jr., Farrington, J.W., and Deuser, W.G., 1981, Polycyclic aromatic hydrocarbons in an anoxic sediment core from the Pettaquamscutt River (Rhode Island, U.S.A.): Geochimica et Cosmochimica Acta, v. 44, p. 873-878.

Howard, P.H., 1990, Handbook of environmental fate and exposure data for organic chemicals-Volume II. Solvents: Chelsea, Mich., Lewis Publishers, 576 p.

Irwin, R.J., 1988, Impacts of toxic chemicals on Trinity River fish and wildlife: Fort Worth, U.S. Fish and Wildlife Service Contaminant Report, $82 \mathrm{p}$.

Jones, S.A., Van Metre, P.C., Moring, J.B., Braun, C.L., Wilson, J.T., and Mahler, B.J., 1997, Chemical data for bottom sediment, lake water, bottom-sediment pore water, and fish in Mountain Creek Lake, Dallas, Texas, 1994-96: U.S. Geological Survey Open-File Report 97-245, 19 p., 2 app.

Knox, R.C., Sabatini, D.A., and Canter, L.W., 1993, Subsurface transport and fate processes: Boca Raton, Fla., Lewis Publishers, 430 p.

Leiker, T.J., Madsen, J.E., Deacon, J.R., and Foreman, W.T., 1995, Methods of analysis by the U.S. Geological Survey National Water Quality Laboratory-Determination of chlorinated pesticides in aquatic tissue by capillarycolumn gas chromatography with electron-capture detection: U.S. Geological Survey Open-File Report 94-710, 42 p.

Lichte, F.E., Golightly, D.W., and Lamothe, P.J., 1987, Inductively coupled plasma-atomic emission spectrometry, in Baedecker, P.A., ed., Methods for geochemical analysis: U.S. Geological Survey Bulletin 1770, p. B1-B10.

Lucius, J.E., Olhoeft, G.R., Hill, P.L., and Duke, S.K., 1992, Properties and hazards of 108 selected substances1992 edition: U.S. Geological Survey Open-File Report 92-527, 554 p.

Meade, R.H., ed., 1995, Contaminants in the Mississippi River, 1987-92: U.S. Geological Survey Circular 1133, $140 \mathrm{p}$.

Montgomery, J.H., 1991, Groundwater chemicals desk reference-Volume 2: Chelsea, Mich., Lewis Publishers, 944 p.

National Academy of Sciences, 1979, Polychlorinated biphenyls: Washington, D.C., National Academy Press.

Pankow, J.F., Rathbun, R.E., and Zogorski, J.S., 1996, Calculated volatilization rates of fuel oxygenate compounds and other gasoline-related compounds from rivers and streams: Chemosphere, v. 33, no. 5, p. 921-937.

Peakall, D.B., 1975, PCBs and their environmental effects: CRC Critical Reviews in Environmental Control, 469 p.

Raines, T.H., Baldys, Stanley, III, and Lizarraga, J.S., 1997, Characterization of stormwater runoff from the Naval Air Station and Naval Weapons Industrial Reserve Plant, Dallas, Texas, 1994-96: U.S. Geological Survey OpenFile Report 97-402, 80 p.
Rapaport, R.A., Urban, N.R., Capel, P.D., Baker, J.E., Looney, B.B., Eisenreich, S.J., and Gorham, E., 1985, "New" DDT inputs to North America-Atmospheric deposition: Chemosphere, v. 14, p. 1,167-1,173.

Robison, H.W., and Buchanan, T.M., 1984, Fishes of Arkansas: Fayetteville, University of Arkansas Press, $536 \mathrm{p}$.

Schmitt, C.J., and Finger, S.E., 1987, The effects of sample preparation on measured concentrations of eight elements in edible fish tissues from streams contaminated by lead mining: Archives of Environmental Contaminants and Toxicology, v. 16, p. 185-207.

Smith, J.A., Witkowski, P.J., and Fusillo, T.V., 1988, Manmade organic compounds in the surface waters of the United States-A review of current understanding: U.S. Geological Survey Circular 1007, 92 p.

Sporstø1, S., Gjøs, N., Lichtenthaler, R.G., Gustavsen, K.O., Urdal, K., Oreld, F., and Skel, J., 1983, Source identification of aromatic hydrocarbons in sediments using GC/MS: Environmental Science and Technology, v. 17, no. 5, p. 282-286.

Swain, E.B., Engstrom, D.R., Brigham, M.E., Henning, T.A., and Brezonik, P.L., 1992, Increasing rates of atmospheric mercury deposition in midcontinental North America: Science, v. 257, p. 784-787.

U.S. Department of Agriculture, 1974, Farmers' use of pesticides in 1971-Quantities: U.S. Department of Agriculture, Economic Research Service, Agricultural Economic Report 252, 56 p.

U.S. Environmental Protection Agency, 1983, Analysis of the risks and benefits of seven chemicals used for subterranean termite control: Office of Pesticides and Toxic Substances, EPA 540/9-83-005.

1990, Suspended, canceled, and restricted pesticides: Office of Pesticides and Toxic Substances, EN-342.

1995, Water quality criteria summary tables: Office of Science and Technology.

U.S. Geological Survey, 1993, Standard operating procedure for the acid digestion of tissues sampled for trace metals determination: U.S. Geological Survey, National Water Quality Laboratory Standard Operating Procedure 1, $7 \mathrm{p}$.

1994, Standard operating procedure for the preparation of fish and Corbicula tissues for analysis of organochlorines (OCs), polychlorinated biphenyls (PCBs), and toxaphene: U.S. Geological Survey, National Water Quality Laboratory Standard Operating Procedure OT0026.0, 20 p.

Van Metre, P.C., and Callender, Edward, 1996, Identifying water-quality trends in the Trinity River, Texas, USA, 1969-1992, using sediment cores from Lake Livingston: Environmental Geology, v. 28, no. 4, p. 190-200.

1997, Water-quality trends in White Rock Creek Basin from 1912-1994 identified using sediment cores 
from White Rock Lake reservoir, Dallas, Texas: Journal of Paleolimnology, v. 17, p. 239-249.

Van Metre, P.C., Callender, Edward, and Fuller, C.C., 1997, Historical trends in organochlorine compounds in river basins identified using sediment cores from reservoirs: Environmental Science and Technology, v. 31, no. 8, p. 2,339-2,334.

Van Metre, P.C., Mahler, B.J., and Callender, Edward, 1997, Water-quality trends in the Rio Grande/Rio Bravo Basin using sediment cores from reservoirs: U.S. Geological Survey Fact Sheet FS-221-96, 8 p.

Van Metre, P.C., Mahler, B.J., and Furlong, E.T., 2000, Urban sprawl leaves its PAH signature: Environmental Science and Technology, v. 34, no. 19, p. 4,064-4,070.

Van Metre, P.C., Wilson, J.T., Callender, Edward, and Fuller, C.C., 1998, Similar rates of decrease of persistent, hydrophobic, and particle-reactive contaminants in riverine systems: Environmental Science and Technology, v. 32, no. 21, p. 3,312-3,317.
Verschueren, Karel, 1983, Handbook of environmental data on organic chemicals ( $2 \mathrm{~d}$ ed.): New York, Van Nostrand Reinhold, 1,310 p.

Ward, J.R., and Harr, C.A., eds., 1990, Methods for collection and processing of surface-water and bed-material samples for physical and chemical analyses: U.S. Geological Survey Open-File Report 90-140, 71 p.

Wershaw, R.L., Fishman, M.J., Grabbe, R.R., and Lowe, L.E., eds., 1987, Methods for the determination of organic substances in water and fluvial sediments: U.S. Geological Survey Techniques of Water-Resources Investigations, book 5, chap. A3, $80 \mathrm{p}$.

Whitmore, R.W., Kelly, J.E., Reading, P.L., Brandt, E., and Harris, T., 1992, National home and garden pesticide use survey-Executive summary, results, and recommendations: Research Triangle Park, N.C., Research Triangle Institute, Final report, RTI/5100/17-01F, 140 p. 
Table 7. Polycyclic aromatic hydrocarbon concentrations in stormwater suspended sediment samples

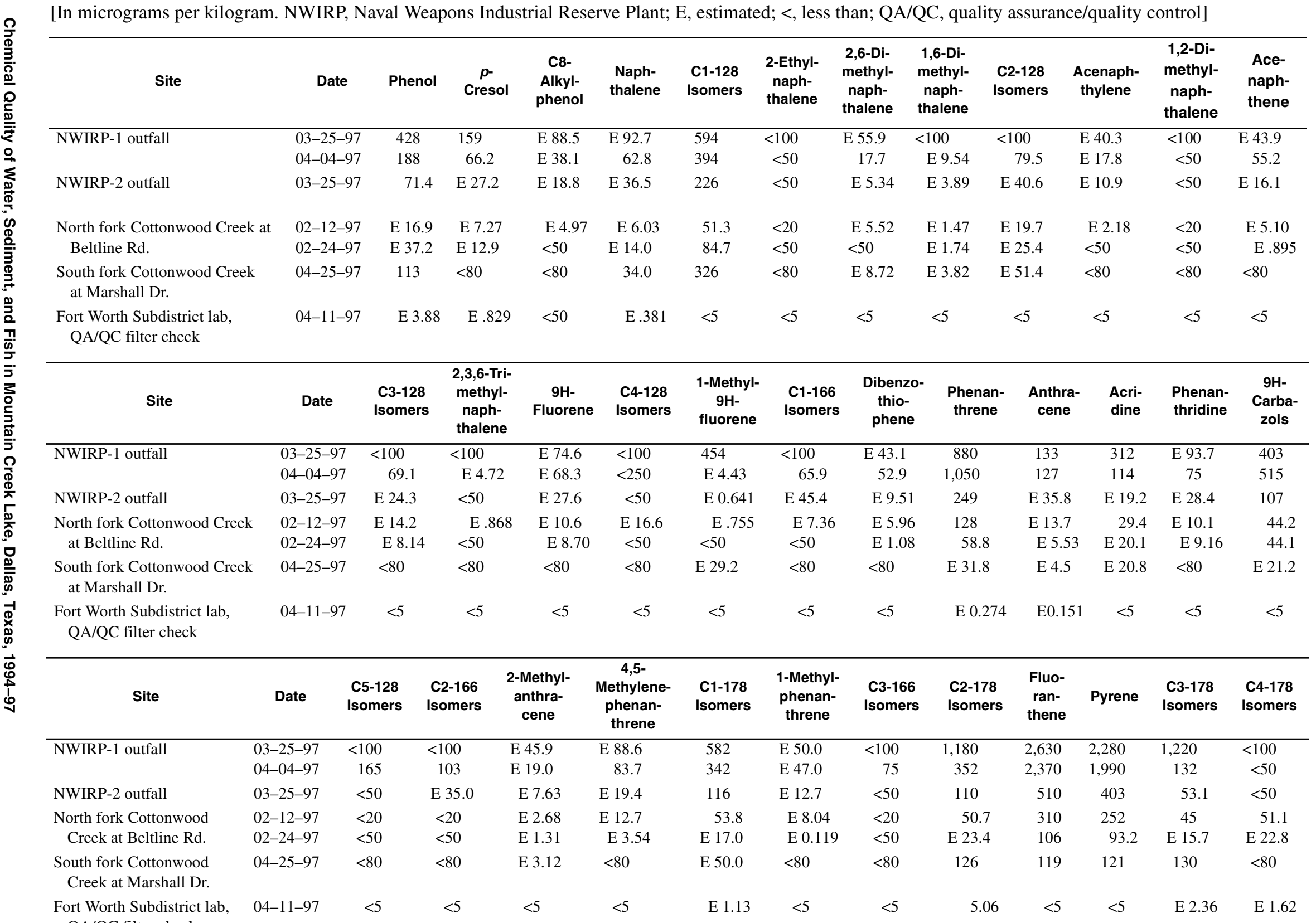


Table 7. Polycyclic aromatic hydrocarbon concentrations in stormwater suspended sediment samples—Continued

\begin{tabular}{|c|c|c|c|c|c|c|c|c|c|c|c|c|c|}
\hline Site & Date & $\begin{array}{l}\text { 1-Methyl- } \\
\text { pyrene }\end{array}$ & \multicolumn{2}{|c|}{$\begin{array}{l}\text { C1-202 } \\
\text { Isomers }\end{array}$} & $\begin{array}{l}\text { C2-202 } \\
\text { Isomers }\end{array}$ & $\begin{array}{l}\text { C5-178 } \\
\text { Isomers }\end{array}$ & $\begin{array}{l}\text { Benz(a)- } \\
\text { anthracene }\end{array}$ & Chrysene & $\begin{array}{l}\text { C3-202 } \\
\text { Isomers }\end{array}$ & $\begin{array}{l}\text { C1-228 } \\
\text { Isomers }\end{array}$ & $\begin{array}{l}\text { C4-202 } \\
\text { Isomers }\end{array}$ & $\begin{array}{l}\text { C5-202 } \\
\text { Isomers }\end{array}$ & $\begin{array}{l}\text { C2-228 } \\
\text { Isomers }\end{array}$ \\
\hline \multirow[t]{2}{*}{ NWIRP-1 outfall } & $03-25-97$ & 138 & \multicolumn{2}{|c|}{727} & 1,120 & $<100$ & 667 & 1,660 & 587 & 600 & $<100$ & $<100$ & $<500$ \\
\hline & 04-04-97 & 66.6 & \multicolumn{2}{|c|}{707} & 1,270 & $<50$ & 626 & 1,290 & 504 & 563 & 556 & 75.2 & 202 \\
\hline NWIRP-2 outfall & 03-25-97 & E 17.6 & \multicolumn{2}{|c|}{236} & 452 & $<50$ & 167 & 318 & 190 & 156 & 153 & $<50$ & 80.7 \\
\hline $\begin{array}{l}\text { North fork Cottonwood Creek } \\
\text { at Beltline Rd. }\end{array}$ & $\begin{array}{l}02-12-97 \\
02-24-97\end{array}$ & $\begin{array}{l}\text { E } 9.07 \\
\text { E } 1.31\end{array}$ & \multicolumn{2}{|c|}{$\begin{array}{l}105 \\
\text { E } 32.8\end{array}$} & $\begin{array}{c}169 \\
65.7\end{array}$ & $\begin{aligned} & 46.6 \\
< & 50\end{aligned}$ & $\begin{array}{r}93.4 \\
\text { E } 20.5\end{array}$ & $\begin{array}{l}192 \\
\text { E } 43.5\end{array}$ & $\begin{array}{r}55.0 \\
\text { E } 24.4\end{array}$ & $\begin{array}{r}57.9 \\
\text { E } 14.2\end{array}$ & $\begin{array}{r}63.8 \\
\text { E } 21.4\end{array}$ & $\begin{array}{l}\text { E } 17.3 \\
\text { E } 5.66\end{array}$ & $\begin{array}{l}27.4 \\
<50\end{array}$ \\
\hline $\begin{array}{l}\text { South fork Cottonwood Creek } \\
\text { at Marshall Dr. }\end{array}$ & 04-25-97 & E 2.02 & \multicolumn{2}{|c|}{ Е 38.6} & 131 & $<80$ & E 17.0 & E 70.0 & E 70.4 & E 40.8 & $<80$ & $<80$ & E 44.0 \\
\hline $\begin{array}{l}\text { Fort Worth Subdistrict lab, } \\
\text { QA/QC filter check }\end{array}$ & 04-11-97 & $<5$ & \multicolumn{2}{|c|}{$<5$} & $<5$ & $<5$ & $<5$ & $<5$ & $<5$ & $<5$ & $<5$ & $<5$ & $<5$ \\
\hline Site & Date & \multicolumn{2}{|c|}{$\begin{array}{l}\text { Benzo }(b)- \\
\text { fluoranthene }\end{array}$} & \multicolumn{2}{|c|}{$\begin{array}{l}\text { Benzo }(k)- \\
\text { fluoranthene }\end{array}$} & $\begin{array}{l}\text { Benzo(e)- } \\
\text { pyrene }\end{array}$ & $\begin{array}{l}\text { Benzo(a)- } \\
\text { pyrene }\end{array}$ & Perylene & $\begin{array}{l}\text { C1-252 } \\
\text { Isomers }\end{array}$ & $\begin{array}{l}\text { C3-228 } \\
\text { Isomers }\end{array}$ & $\begin{array}{l}\text { C2-252 } \\
\text { Isomers }\end{array}$ & $\begin{array}{l}\text { C4-228 } \\
\text { Isomers }\end{array}$ & $\begin{array}{l}\text { Benzo- } \\
(g, h, i)- \\
\text { perylene }\end{array}$ \\
\hline NWIRP-1 outfall & $\begin{array}{l}03-25-97 \\
04-04-97\end{array}$ & \multicolumn{2}{|l|}{$\begin{array}{l}2,490 \\
1,360\end{array}$} & \multicolumn{2}{|c|}{379} & $\begin{array}{r}1,250 \\
982\end{array}$ & $\begin{array}{r}1,030 \\
878\end{array}$ & $\begin{array}{l}209 \\
197\end{array}$ & $\begin{aligned}<550 \\
518\end{aligned}$ & $\begin{array}{l}<250 \\
\text { E } 23.9\end{array}$ & $\begin{array}{l}308 \\
274\end{array}$ & $\begin{array}{l}<100 \\
\text { E } 35.5\end{array}$ & $\begin{array}{r}1,360 \\
734\end{array}$ \\
\hline NWIRP-2 outfall & $03-25-97$ & \multicolumn{2}{|l|}{264} & & & 207 & 188 & Е 29.1 & 104 & E 2.96 & 77.4 & E 43.6 & 138 \\
\hline $\begin{array}{l}\text { North fork Cottonwood Creek } \\
\text { at Beltline Rd. }\end{array}$ & $\begin{array}{l}02-12-97 \\
02-24-97\end{array}$ & \multicolumn{2}{|l|}{$\begin{array}{l}185 \\
\text { E } 28.5\end{array}$} & & & $\begin{array}{l}137 \\
\text { E } 21.1\end{array}$ & $\begin{array}{l}126 \\
\text { E } 20.9\end{array}$ & $\begin{array}{l}26.9 \\
<50\end{array}$ & $\begin{array}{r}46.3 \\
\text { E } 10.0\end{array}$ & $\begin{array}{l}\text { E } 3.13 \\
<50\end{array}$ & $\begin{array}{l}\text { E } 15.8 \\
<50\end{array}$ & $\begin{array}{l}\text { E } 6.10 \\
<50\end{array}$ & $\begin{array}{c}104 \\
\text { E } 19.2\end{array}$ \\
\hline $\begin{array}{l}\text { South fork Cottonwood Creek } \\
\text { at Marshall Dr. }\end{array}$ & 04-25-97 & E 41.8 & & & 2.8 & E 20.8 & E 15.6 & $<80$ & E 16.72 & $<80$ & E 4.44 & $<80$ & E 23.4 \\
\hline $\begin{array}{l}\text { Fort Worth Subdistrict lab, } \\
\text { QA/QC filter check }\end{array}$ & 04-11-97 & $<5$ & & & & $<5$ & $<5$ & $<5$ & $<5$ & $<5$ & $<5$ & $<5$ & $<5$ \\
\hline Site & & te & $\begin{array}{c}\text { Inde } \\
(1,2,3 \\
\text { pyr }\end{array}$ & $\begin{array}{l}\text { no- } \\
\text {-c,d)- } \\
\text { ene }\end{array}$ & & $\begin{array}{l}\text { enzo( } a, h)- \\
\text { thracene }\end{array}$ & $\begin{array}{l}\text { C3-252 } \\
\text { Isomers }\end{array}$ & $\begin{array}{l}\text { C4- } \\
\text { Ison }\end{array}$ & $\begin{array}{l}252 \\
\text { ners }\end{array}$ & $\begin{array}{l}\text { C5-228 } \\
\text { Isomers }\end{array}$ & $\begin{array}{l}\text { C5-252 } \\
\text { Isomers }\end{array}$ & & Coronene \\
\hline NWIRP-1 outfall & $\begin{array}{ll}03- \\
04-\end{array}$ & $\begin{array}{l}5-97 \\
4-97\end{array}$ & $\begin{array}{r}1,16 \\
86\end{array}$ & & & $\begin{array}{l}171 \\
159\end{array}$ & $\begin{array}{r}<350 \\
57.9\end{array}$ & $\begin{array}{l}<35 \\
\mathrm{E} 2\end{array}$ & & $\begin{array}{r}<100 \\
<50\end{array}$ & $\begin{array}{r}<100 \\
<50\end{array}$ & & $\begin{array}{c}187 \\
91.7\end{array}$ \\
\hline NWIRP-2 outfall & $03-$ & 5-97 & 16 & & & E 32.1 & $<50$ & $<5$ & & $<50$ & $<50$ & & E 14.5 \\
\hline $\begin{array}{l}\text { North fork Cottonwood Creek at } \\
\text { Beltline Rd. }\end{array}$ & $\begin{array}{l}02- \\
02-\end{array}$ & $\begin{array}{l}2-97 \\
4-97\end{array}$ & $\begin{array}{r}12 \\
\mathrm{E} 2\end{array}$ & & & $\begin{array}{c}23.7 \\
\text { E } 3.03\end{array}$ & $\begin{array}{l}<20 \\
<50\end{array}$ & $\begin{array}{l}<2 \\
<5\end{array}$ & & $\begin{array}{l}<20 \\
<50\end{array}$ & $\begin{array}{l}<20 \\
<50\end{array}$ & & $\begin{array}{l}\text { E } 12.3 \\
\text { E } 1.19\end{array}$ \\
\hline $\begin{array}{l}\text { South fork Cottonwood Creek at } \\
\text { Marshall Dr. }\end{array}$ & 04 & $5-97$ & E 3 & & & $<80$ & $<80$ & $<8$ & & $<80$ & $<80$ & & $<80$ \\
\hline $\begin{array}{l}\text { Fort Worth Subdistrict lab, } \\
\text { QA/QC filter check }\end{array}$ & 04 & $1-97$ & $<$ & & & $<5$ & $<5$ & $<$ & 5 & $<5$ & $<5$ & & $<5$ \\
\hline
\end{tabular}


Table 8. Diagnostic polycyclic aromatic hydrocarbon ratios for selected surficial sediment samples

[Fluoranthene/pyrene ranges from 1.077 to $1.400 ; \mathrm{C}_{1}$-phenanthrene/phenanthrene ranges from 0.447 to 0.961 ; and phenanthrene + . . .T-PAH ranges from 2.292 to 4.153 for the main lake sites when the concentrations are greater than method detection limits. PAH, polycyclic aromatic hydrocarbon; NAS, Naval Air Station; NWIRP, Naval Weapons Industrial Reserve Plant; T-PAH, total polycyclic aromatic hydrocarbons]

\begin{tabular}{lcccc}
\hline \multicolumn{1}{c}{ Diagnostic PAH ratio } & \multicolumn{2}{c}{$\begin{array}{c}\text { Mean diagnostic } \\
\text { ratio in sediments } \\
\text { (standard deviation) }\end{array}$} & $\begin{array}{c}\text { Interpretation } \\
\text { guideline }\end{array}$ & Interpretation \\
\cline { 2 - 3 } & NAS & NWIRP & \\
\hline Fluoranthene/pyrene & $1.16(0.06)$ & $1.27(0.07)$ & $\begin{array}{c}\text { Pyrogenic sources } \\
\text { enriched in fluoranthene }\end{array}$ & $\begin{array}{c}\text { Both predominantly } \\
\text { pyrogenic; however, } \\
\text { NAS more fuel- } \\
\text { related than NWIRP }\end{array}$ \\
$\begin{array}{l}\text { 2- and 3-ringed compounds/ } \\
\text { 4- and 5-ringed compounds }\end{array}$ & $.59(.27)$ & $.35(.06)$ & $\begin{array}{c}\text { Fuel sources enriched in } \\
\text { di- and tri-cyclic species }\end{array}$ & Same \\
$\begin{array}{l}\mathrm{C}_{1} \text {-phenanthrene/phenanthrene } \\
\text { Phenanthrene + anthracene } \\
+\mathrm{C}_{1-3} \text { homologues/T-PAH } \\
(\mathrm{X} 100)\end{array}$ & $.75(.26)$ & $.45(.19)$ & $\begin{array}{c}\text { Fuel sources enriched in } \\
\text { alkylated homologues }\end{array}$ & Same \\
\hline
\end{tabular}

Table 9. Reported and estimated total polycyclic aromatic hydrocarbon concentrations for east and west lagoon sediment

[All samples from upper 60 centimeters; in micrograms per kilograms. PAHs, polycyclic aromatic hydrocarbons]

\begin{tabular}{ccc}
\hline Site no. & $\begin{array}{c}\text { Sum of reported PAHs } \\
\text { (EnSafe/Allen \& Hoshall, } \\
\text { 1996a) }\end{array}$ & $\begin{array}{r}\text { Estimated } \\
\text { total PAHs }\end{array}$ \\
\hline West lagoon \\
W01-S01 & 12,600 & 21,400 \\
W01-S02 & 128,000 & 189,000 \\
W01-S03 & 351,000 & 540,000 \\
W01-S04 & 77,800 & 139,000 \\
W01-S05 & 57,000 & 75,200 \\
& East lagoon & \\
W02-S01 & $3,070,000$ & $4,720,000$ \\
W02-S02 & 121,000 & 118,000 \\
W02-S03 & 88,200 & 115,000 \\
W02-S06 & 57,600 & 88,100 \\
\hline
\end{tabular}


Table 10. Organochlorine pesticide and polychlorinated biphenyl concentrations in stormwater suspended sediment samples

[In micrograms per kilogram. NWIRP, Naval Weapons Industrial Reserve Plant; <, less than; E, estimated; QA/QC, quality assurance/quality control]

\begin{tabular}{|c|c|c|c|c|c|c|c|c|c|c|}
\hline Site & Date & Lindane & $\begin{array}{l}\text { Hepta- } \\
\text { chlor }\end{array}$ & Aldrin & $\begin{array}{l}\text { Heptachlor } \\
\text { epoxide }\end{array}$ & $\begin{array}{l}\text { Chlor- } \\
\text { dane }\end{array}$ & $\begin{array}{l}\text { Endo- } \\
\text { sulfan I }\end{array}$ & Dieldrin & $\begin{array}{l}p, p^{\prime}- \\
\text { DDE }\end{array}$ & Endrin \\
\hline \multirow[t]{2}{*}{ NWIRP-1 outfall } & $03-25-97$ & $<7.0$ & $<7.0$ & $<7.0$ & $<7.0$ & $<70$ & $<7.0$ & $<7.0$ & $<7.0$ & $<7.0$ \\
\hline & 04-04-97 & $<3.8$ & $<3.8$ & $<3.8$ & $<3.8$ & $<38$ & $<3.8$ & $<3.8$ & $<3.8$ & $<3.8$ \\
\hline NWIRP-2 outfall & $03-25-97$ & $<2.0$ & $<2.0$ & $<2.0$ & $<2.0$ & $<20$ & $<2.0$ & $<2.0$ & $<2.0$ & $<2.0$ \\
\hline \multirow[t]{2}{*}{ North fork Cottonwood Creek at Beltline Rd. } & $02-12-97$ & $<.5$ & $<.5$ & $<.5$ & $<.5$ & 13 & $<.1$ & .96 & E.42 & $<.5$ \\
\hline & 02-24-97 & $<1.4$ & $<1.4$ & $<1.4$ & $<1.4$ & E11 & $<1.4$ & E1.3 & $<1.4$ & $<1.4$ \\
\hline South fork Cottonwood Creek at Marshall Dr. & $04-25-97$ & $<2.5$ & $<2.5$ & $<2.5$ & $<2.5$ & $<25$ & $<2.5$ & $<2.5$ & $<2.5$ & $<2.5$ \\
\hline Fort Worth Subdistrict lab, QA/QC filter check & 04-11-97 & $<2.5$ & $<2.5$ & $<2.5$ & $<2.5$ & $<25$ & $<2.5$ & $<2.5$ & $<2.5$ & $<2.5$ \\
\hline Site & Date & Perthane & $\begin{array}{l}p, p^{\prime} \\
\text { DDD }\end{array}$ & $\begin{array}{l}p, p^{\prime}- \\
\text { DDT }\end{array}$ & $\begin{array}{c}p, p '- \\
\text { Meth- } \\
\text { oxychlor }\end{array}$ & Mirex & $\begin{array}{l}\text { Toxa- } \\
\text { phene }\end{array}$ & $\begin{array}{c}\text { PCB } \\
\text { Aroclor } \\
1242\end{array}$ & $\begin{array}{c}\text { PCB } \\
\text { Aroclor } \\
1254\end{array}$ & $\begin{array}{l}\text { PCB } \\
\text { Aroclor } \\
1260\end{array}$ \\
\hline \multirow[t]{2}{*}{ NWIRP-1 outfall } & $03-25-97$ & $<70$ & $<7.0$ & $<7.0$ & $<55$ & $<7.0$ & $<700$ & $<70$ & 220 & 430 \\
\hline & 04-04-97 & $<38$ & $<4.8$ & $<3.8$ & $<31$ & $<3.8$ & $<380$ & $<38$ & 79 & 169 \\
\hline NWIRP-2 outfall & $03-25-97$ & $<20$ & $<2.0$ & $<2.8$ & $<16$ & $<2.0$ & $<200$ & $<22$ & E29 & E16 \\
\hline \multirow[t]{2}{*}{ North fork Cottonwood Creek at Beltline Rd. } & 02-12-97 & $<5.0$ & $<.6$ & .88 & $<4.0$ & $<.5$ & $<50$ & $<5.0$ & $<5.0$ & $<5.0$ \\
\hline & $02-24-97$ & $<14$ & $<1.4$ & E1.1 & $<11$ & $<1.4$ & $<140$ & $<14$ & $<14$ & $<14$ \\
\hline South fork Cottonwood Creek at Marshall Dr. & $04-25-97$ & $<25$ & $<2.5$ & $<2.5$ & $<20$ & $<2.5$ & $<250$ & $<25$ & $<25$ & $<25$ \\
\hline Fort Worth Subdistrict lab, QA/QC filter check & $04-11-97$ & $<25$ & $<2.5$ & $<2.5$ & $<20$ & $<2.5$ & $<250$ & $<25$ & $<25$ & $<25$ \\
\hline
\end{tabular}


Table 11. Summary of total polychlorinated biphenyl concentrations in sediment

[n, no. samples; $\mu \mathrm{g} / \mathrm{kg}$, micrograms per kilogram; NWIRP, Naval Weapons Industrial Reserve Plant; cm, centimeters; --, not sampled; ND, nondetections; NAS, Naval Air Station]

\begin{tabular}{|c|c|c|c|c|}
\hline \multirow{3}{*}{$\begin{array}{l}\text { Location } \\
\text { (depth interval for } \\
\text { bottom sediments; } n \text { ) }\end{array}$} & \multicolumn{4}{|c|}{$\begin{array}{c}\text { Total PCB concentrations } \\
(\mu \mathrm{g} / \mathrm{kg}) \\
\text { (mean concentration if } \mathrm{n} \geq 2 ; \pm 1 \text { standard deviation) }\end{array}$} \\
\hline & \multirow{2}{*}{$\begin{array}{l}\text { EnSafe/Allen } \\
\text { \& Hoshall } \\
\text { (1996a) }\end{array}$} & \multicolumn{3}{|c|}{ USGS } \\
\hline & & Phase I & Phase II & $\begin{array}{l}\text { Suspended } \\
\text { sediments }\end{array}$ \\
\hline \multicolumn{5}{|c|}{ NWIRP } \\
\hline West lagoon $(0-60 \mathrm{~cm} ; \mathrm{n}=5)$ & $5,600( \pm 5,400)$ & -- & -- & -- \\
\hline West lagoon outfall $(\mathrm{n}=2)$ & -- & -- & -- & ${ }^{1} 650,{ }^{1} 248$ \\
\hline East lagoon $(0-60 \mathrm{~cm} ; \mathrm{n}=6)$ & $760,720,4 \mathrm{ND}$ & -- & -- & -- \\
\hline East lagoon outfall $(\mathrm{n}=1)$ & -- & -- & -- & ${ }^{1} 45$ \\
\hline \multicolumn{5}{|c|}{ Cottonwood Bay, Creek, and Canal } \\
\hline Bay-13 (0-12 cm; $\mathrm{n}=1)$ & -- & 300 & -- & -- \\
\hline Bay-13 (51-58 cm; $\mathrm{n}=1)$ & -- & 3,500 & -- & -- \\
\hline MCL-7 (0-3 cm; n = 2) & -- & 110,800 & -- & -- \\
\hline MCL-7 (14-25 cm; n = 1) & -- & 2,000 & -- & -- \\
\hline East Cottonwood Bay $(0-3 \mathrm{~cm} ; \mathrm{n}=9)$ & -- & -- & $271( \pm 71)$ & -- \\
\hline Central Cottonwood Bay $(0-3 \mathrm{~cm} ; \mathrm{n}=9)$ & -- & -- & $313( \pm 146)$ & -- \\
\hline West Cottonwood Bay $(0-3 \mathrm{~cm} ; \mathrm{n}=4)$ & -- & -- & $119( \pm 90)$ & -- \\
\hline $\begin{array}{l}\text { North fork and south fork Cottonwood } \\
\text { Creek }(0-3 \mathrm{~cm} ; \mathrm{n}=2)\end{array}$ & -- & -- & $5.8,<3.0$ & -- \\
\hline Canal $(0-3 \mathrm{~cm} ; \mathrm{n}=4)$ & -- & -- & $29( \pm 15)$ & -- \\
\hline \multicolumn{5}{|c|}{ Mountain Creek Lake and NAS } \\
\hline Main lake $(0-3 \mathrm{~cm} ; \mathrm{n}=9)$ & -- & -- & $20( \pm 10)$ & -- \\
\hline Group 12 (Aroclor 1260) & $95,1,100$ & -- & -- & -- \\
\hline NAS inlet $(0-3 \mathrm{~cm} ; \mathrm{n}=6)$ & -- & -- & $226( \pm 272)$ & -- \\
\hline Runway inlet $(0-3 \mathrm{~cm} ; \mathrm{n}=2)$ & -- & -- & 224,118 & -- \\
\hline
\end{tabular}

${ }^{1}$ Sum of Aroclors 1254 and 1260; Aroclor 1242 not detected. 
Table 12. Estimated total and annual contaminant mass accumulations in east and central Cottonwood Bay

$[\mu \mathrm{g} / \mathrm{g}$, micrograms per gram; $\mu \mathrm{g} / \mathrm{kg}$, micrograms per kilogram; PAH, polycyclic aromatic hydrocarbon; PCB, polychlorinated biphenyl; kg, kilograms; kg/yr, kilograms per year]

\begin{tabular}{|c|c|c|c|c|c|c|c|}
\hline \multirow[t]{2}{*}{ Contaminant } & \multirow[t]{2}{*}{$\begin{array}{c}\text { Part of } \\
\text { Cottonwood } \\
\text { Bay }\end{array}$} & \multicolumn{2}{|c|}{$\begin{array}{c}\text { Mean contaminant } \\
\text { concentration in sediments } \\
\text { (metals } \mu \mathrm{g} / \mathrm{g} ; \\
\text { PAHs and PCBs, } \mu \mathrm{g} / \mathrm{kg} \text { ) }\end{array}$} & \multicolumn{2}{|c|}{$\begin{array}{l}\text { Total contaminant } \\
\text { mass accumulation } \\
(\mathbf{k g})\end{array}$} & \multicolumn{2}{|c|}{$\begin{array}{c}\text { Annual contaminant } \\
\text { mass accumulation } \\
(\mathrm{kg} / \mathrm{yr})\end{array}$} \\
\hline & & $1940-74$ & 1974-95 & $1940-74$ & $1974-95$ & $1940-74$ & 1974-95 \\
\hline \multirow[t]{2}{*}{ Chromium } & East & 2,420 & 240 & 67,000 & 820 & 2,000 & 39 \\
\hline & Central & 2,420 & 210 & 51,000 & 550 & 1,500 & 26 \\
\hline \multirow[t]{2}{*}{ Lead } & East & 128 & 90 & 3,500 & 310 & 100 & 15 \\
\hline & Central & 128 & 74 & 2,700 & 190 & 79 & 9.0 \\
\hline \multirow[t]{2}{*}{ Zinc } & East & 430 & 330 & 12,000 & 1,100 & 350 & 52 \\
\hline & Central & 430 & 350 & 9,000 & 910 & 260 & 43 \\
\hline \multirow[t]{2}{*}{ Total PAHs } & East & 40,000 & 26,000 & 1,100 & 89 & 32 & 4.2 \\
\hline & Central & 40,000 & 21,000 & 840 & 55 & 25 & 2.6 \\
\hline \multirow[t]{2}{*}{ Total PCBs } & East & 2,600 & 271 & 72 & .93 & 2.1 & .044 \\
\hline & Central & 2,600 & 313 & 55 & .82 & 1.6 & .039 \\
\hline
\end{tabular}

